$$
\begin{gathered}
\text { Universidade de São Paulo } \\
\text { Escola de Engenharia de São Carlos } \\
\text { Programa de Pós - Graduação em Engenharia Mecânica }
\end{gathered}
$$

\title{
EFEITO DA FERRO-OXIDAÇÃO A VAPOR ANTES E APÓS OPERAÇÃO DE USINAGEM NA RESISTÊNCIA AO DESGASTE DE FERRO SINTERIZADO
}

RAMIRO CARLOS GUIMARÃES

\begin{abstract}
Dissertação apresentada como parte dos requisitos para obtenção do Título de Mestre em Engenharia Mecânica
\end{abstract}

Orientador: Prof. Associado Dr. Luiz Carlos Casteletti

SÃO CARLOS - Abril 2008 


\section{AGRADECIMENTOS}

Ao Professor Associado Dr. Luiz Carlos Casteletti, orientador deste trabalho, pelas suas valiosas sugestões, coordenação, confiança, incentivo e inestimável colaboração durante a sua realização.

À Tecumseh do Brasil Ltda por proporcionar a oportunidade e contribuição de realizar o programa de mestrado.

À Escola de Engenharia de São Carlos e seus digníssimos professores, pelos ensinamentos.

À minha estimada esposa Márcia e filhos (Vitor e Natália) pelo apoio, compreensão e incentivo para a realização deste trabalho.

À todos aqueles que, direta ou indiretamente, colaboraram para concretização deste trabalho.

Agradeço especialmente a Deus. 


\section{SUMÁRIO}

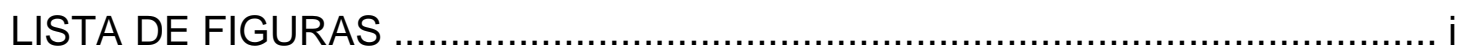

LISTA DE ABREVIATURAS, SIGLAS E SIMBOLOS ........................................ vii

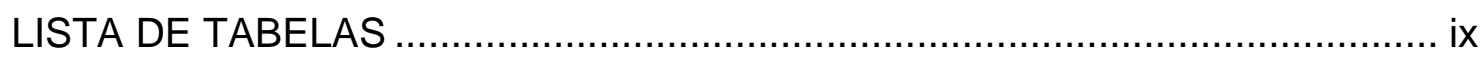

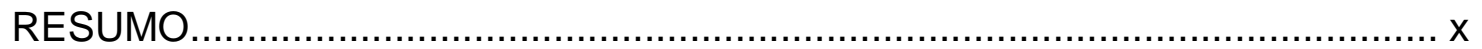

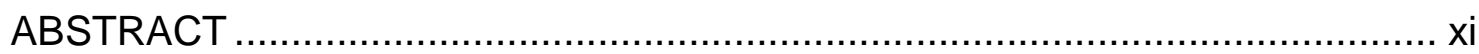

CAPÍTULO 1

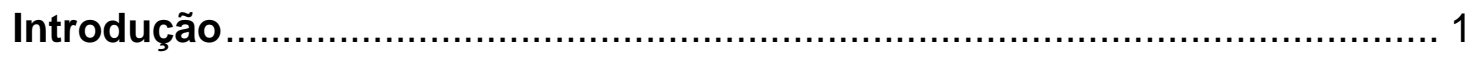

CAPÍTULO 2

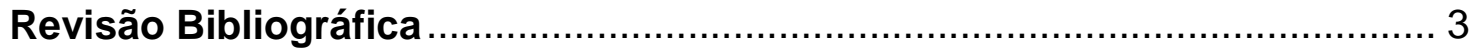

CAPÍTULO 3

Procedimentos Experimentais ................................................................ 23

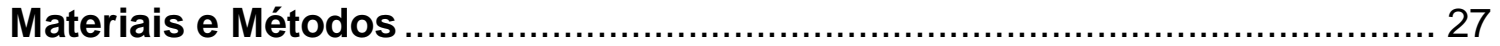

CAPÍTULO 4

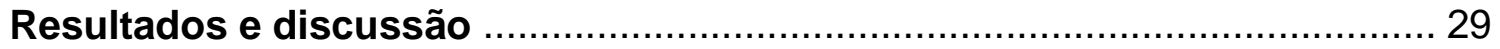

CAPÍTULO 5

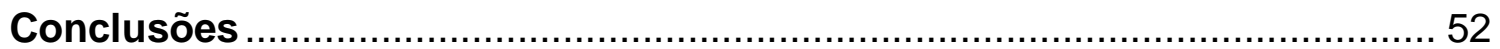

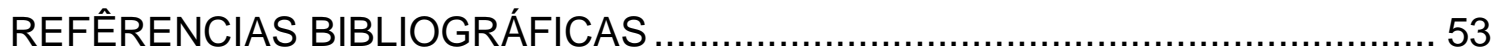




\section{LISTA DE FIGURAS}

Figura 1: Diagrama de equilíbrio entre $\mathrm{Fe} / \mathrm{Fe}_{3} \mathrm{O}_{4}$ em função da pressão parcial de $\mathrm{H}_{2} \mathrm{O}$ 8

Figura 2: Perfil de temperatura de peças ferro-oxidadas a $570{ }^{\circ} \mathrm{C}$ em um forno contínuo 9

Figura 3: Ciclo típico da oxidação a vapor de componentes sinterizados 10

Figura 4: Equipamento de desgaste. 14

Figura 5: Volume de desgaste em função da carga depois de deslizamento de $1000 \mathrm{~cm}$ 15

Figura 6: Espessura da camada em função da temperatura para dois níveis de densidade 17

Figura 7: Espessura da camada em função do tempo para dois níveis de temperatura 17

Figura 8: Mapa de desgaste dos aços esquemático mostrando as janelas ou regiões das condições tribológicas dos principais trabalhos com ligas ferrosas sinterizadas da literatura e os domínios dos mecanismos de desgaste predominantes em função da velocidade de deslizamento e da pressão normalizada 18

Figura 9: Gráfico da geometria da calota formada pelo ensaio de microdesgaste 
Figura 10: Diagramas esquemático de funcionamento do ensaio de microdesgaste com esfera livre e presa .22

Figura 11: Fluxograma do processo dos procedimentos experimentais. 23

Figura 12: Ilustração de um componente similar aplicado em um compressor hermético e seus respectivos mancais 24

Figura 13: Camada de óxido da biela realizada no Microscópio Óptico 27

Figura 14: Camada de óxido da amostra de teste realizada no Microscópio Óptico 29

Figura 15: Camada de óxido realizada no MEV 30

Figura 16: (a) curva de massa residual e de Temperatura em função do tempo e (b) curvas TG e DTG da amostra 1 32

Figura 17: (a) curvas de massa residual e de Temperatura em função do tempo e (b) curvas TG e DTG da amostra 2

Figura 18: comparação entre as curvas TG das amostras 1 e 2 34

Figura 19: Mancal da biela sem ferroxidação e com desgaste. 35

Figura 20: Mancal da biela ferroxidada sem desgaste 35

Figura 21: Gráfico de perfil da biela com desgaste 36

Figura 22: Gráfico de perfil da biela sem desgaste 36 
Figura 23: Gráfico de circularidade da biela com desgaste

Figura 24: Gráfico de circularidade da biela sem desgaste 38

Figura 25 e 26: Máquina de microdesgaste com esfera presa. 39

Figura 27: Aspecto da calota obtida no ensaio de microdesgaste com esfera presa (sem camada) com óleo e distância percorrida de 199,00 m

Figura 28: Aspecto da calota obtida no ensaio de microdesgaste com esfera presa (sem camada) com óleo e distância percorrida de 397,00 m 39

Figura 29: Aspecto da calota obtida no ensaio de microdesgaste com esfera presa (sem camada) com óleo e distância percorrida de 596,00 m 40

Figura 30: Aspecto da calota obtida no ensaio de microdesgaste com esfera presa (sem camada) com óleo e distancia percorrida de 794,00 m 40

Figura 31: Aspecto da calota obtida no ensaio de microdesgaste com esfera presa (com camada) com óleo e distância percorrida de 199,00 m 40

Figura 32: Aspecto da calota obtida no ensaio de microdesgaste com esfera presa (com camada) com óleo e distância percorrida de 397,00 m 40

Figura 33: Aspecto da calota obtida no ensaio de microdesgaste com esfera presa (com camada) com óleo e distância percorrida de 596,00 m 41

Figura 34: Aspecto da calota obtida no ensaio de microdesgaste com esfera presa (com camada) com óleo e distância percorrida de 794,00 m 41 
Figura 35: Gráfico do volume de desgaste $\left(\mathrm{mm}^{3}\right)$ realizado no teste microdesgaste com esfera presa tendo como lubrificante óleo

Figura 36: Máquina de microdesgaste com esfera solta

Figura 37: - Aspecto da calota obtida no ensaio de microdesgaste com esfera solta (sem camada) com óleo e distância percorrida de 80,00 m. 43

Figura 38: Aspecto da calota obtida no ensaio de microdesgaste com esfera solta (sem camada) com óleo e distância percorrida de 160,00 m 43

Figura 39: Aspecto da calota obtida no ensaio de microdesgaste com esfera solta (sem camada) com óleo e distância percorrida de 239,00 m 43

Figura 40: Aspecto da calota obtida no ensaio de microdesgaste com esfera solta (sem camada) com óleo e distância percorrida de 319,00 m 43

Figura 41: Aspecto da calota obtida no ensaio de microdesgaste com esfera solta (com camada) com óleo e distância percorrida de 80,00 m 43

Figura 42: Aspecto da calota obtida no ensaio de microdesgaste com esfera solta (com camada) com óleo e distância percorrida de 160,00 m 44

Figura 43: Aspecto da calota obtida no ensaio de microdesgaste com esfera solta (com camada) com óleo e distância percorrida de 239,00 m 44

Figura 44: Aspecto da calota obtida no ensaio de microdesgaste com esfera solta (com camada) com óleo e distância percorrida de 319,00 m 44

Figura 45: Gráfico do volume de desgaste $\left(\mathrm{mm}^{3}\right)$ realizado no ensaio de microdesgaste com esfera solta e lubrificante (óleo) 45 
Figura 46: Aspecto da calota obtida no ensaio de microdesgaste com esfera solta (sem camada) Alumina $1 \mu \mathrm{m}$ e distância percorrida de 80,00 m 46

Figura 47: Aspecto da calota obtida no ensaio de microdesgaste com esfera solta (sem camada) Alumina $1 \mu \mathrm{m}$ e distância percorrida de 160,00 m 46

Figura 48: Aspecto da calota obtida no ensaio de microdesgaste com esfera solta (sem camada) Alumina $1 \mu \mathrm{m}$ e distância percorrida de 239,00 m 46

Figura 49: Aspecto da calota obtida no ensaio de microdesgaste com esfera solta (sem camada) Alumina $1 \mu \mathrm{m}$ e distância percorrida de 319,00 m 46

Figura 50: Aspecto da calota obtida no ensaio de microdesgaste com esfera solta (com camada) Alumina $1 \mu \mathrm{m}$ e distância percorrida de $80,00 \mathrm{~m}$ 47

Figura 51: Aspecto da calota obtida no ensaio de microdesgaste com esfera solta (com camada) Alumina $1 \mu \mathrm{m}$ e distância percorrida de 160,00 m 47

Figura 52: Aspecto da calota obtida no ensaio de microdesgaste com esfera solta (com camada) Alumina $1 \mu \mathrm{m}$ e distância percorrida de 239,00 m 47

Figura 53 Aspecto da calota obtida no ensaio de microdesgaste com esfera solta (com camada) Alumina $1 \mu \mathrm{m}$ e distância percorrida de $319,00 \mathrm{~m}$ 47

Figura 54: Gráfico do volume de desgaste $\left(\mathrm{mm}^{3}\right)$ realizado no teste de microdesgaste com esfera solta e abrasivo (Alumina $1 \mu \mathrm{m}$ ) 48

Figura 55: Aspecto da calota obtida no ensaio de microdesgaste com esfera solta (sem camada) Alumina $5 \mu \mathrm{m}$ e distância percorrida de $80,00 \mathrm{~m}$ 49 
Figura 56: Aspecto da calota obtida no ensaio de microdesgaste com esfera solta (sem camada) Alumina 5 um e distância percorrida de 160,00 m 49

Figura 57: Aspecto da calota obtida no ensaio de microdesgaste com esfera solta (sem camada) Alumina 5 um e distância percorrida de 239,00 m 49

Figura 58: Aspecto da calota obtida no ensaio de microdesgaste com esfera solta (sem camada) Alumina 5 um e distância percorrida de 319,00 m 49

Figura 59: Aspecto da calota obtida no ensaio de microdesgaste com esfera solta (com camada) Alumina $5 \mu \mathrm{m}$ e distância percorrida de $80,00 \mathrm{~m}$ 50

Figura 60: Aspecto da calota obtida no ensaio de microdesgaste com esfera solta (com camada) Alumina $5 \mu \mathrm{m}$ e distância percorrida de 160,00 m 50

Figura 61: Aspecto da calota obtida no ensaio de microdesgaste com esfera solta (com camada) Alumina 5 um e distância percorrida de 239,00 m 50

Figura 62: Aspecto da calota obtida no ensaio de microdesgaste com esfera solta (com camada) Alumina 5 m e distância percorrida de 319,00 m 50

Figura 63: Gráfico do volume de desgaste $\left(\mathrm{mm}^{3}\right)$ realizado no teste microdesgaste com esfera solta e abrasivo (Alumina $5 \mu \mathrm{m}$ ) 


\section{LISTA DE ABREVIATURAS, SIGLAS E SÍMBOLOS.}

\begin{tabular}{|c|c|}
\hline $\mathrm{g} / \mathrm{cm}^{3}$ & Gramas por Centímetro Cúbico \\
\hline$\mu \mathrm{m}$ & Micro-metro \\
\hline$\stackrel{\circ}{C}$ & Grau Celsius \\
\hline Kgf & Quilograma Força \\
\hline gf & Grama Força \\
\hline $\mathrm{cm}^{3}$ & Centímetro Cúbico \\
\hline $\mathrm{H}_{2} \mathrm{O}$ & Água \\
\hline $\mathrm{Fe}_{2} \mathrm{O}_{3}$ & Hematita \\
\hline $\mathrm{Fe}_{3} \mathrm{O}_{4}$ & Magnetita \\
\hline $\mathrm{H}_{2}$ & Hidrogênio \\
\hline $\mathrm{FeO}$ & Wustita \\
\hline $\mathrm{m}^{3} / \mathrm{h}$ & Metro Cúbico por Hora \\
\hline $\mathrm{OH}$ & Hidróxido de Oxigênio \\
\hline $\mathrm{Kg} / \mathrm{h}$ & Quilograma por Hora \\
\hline $\mathrm{Fe}-\mathrm{Cu}$ & Ferro Cobre \\
\hline $\mathrm{Fe}$ & Ferro \\
\hline $\mathrm{Cu}$ & Cobre \\
\hline $\mathbf{C}$ & Carbono \\
\hline $\mathrm{Kg}$ & Quilograma \\
\hline $\mathrm{cm} / \mathrm{s}$ & Centímetro por Segundo \\
\hline cm & Centímetro \\
\hline HRB & Dureza Rockwell Escala B \\
\hline $\min$ & Minutos \\
\hline$\stackrel{\circ}{ } \mathrm{C} / \mathrm{min}$ & Grau Celsius por Minuto \\
\hline $\mathrm{L} / \mathrm{min}$ & Litros por Minuto \\
\hline $\mathbf{N}_{2}$ & Nitrogênio \\
\hline $\mathrm{Fe}(\mathrm{OH})_{3}$ & Hidróxido de Ferro \\
\hline $\mathrm{O}_{2}$ & Oxigênio \\
\hline h & Horas \\
\hline
\end{tabular}




$\begin{array}{ll}\mathbf{m} / \mathbf{s} & \text { Metros por Segundo } \\ \% & \text { Porcentagem } \\ \mathbf{M g} \cdot \mathbf{m}^{-3} & \text { Miligrama por Metro Cúbico } \\ \mathbf{T G} & \text { Curva Termogravimétrica } \\ \mathbf{D T G} & \text { Derivada da Curva Termogravimétrica } \\ \mathbf{N} & \text { Newton } \\ \mathbf{P O E} & \text { Poliol Oil Ester } \\ \mathbf{c S t} & \text { Centistokes } \\ \mathbf{m} & \text { Metro } \\ \mathbf{m m} & \text { Milímetros Cúbico } \\ \mathbf{m m} & \text { Milímetros } \\ \mathbf{M P a}^{3} & \text { Mega Pascal } \\ \mathbf{N a C l}^{\mathbf{m}} & \text { Cloreto de Sódio } \\ \mathbf{H}_{\mathbf{2}} \mathrm{SO}_{\mathbf{4}} & \text { Ácido Sulfúrico } \\ \mathbf{A l} \mathbf{O}_{3} & \text { Alumina } \\ \mathbf{H V} & \text { Dureza Vickers }\end{array}$




\section{LISTA DE TABELAS}

Tabela 1: Dureza do substrato (amostra sem a camada ferroxidada)...... 28

Tabela 2: Microdureza da amostra com a camada ferroxidada ...... 29

Tabela 3: Resumo da composição das amostras 1 e 2 após testes de termogravimetria 32 


\section{RESUMO}

GUIMARÃES, R.C. (2008). Efeito da ferro-oxidação a vapor antes e após operação de usinagem na resistência ao desgaste de ferro sinterizado. Dissertação (Mestrado) Escola de Engenharia de São Carlos, Universidade de São Paulo, São Carlos, 2008.

Neste trabalho verificou-se o efeito da ferroxidação a vapor, aplicada antes e após operações de usinagem de acabamento final, na resistência ao desgaste de um ferro sinterizado, utilizado na fabricação de bielas usadas em mancais de deslizamento de compressor hermético. Ensaios micrográficos, de dureza e microdureza, ensaios de perfil e circularidade, testes de vida acelerados em um compressor hermético doméstico de refrigeração e ensaios de microdesgaste, usando-se o mesmo tipo de óleo aplicado em compressores, ou abrasivos com diferentes granulometrias, foram realizados em peças e amostras com e sem a camada ferroxidada. Verificou-se que a camada ferroxidada apresentou valores de durezas superiores ao do substrato em $130 \%$. No caso das amostras ferroxidadas, os resultados indicaram significativa melhora na resistência ao desgaste tanto no teste de aplicação direta no compressor, demonstrado nos testes de perfis e de circularidades, como nos ensaios de microdesgaste, evidenciando a grande efetividade desse tratamento no aumento da resistência ao desgaste nas condições testadas neste trabalho.

Palavras-chave: Desgaste; Ferro sinterizado; Usinagem; Tratamento a vapor. 


\begin{abstract}
GUIMARÃES, R.C. (2008). Effect of steam treatment before and after machining operation on wear resistance of sintered steel. Dissertation (Master's Degree) - Escola de Engenharia de São Carlos, Universidade de São Paulo, São Carlos, 2008.

The intent of this work was to verify the effect of steam treatment applied before and after finishing machining operations on wear resistance of sintered steel used in the manufacturing of connecting rod applied in sliding bearings of hermetic compressor. Micrographic tests, hardness and micro hardness, test profile and roundness, accelerated endurance test in domestic refrigeration hermetic compressor and micro wear test using the same oil used in the compressor or abrasive with different grain size were made on parts and samples with and without oxide layer. It was verified that the oxide layer indicated hardness values over $130 \%$ than that of the substrate. In the case of layer oxide, the results showed significant improvement on wear resistance in the direct compressor application shown by test profile and roundness as well as micro wear test, showing the high efficiency of treatment increasing the wear resistance in the conditions tested in this work.
\end{abstract}

Key words: Wear; Sintered steel; Machining; Steam treatment 


\section{CAPÍTULO 1}

\section{INTRODUÇÃO}

O processo de ferro-oxidação a vapor (steam treatment, steam oxidation, steam blacking) é um processo de acabamento final de peças sinterizadas e tem sido usado há mais de 40 anos, para o melhoramento das características das mesmas.

A ferro-oxidação a vapor é um recobrimento termoquímico da classe dos recobrimentos de conversão química. O seu principal objetivo é produzir uma camada de magnetita em todas as superfícies exteriores e, também, dentro da rede de poros interconectados dos componentes. Isto melhora a aparência de peças produzidas com aços e ferros fundidos, influindo positivamente na resistência ao desgaste e a corrosão.

O processo consiste em submeter às peças a um fluxo de vapor de água superaquecido, formando-se uma camada de óxido de ferro nas paredes da rede de poros interconectados, bem como na superfície externa da peça (tipicamente uma camada de aproximadamente 2 a $7 \mu \mathrm{m}$ de óxido). A camada oxidada obtida desta forma é muito aderente e menos propensa a defeitos, como trincas e bolhas, em comparação com camadas oxidadas formadas ao ar.

O processo é aplicado geralmente em peças de aço sinterizadas com densidade na faixa de 5,4 a $7,0 \mathrm{~g} / \mathrm{cm}^{3}$. Nestas peças, existe uma rede de poros conectados, de forma que o fluxo gasoso pode passar através de toda sua seção.

$O$ processo requer investimento de capital relativamente baixo, resultando num baixo custo de tratamento por peça.

Apesar do uso extensivo dos componentes ferrosos produzidos pela metalurgia do pó em situações de deslizamento, existem poucos trabalhos referentes ao seu comportamento tribológico e no caso dos componentes ferrosos sinterizados oxidados a vapor, existem ainda menos trabalhos referentes ao seu comportamento tribológico.

Os principais benefícios decorrentes do processo de ferro-oxidação a vapor são: 
- Aumentos da dureza acima de $100 \%$ podem ser obtidos, dependendo do processo e condições aplicados.

- Aumento da resistência à compressão de até $25 \%$.

- Aumento da resistência à corrosão.

- Melhoramento da resistência ao desgaste,

- Selamento da porosidade, dando estanqueidade à peça, tornando-as impermeáveis a gases e líquidos.

- O aumento dimensional em função da camada de óxido não é problemático.

- A peça fica recoberta com uma cor azul escuro, resultando numa ótima aparência.

- Processo de baixo custo e alta produtividade.

O objetivo do presente trabalho consistiu na avaliação do efeito da ferroxidação a vapor, antes e após, operação de usinagem na resistência ao desgaste de um ferro sinterizado utilizado na fabricação de bielas. 


\section{CAPÍTULO 2}

\section{REVISÀO BIBLIOGRÁFICA}

A Metalurgia do pó consiste num processo altamente desenvolvido de manufatura de peças metálicas ferrosas e não ferrosas.

Basicamente, os pós-metálicos são configurados em ferramental apropriado, com posterior aquecimento sob condições controladas, em temperaturas abaixo do ponto de fusão do metal base, para promover ligações metalúrgicas entre as partículas.

Esse aquecimento, denominado sinterização, normalmente confere à massa de pó aglomerada as propriedades físicas e mecânicas desejadas. Na sinterização a economia de material é levada ao extremo: não ocorre a geração de cavacos os quais numa usinagem convencional podem representar até $50 \%$ do peso original da peça bruta e tendo ainda vantagem de controlar a densidade. Mesmo levando-se em consideração à necessidade de operações posteriores de usinagem, uma peça sinterizada normal, mantém acima de $97 \%$ de sua massa original.

Tratamentos térmicos e termoquímicos podem ser usados nas peças sinterizadas de ferro para se obter aumento de resistência à tração, ao desgaste e dureza, ou uma boa combinação entre elas.

Os tratamentos usuais a que podem ser submetidas às peças sinterizadas incluem a têmpera, cementação, carbonitretação, nitretação e tratamento a vapor. A seleção do tratamento a ser feito depende basicamente da aplicação e da densidade da peça.

Têmpera - toda peça sinterizada, da mesma maneira que as forjadas, podem ser temperadas. A têmpera é efetuada de forma similar a dos aços convencionais, tendo como ressalva o tipo de atmosfera protetora e evitando-se os banhos de sal, que tendem a provocar corrosão pela retenção do sal nos poros da peça. Para se evitar distorção muito acentuada, pode-se aumentar a temperatura do óleo até em torno de $150^{\circ} \mathrm{C}$.

Cementação - Peças sinterizadas com baixo teor de carbono $(0,1$ a $0,2 \%)$ podem ser cementadas por cementos convencionais ou gasosos. Cementos líquidos não são recomendados, devido à dificuldade de limpeza da peça, isentando-a do sal do banho. 
Os cementos sólidos, por motivos econômicos não são utilizados em peças sinterizadas pequenas, produzidas em grandes quantidades. Os cementos gasosos são os mais recomendados. Para se ter uma peça cementada com razoável homogeneidade de camada e dureza é necessário uma densidade mínima de 7,2 $\mathrm{g} / \mathrm{cm}^{3}$.

Carbonitretação - É uma forma modificada de cementação que consiste na introdução de amônia na atmosfera gasosa. O nitrogênio contido na amônia difunde na superfície da peça, simultaneamente, com o carbono. A carbonitretação é feita com temperatura mais baixa (pelo menos $55^{\circ} \mathrm{C}$ ) e tempo inferior ao de cementação.

Nitretação - difere da carbonitretação principalmente no fato de que a temperatura usada situa-se no campo de fase ferrítica (cerca de $500^{\circ} \mathrm{C}$ ).

Tratamento a vapor - O processo consiste na produção de uma camada de óxido aderente na superfície e nos poros interconectados de uma peça sinterizada, o que resulta num melhoramento geral nas características das peças, tais como aumento de dureza e densidade, maior resistência à compressão, resistência à corrosão e ao desgaste e o fechamento acentuado dos poros presentes. É um processo limpo, seguro e eficiente em termos de custo, principalmente quando se tratam de peças com formas complexas, tolerâncias dimensionais rigorosas e grandes lotes de produção.

Os mancais auto lubrificantes são um tipo clássico de componente produzido utilizando-se a técnica de metalurgia do pó, uma vez que a porosidade existente num mancal sinterizado pode ser preenchida com óleo para garantir uma lubrificação permanente entre o eixo e o mancal. A maioria das peças sinterizadas pesa menos de $2,5 \mathrm{~kg}$, embora peças com até $15 \mathrm{~kg}$, possam ser fabricadas.

Inicialmente, produzia-se com a metalurgia do pó apenas peças com formas geométricas simples. Atualmente, com o desenvolvimento tecnológico do processo consegue-se produzir peças com formatos complexos a um custo muito inferior ao dos processos convencionais de conformação, devido ao seu baixo consumo de energia, alto aproveitamento do material e baixo custo de investimento.

O processo da metalurgia do pó é largamente empregado para produzir peças e componentes cujas superfícies estão sujeitas ao contato por deslizamento e/ou rolamento em serviço, tais como mancais de deslizamento, engrenagens, excêntricos, eixos e peças de compressores. Aços produzidos pela metalurgia do pó encontram amplas aplicações na indústria automobilística, em sistemas de 
transmissão e motores, principalmente para componentes sujeitos ao desgaste (WANG; DANNINGER, 1998).

As tensões operacionais admissíveis dos materiais produzidos pela metalurgia do pó são inferiores as dos materiais fundidos, devido à presença da porosidade, a qual reduz a sua resistência.

O desempenho das peças quanto ao desgaste pode ser melhorado pelo uso da Engenharia de Superfície, que visa à produção de materiais compósitos em que substrato e recobrimento e/ou modificação de superfícies proporcionem desempenho superior ao que poderia ser obtido por quaisquer destas partes individualmente. Além de buscar o desenvolvimento de tecnologias de recobrimentos e modificação de superfícies, pesquisadores atuando nesta área buscam otimizar o compósito que será formado (RICKERBY; MATTHEWS, 1991).

Basicamente, existem dois objetivos comuns no uso da Engenharia de Superfície para aplicações tribológicas: o aumento da resistência ao desgaste e a modificação do comportamento do atrito. Em alguns casos, alcançam-se ambos objetivos simultaneamente. Isto se consegue pela mudança das características estruturais ou da composição das superfícies das peças e componentes de engenharia através da aplicação de tecnologias de superfície tradicionais e inovadoras. (HUTCHINGS, 1992).

Freqüentemente, peças e componentes de engenharia são projetados sem consideração quanto aos tratamentos superficiais que serão posteriormente aplicados. Mas, idealmente, a Engenharia de Superfície envolve o projeto do componente com o conhecimento prévio do tratamento superficial a ser empregado (BELL, 1991).

Dentre os processos disponíveis para o tratamento superficial de peças produzidas pela metalurgia do pó, destaca-se a ferro-oxidação a vapor, que é um processo de recobrimento termoquímico pertencente à categoria dos recobrimentos de conversão química. Este processo de deposição é uma técnica mista, no qual recobrimentos não metálicos são produzidos pela transformação das camadas atômicas exteriores da superfície de um metal em óxidos do mesmo, com propriedades diferentes da superfície original. Isto é efetuado por meio de uma reação induzida em um ambiente artificial por meio do qual o metal original forma um dos elementos do composto com os outros elementos sendo fornecidos pelo ambiente. Deste modo, são obtidos recobrimentos com uma interface sem 
descontinuidade e, devido a isso, apresentam uma boa adesão ao substrato (BHUSHAN; GUPTA, 1991).

Os recobrimentos óxidos decorrentes de conversão química de ligas ferrosas podem produzir significativos aumentos de desempenho tribológico em componentes (YOUNG, 1985). Esses recobrimentos são extensivamente usados em aplicações que necessitam de resistência ao desgaste moderado, além de também serem usados onde se necessita de resistência à corrosão (BHUSHAN; GUPTA, 1991).

Quando a espessura da camada de óxido no interior da rede de poros interconectados aumenta, os diâmetros dos poros diminuem até que alguns poros sejam completamente preenchidos com óxidos. Isso causa, a partir de uma determinada etapa, o fechamento dessa rede de poros e torna o componente impermeável aos líquidos e gases.

A oxidação a vapor de componentes sinterizados produz uma camada de óxido com espessura de até $7 \mu \mathrm{m}$ em todas as superfícies exteriores e também dentro da rede de poros interconectados, em uma extensão que depende das condições da oxidação (FRANKLIN; DAVIES, 1977; RAZAVIZADEH; DAVIES, 1979; BINDER, 1996).

O objetivo do processo de tratamento a vapor é criar uma camada de magnetita $\left(\mathrm{Fe}_{3} \mathrm{O}_{4}\right)$ na superfície e na rede de poros comunicantes das peças ferrosas sinterizadas. Um óxido intermediário, a wustita ( $\mathrm{FeO})$ é estável somente a acima de $570^{\circ} \mathrm{C}$. Acima do ponto de ebulição da água $\left(100^{\circ} \mathrm{C}\right)$ e abaixo de $570{ }^{\circ} \mathrm{C}$, a reação do vapor d' água com o ferro para formar o $\mathrm{Fe}_{3} \mathrm{O}_{4}$ é:

$3 \mathrm{Fe}+4 \mathrm{H}_{2} \mathrm{O}$ (gás) $\leftrightarrow \mathrm{Fe}_{3} \mathrm{O}_{4}+4 \mathrm{H}_{2}$ (gás) reação (1)

Esta reação de dissociação do vapor d'água e formação da magnetita são acompanhadas pela liberação de calor (reação exotérmica), quando esta ocorre na temperatura de $527^{\circ} \mathrm{C}$, ou seja, na faixa de temperat ura usual do tratamento.

Se a temperatura e a atmosfera não forem corretas pode ocorrer à interferência de duas reações concorrentes:

1) Se a temperatura estiver abaixo de $100^{\circ} \mathrm{C}$, a águ a líquida pode reagir com o ferro e formar o hidróxido $\mathrm{Fe}(\mathrm{OH})_{3}$ de acordo com:

$6 \mathrm{H}_{2} \mathrm{O}$ (líq.) $+2 \mathrm{Fe} \leftrightarrow 2 \mathrm{Fe}(\mathrm{OH})_{3}+3 \mathrm{H}_{2}$ (gás) reação (2) 
Este hidróxido pode se transformar em hematita, $\mathrm{Fe}_{2} \mathrm{O}_{3}$ de acordo com:

$$
2 \mathrm{Fe}(\mathrm{OH})_{3} \leftrightarrow \mathrm{Fe}_{2} \mathrm{O}_{3}+\mathrm{H}_{2} \text { (gás). }
$$

2) Acima de $427^{\circ} \mathrm{C}$, outra reação concorrente é favo recida, a qual também leva a hematita de acordo com:

$$
2 \mathrm{H}_{2} \mathrm{O} \text { (gás) } \leftrightarrow 2 \mathrm{OH} \text { (gás) }+\mathrm{H}_{2} \text { (gás) }
$$

A hidroxila $(\mathrm{OH})$ resultante reage com o ferro produzindo o hidróxido $\mathrm{Fe}(\mathrm{OH})_{3}$, que pode se decompor em hematita, conforme a Reação (3).

Quando o forno é purgado e não há presença de ar acima de $315^{\circ} \mathrm{C}$, o vapor reage de acordo com uma rota intermediária preferencial:

$2 \mathrm{H}_{2} \mathrm{O}$ (gás) $\leftrightarrow \mathrm{O}_{2}$ (gás.) $+2 \mathrm{H}_{2}$ (gás) reação (5)

$\mathrm{E} \circ \mathrm{O}_{2}$ (gás) estará disponível para reagir com o ferro para formar a magnetita:

$2 \mathrm{O}_{2}$ (gas.) $+3 \mathrm{Fe} \leftrightarrow \mathrm{Fe}_{3} \mathrm{O}_{4}$ reação (6)

A reação (1) é a soma da reação (5) e da reação (6).

A reação de equilíbrio da reação (1) é dada pela constante:

$\mathrm{K}=\mathrm{p}\left(\mathrm{H}_{2} \mathrm{O}\right) / \mathrm{p}\left(\mathrm{H}_{2}\right)$, onde:

$\mathrm{p}\left(\mathrm{H}_{2} \mathrm{O}\right)=$ pressão parcial do vapor d'água.

$p\left(\mathrm{H}_{2}\right)=$ pressão parcial do hidrogênio.

$\mathrm{Na}$ figura 1 estão representadas as faixas de temperaturas de estabilidade dos óxidos de ferro, em função do valor da constante $\mathrm{K}$.

Até a temperatura de $570^{\circ} \mathrm{C}$, a camada de óxido consi ste principalmente de $\mathrm{Fe}_{3} \mathrm{O}_{4}$; acima desta temperatura pode ser produzido $\mathrm{FeO}$, que cresce mais rapidamente do que outros óxidos, devido sua estrutura cristalina; este óxido se decompõe euteticamente durante o resfriamento resultando em uma estrutura dupla 
de $\mathrm{Fe}_{3} \mathrm{O}_{4}$ e $\mathrm{Fe}$.

A proporção dos dois óxidos $\left(\mathrm{Fe}_{3} \mathrm{O}_{4}\right.$ e $\left.\mathrm{Fe}\right)$ na camada resultante depende da taxa de resfriamento, que, sendo alta, gera maior retenção de $\mathrm{FeO}$, resultando numa camada com uma estrutura tripla $\mathrm{Fe}_{3} \mathrm{O}_{4}, \mathrm{FeO}$ e $\mathrm{Fe}$. Estas estruturas não são desejadas por terem uma resistência à corrosão inferior as das camadas produzidas abaixo de $570{ }^{\circ} \mathrm{C}$, ou seja, a magnetita $\left(\mathrm{Fe}_{3} \mathrm{O}_{4}\right)$.

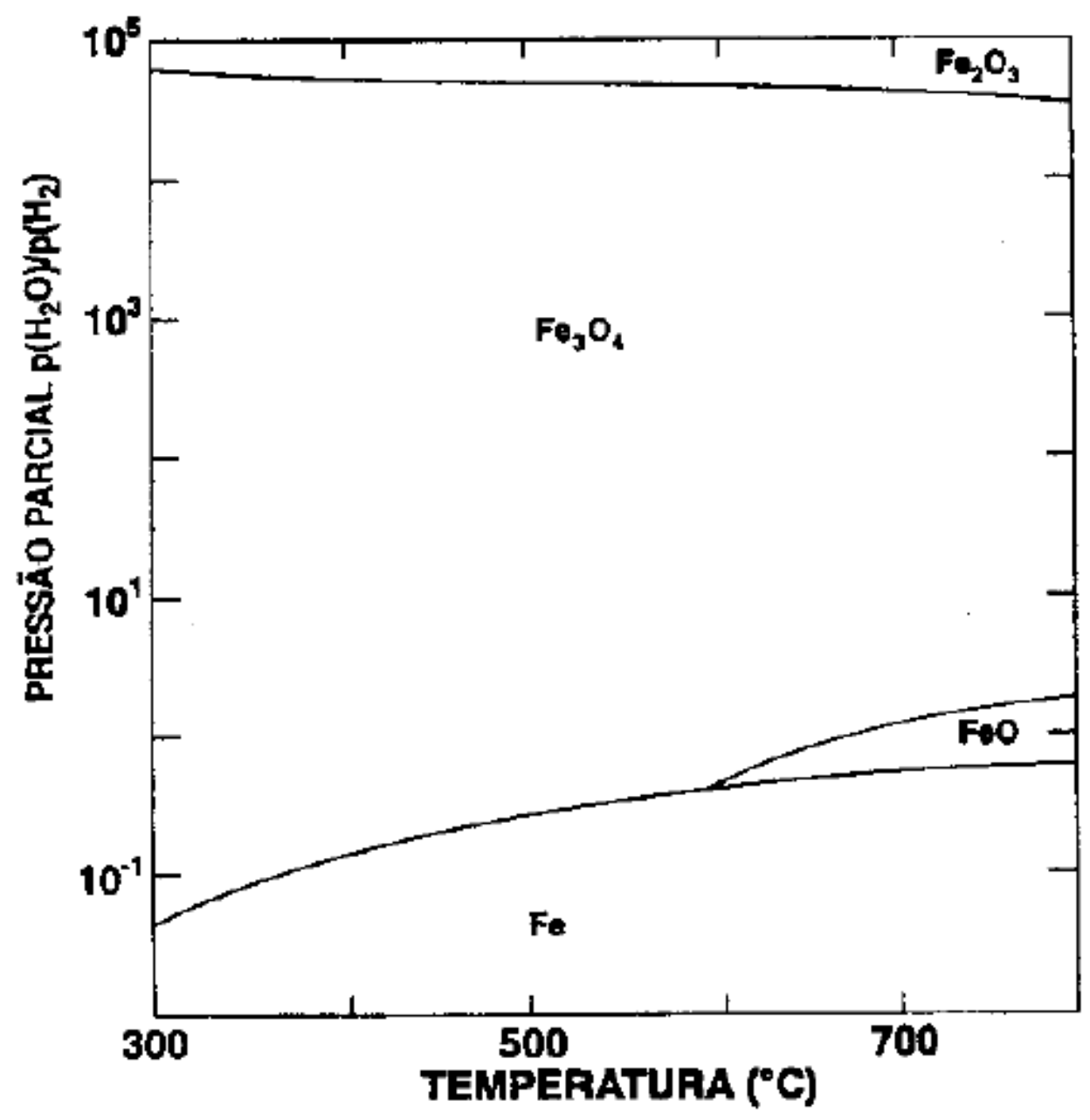

Figura 1 - Diagrama de equilíbrio entre $\mathrm{Fe} / \mathrm{Fe}_{3} \mathrm{O}_{4}$ em função da pressão parcial de $\mathrm{H}_{2} \mathrm{O}$. (BINDER. et al., 1996)

Ferro-oxidação a vapor em forno contínuo industrial - em um forno contínuo industrial as peças sinterizadas são carregadas na esteira do forno.

Elas passam primeiramente pela zona de pré-aquecimento alcançando uma temperatura de $300^{\circ} \mathrm{C}$. Entre a zona de pré-aquecimento e a câmara de tratamento a vapor existe uma região sem aquecimento onde ocorre à exaustão do vapor de água em excesso e o hidrogênio. A temperatura das peças cai até $180^{\circ} \mathrm{C}$ nesta região. 
Logo em seguida as peças entram na câmara de tratamento a vapor. Esta câmara é subdividida em 5 zonas de temperatura.

O vapor entra no meio da zona 5 a uma temperatura de $160^{\circ} \mathrm{C}$, e seu fluxo tem o sentido contrário do fluxo das peças.

É possível alterar a temperatura de cada zona da câmara de tratamento a vapor até um limite, pois, a câmara é continua, sem separações físicas entre as zonas. (EDUARDO NUNES, 2005).

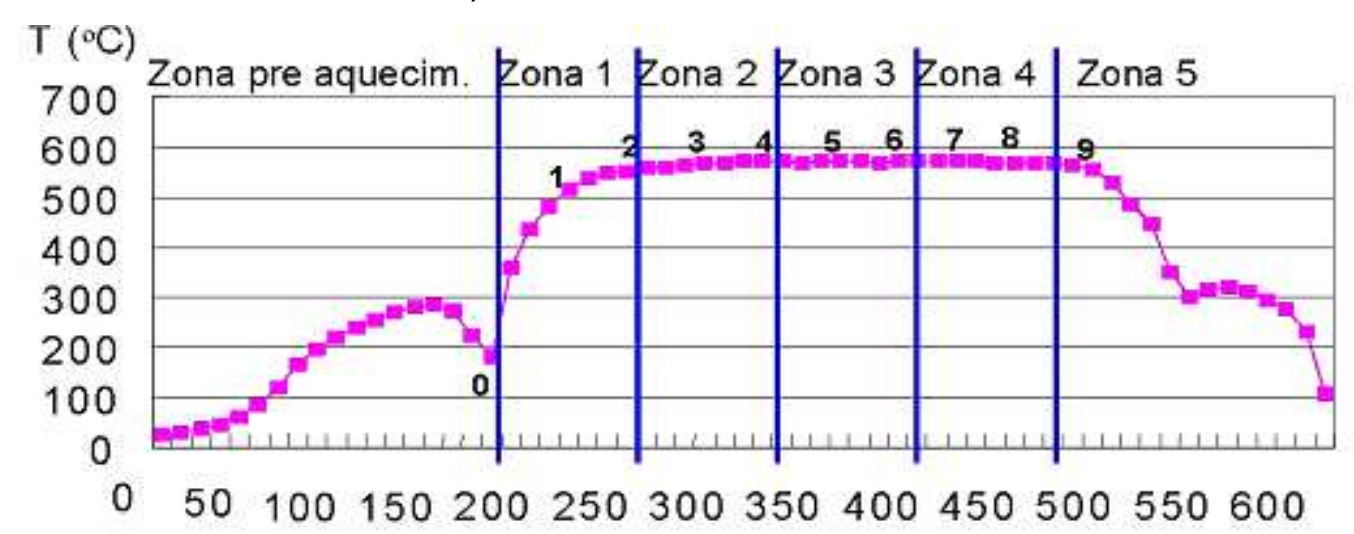

\section{Tempo $(\mathrm{min})$}

Figura 2 - Perfil de temperatura de peças ferro-oxidadas a $5700^{\circ} \mathrm{C}$ em um forno contínuo (EDUARDO NUNES, 2005).

A vazão de vapor é uma das variáveis que podem ser controladas no processo e indica a quantidade de vapor que entra no forno $\left(\mathrm{m}^{3} / \mathrm{h}\right)$, porém, segundo (MOLINARI; STRAFFELINI, 1998), a vazão de vapor afeta principalmente a composição e densificação da camada de óxido, que reflete, por sua vez, na resistência ao desgaste.

As outras variáveis que podem ser controladas no processo de ferrooxidação a vapor no forno industrial são: velocidade das peças, perfil de temperatura e carregamento do forno.

Ferro-oxidação a vapor em forno tipo poço-padrão - O ciclo típico de ferro-oxidação pode ser visto na figura 3. Primeiramente a carga do forno deve ser aquecida acima de $100{ }^{\circ} \mathrm{C}$, mas sempre abaixo do p onto crítico de oxidação ao ar e descoloração $\left(427^{\circ} \mathrm{C}\right)$. Normalmente, é usada a temperatura aproximada de $315^{\circ} \mathrm{C}$ para o primeiro estágio, de 15 a 30 minutos, até que todas as peças atinjam esta temperatura, ou, pelo menos até que o centro da carga do forno 
atinja a temperatura mínima de $100{ }^{\circ} \mathrm{C}$, para evitar a condensação do vapor sobre as peças.

O fluxo de vapor é então introduzido na câmara a uma alta taxa (4,5 a 163 $\mathrm{Kg} / \mathrm{h}$, dependendo do tamanho do forno) para expulsar o ar do forno através da válvula de alívio. Uma vez que a expulsão do ar foi completada, o fluxo de vapor é reduzido à metade e a temperatura é aumentada para valores entre 430 e $6000^{\circ} \mathrm{C}$. A carga é então, mantida a esta temperatura de 0,5 a 4 horas, dependendo da quantidade de óxido que se deseja. Após o tempo necessário, a carga é removida do forno ou é resfriada sob vapor até temperaturas abaixo de $427{ }^{\circ} \mathrm{C}$, para depois removê-la e introduzir nova carga.

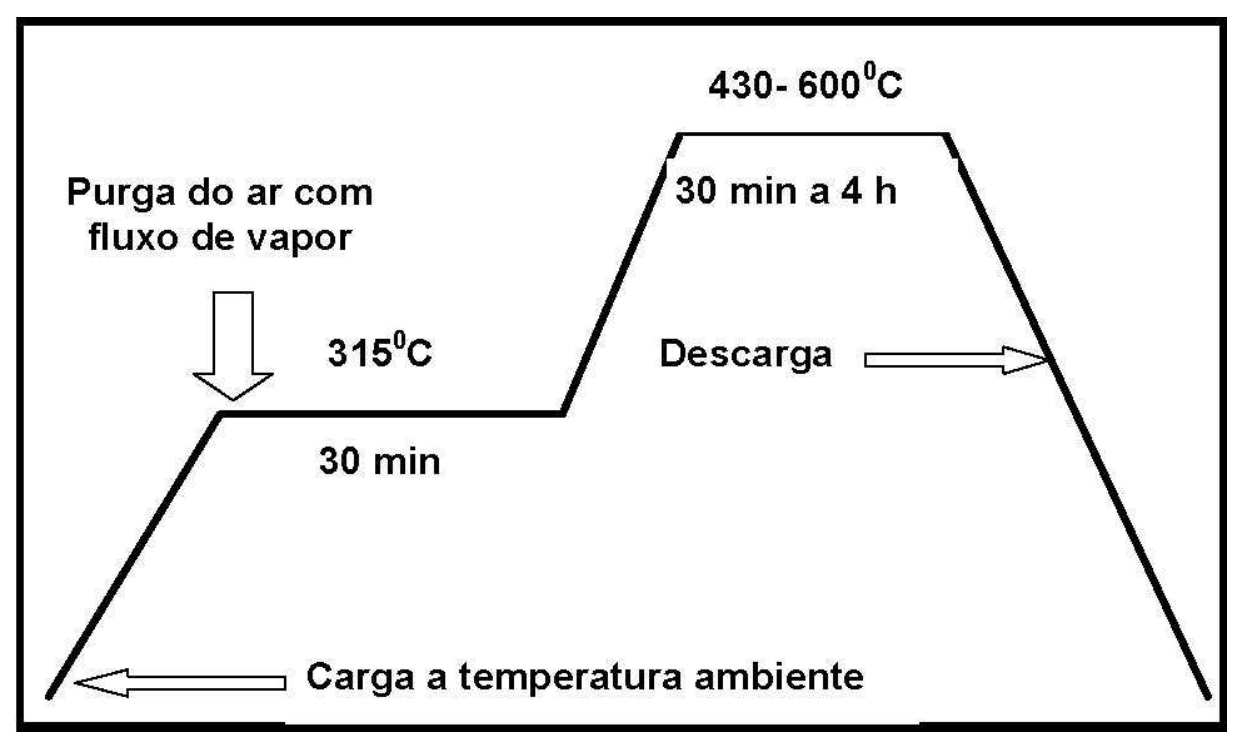

Figura 3 - Ciclo típico da oxidação a vapor de componentes sinterizados (BINDER, et al., 1996).

Com o processamento correto, somente dois tipos de óxidos de ferro se formam: wustita $(\mathrm{FeO})$ e magnetita $\left(\mathrm{Fe}_{3} \mathrm{O}_{4}\right)$.

Valores da temperatura de oxidação inferiores a $430^{\circ} \mathrm{C}$ geram óxidos de coloração azulada, enquanto valores superiores a $620^{\circ} \mathrm{C}$ geram óxidos de coloração cinzenta. (BINDER, et al., 1996).

O processo de oxidação a vapor possui as seguintes variáveis primárias: temperatura, tempo, pressão e composição do vapor.

Uma variável secundária importante para se controlar é a adesão da camada de óxidos superficiais, pois o destacamento ou lascamento da camada superficial de 
óxidos pode ocorrer se a temperatura do processo exceder $570{ }^{\circ} \mathrm{C}$ e o tempo for superior a 4 horas, devido ao aumento das tensões de tração superficiais, como resultado da maior espessura da camada superficial de óxidos.

Para um processo seguro e economicamente favorável, o valor da constante $\mathrm{K}$ deve ser maior ou igual a 1. Durante a reação do Fe com vapor d'água, além do óxido é gerado hidrogênio como um produto secundário (reação 1 ou 5), e até a temperatura de $5700^{\circ} \mathrm{C}$ forma-se $\mathrm{Fe}_{3} \mathrm{O}_{4}$. No entanto, se a pressão parcial de $\mathrm{H}_{2} \mathrm{O}$ for muito alta, pode se formar a hematita $\mathrm{Fe}_{2} \mathrm{O}_{3}$ mesmo em temperaturas abaixo de 570C. (BINDER, et al., 1996).

No processo de oxidação a vapor, alguns cuidados devem ser tomados para se garantir resultados satisfatórios:

1 - As peças e componentes devem estar muito limpos e secos.

Quando as peças são usinadas, calibradas, retificadas ou submetidas às operações de rebarbação após a sinterização, o lubrificante e a água usados nestes processos que ficam retidos nas peças e componentes devem ser totalmente removidos.

Além de dificultar a oxidação das peças, a introdução de lubrificantes (hidrocarbonetos) dentro do forno pode provocar explosões, visto que gases combustíveis são liberados durante o aquecimento do forno, misturando-se com o ar e explodindo quando a temperatura de ignição for atingida.

É muito comum se promover à purga com nitrogênio, para um aquecimento mais seguro, quando esta limpeza não for totalmente garantida.

Também é possível realizar o aquecimento das peças em temperaturas elevadas para eliminar os hidrocarbonetos presentes.

Contudo, se houver água nas peças, ela reagirá com o ferro durante o aquecimento e produzirá hematita como já mostrado; sendo assim este procedimento não é muito indicado.

2 - A purga do ar presente no forno deve ser completa antes de se prosseguir com a elevação da temperatura. Também é importante impedir a entrada de ar no forno quando este estiver acima de $427^{\circ} \mathrm{C}$, uma vez que a sua presença tende a gerar hematita via reações apresentadas nas reações (3) e (4);

3 - Podem ocorrer problemas devido à geração de hidrogênio durante o processo de oxidação a vapor. A reação (1) indica que o hidrogênio é liberado quando o vapor d'água cede oxigênio para formar a magnetita. Se houver admissão 
de ar durante o ciclo de tratamento, pode ocorrer a explosão do hidrogênio presente na atmosfera do forno.

Por isso, em alguns fornos trabalha-se com uma chama piloto que promove a queima contínua do hidrogênio que é liberado.

Portanto, não somente as condições termodinâmicas, como também as condições cinéticas da oxidação a vapor influenciam nas propriedades do material obtido.

(S.A. GALLO; A. VITIELLO; U. PRISCO; HUSSE, 2003) investigaram a influência do tratamento a vapor nas propriedades do aço sinterizado, tendo verificado um grande aumento da dureza, redução de porosidade e uma melhoria nas forças de tração em qualquer direção. Verificou-se também um aumento no módulo de Young, o que foi atribuído à presença da camada de óxido. O aumento relativo da densidade, também aumentou esse módulo.

(D. GRIMANELIS; T.S. EVRE, 2007) usaram o ensaio de desgaste do tipo pino-disco para investigar o comportamento tribológico do aço sinterizado, com e sem tratamento a vapor e com tratamento a vapor e fosfato de manganês, sob várias faixas de velocidade e cargas nas condições de deslizamento a seco e com lubrificação de óleo na estrutura dos poros dos materiais. Verificaram que o aço sinterizado exibiu deformação plástica, que resulta em um deslocamento ao redor do pino bem como um desgaste com a presença de rebarbas. Mecanismo de desgaste por delaminaçào envolve a degeneração dos poros dentro das trincas e este fenômeno foi verificado. A impregnação do óleo no aço sinterizado é benéfica no caso do uso de cargas de até $100 \mathrm{~N}$ e também reduz a rugosidade da pista usada no ensaio pino-disco. O tratamento a vapor quando aplicado com ou sem fosfato de manganês, têm benefícios em termos de aumento de carga no deslizamento a seco e para baixas velocidades de ensaio entre valores de 0,2 a 0,5 m/s.

(ANGELINI, E. et al., 2005) avaliaram a resistência à corrosão por diferentes métodos do aço sinterizado e aço sinterizado com tratamento a vapor, em amostras de pistão usado em compressores para refrigeradores. Foi observado que no caso de amostras com tratamento a vapor, ocorreu um melhoramento na resistência a corrosão em solução de $\mathrm{NaCl}$, enquanto o efeito é modesto em solução de $\mathrm{H}_{2} \mathrm{SO}_{4}$. No teste padrão de névoa salina evidenciou-se um melhor desempenho para as peças que foram tratadas com o processo tratamento a vapor. Verificou-se que em ambiente de solução ácida a resistência à corrosão foi baixa para as peças com 
tratamento a vapor.

(WANG, WEN-FUNG, 2007) investigou dois tipos de pó do fabricante Hoganas esponja e pó atomizado de alta compressibilidade. As amostras foram compactadas com pressão de 300, 400, 500, 600 e 700 MPa antes da sinterização; nas amostras foram feitos tratamentos a vapor a $570^{\circ} \mathrm{C}$ durante $30 \mathrm{~min}$. Conclui-se neste experimento que: 1) A densidade e a dureza do sinterizado aumentam quanto maior a pressão de compactação do pó e estão significativamente influenciadas pelas características estruturais do pó. 2) Durante o tratamento a vapor o tipo de pó e a pressão de compactação exercem influência importante na extensão do fechamento dos poros e ganho de peso. 3) A máxima dureza foi obtida para os componentes compactados com a pressão de $500 \mathrm{MPa}$ para ambos os grupos de pó. 4). As superfícies de poros fechados e resistência à oxidação dos componentes submetidos ao tratamento a vapor são melhorados com aumento da pressão de compactação.

(RAZAVIZADEH; DAVIES, 1979) - testaram dois tipos de pó de ferro da Hoganas (esponja e atomizado) que foram compactados com densidades de 6,0;6,4 e $6,8 \mathrm{Mg} \mathrm{m}^{-3}$, sinterizados e submetidos a ferroxidaçào a vapor a 450, 525, e $600{ }^{\circ} \mathrm{C}$. O progresso de ferro-oxidação foi avaliado pelas medições de ganho de massa e de dureza. Ensaios de Raios-X foram usados para determinar o tipo de óxido presente depois do tratamento a vapor. Durante a ferroxidação o tipo de pó exerceu uma importante influência na extensão de fechamento dos poros e na morfologia do óxido. A cinética da ferro-oxidação foi sempre rápida para o ferro esponja e lenta para o ferro atomizado.

(DE MELLO; R. BINDER; A. N. KLEIN; HUTCHING, 2001) estudaram o efeito da pressão da compactação e classe do pó na microestrutura e também a dureza do ferro sinterizado ferro-oxidado a vapor e detectaram a formação de uma fina camada de óxido constituído de hematita $\left(\mathrm{Fe}_{2} \mathrm{O}_{3}\right)$ e magnetita $\left(\mathrm{Fe}_{3} \mathrm{O}_{4}\right)$ na superfície das amostras bem como na rede de poros. Normalmente esta espessura do óxido foi de $(3,5-4,0 \mu \mathrm{m})$ independente da condição do processo. A camada do óxido produziu endurecimento superficial considerável. A quantidade de óxido formado dentro da porosidade interconectada diminui com a pressão de compactação e aumenta o tamanho do grão do pó e a quantidade do óxido foi fortemente dependente da porosidade 
(DA SILVA; R. BINDER; DE MELLO, 2004) analisaram o desgaste microabrasivo de um aço sinterizado e com tratamento a vapor. Foram usados 16 tipos de pós de aço atomizado com diferentes tamanhos de grãos e pressões de compactação. Os testes microabrasivos foram conduzidos com carga e velocidade constantes, sendo usados três tipos de abrasivos. Verificou-se que a resistência à abrasão é fortemente influenciada pelos parâmetros de processo e que o menor coeficiente de desgaste foi obtido nas amostras em que se utilizou uma pressão alta de compactação com baixo tamanho de grão do pó.

(RAZAVIZADEH; DAVIES, 1981) estudaram o efeito da oxidação a vapor do ferro puro e de ligas $\mathrm{Fe}-\mathrm{Cu}$ na resistência ao desgaste abrasivo, usando para isto uma máquina de desgaste do tipo alternado, em que o contra-corpo era um cone de diamante que agia como elemento abrasivo. As características do equipamento e procedimento utilizado nos ensaios foram: eixo com ponta de diamante de raio $0,2 \mathrm{~mm}$ que foi inclinado a 120 graus; comprimento do curso de $1 \mathrm{~cm}$; velocidade de $0,5 \mathrm{~cm} / \mathrm{s}$; distância de deslizamento de $1000 \mathrm{~cm}$ e testadas com cargas de 1, 3, 5, 7 e $9 \mathrm{Kgf}$. Foram testadas amostras de ferro puro e ligas $\mathrm{Fe}-\mathrm{Cu}$ com várias porcentagens de cobre $(2,4,6$ e $8 \%)$ em duas condições: como sinterizado e oxidado a vapor. $\mathrm{O}$ volume do desgaste foi medido com a distância de deslizamento de $1000 \mathrm{~cm}$.

$\mathrm{Na}$ Figura 4 é apresentado o equipamento de desgaste utilizado nos ensaios e na figura 5 os resultados dos ensaios.

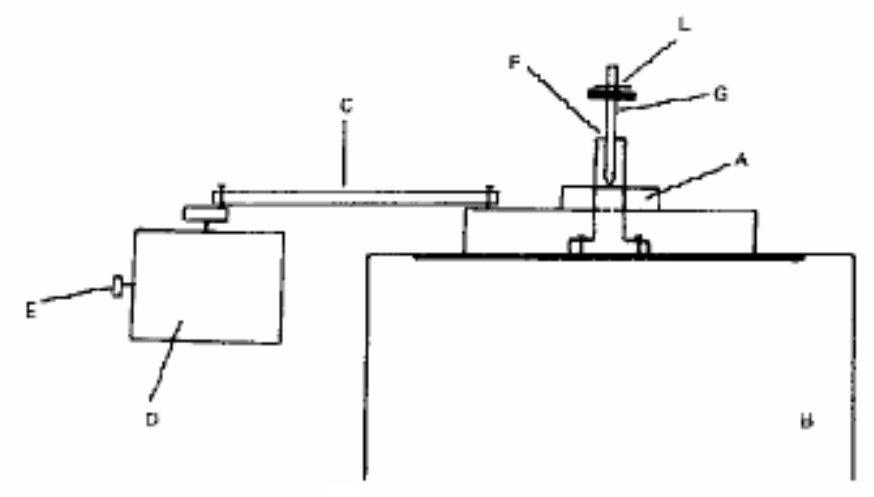

Figura 4 - Equipamento de desgaste: A - amostra; B - Máquina de desgaste; C - Braço; D - Motor Elétrico; E - Botão para controle da velocidade; F - Suporte; G - Eixo; L - Carga. 


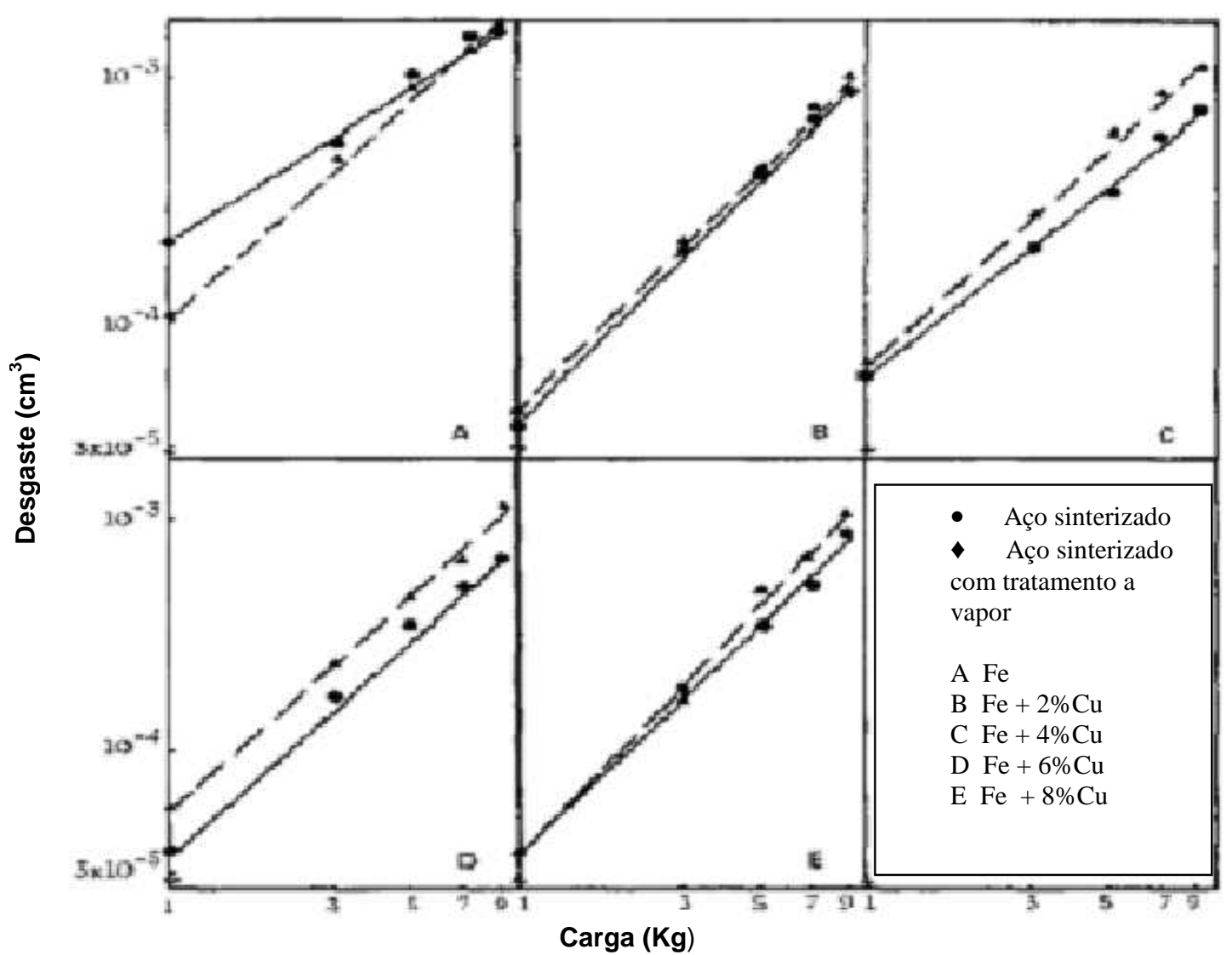

Figura 5 - Volume de desgaste em função da carga depois de deslizamento de $1000 \mathrm{~cm}$.

O volume de desgaste das amostras (Fe puro) sinterizadas é maior do que nas amostras sinterizadas com oxidação a vapor, até a carga de 7 Kgf. Sob cargas maiores a situação é reversa (figura 5 linha $A$ ).

A oxidação a vapor diminui a resistência ao desgaste abrasivo nas ligas sinterizadas Fe-Cu com adição de cobre de 2, 4 e 6\% (figura 5 linhas B, C, D).

O desgaste do aço sinterizado foi melhorado pelo tratamento a vapor pela adição de cobre (8\%) na liga Fe-Cu (figura 5 linha E).

(STRAFFELINI; MOLINARI, 1992) estudaram o procedimento do deslizamento em função da velocidade a seco do ferro sinterizado e com tratamento a vapor com amostras de $\mathrm{Fe}-2 \% \mathrm{Cu}$ e $\mathrm{Fe}-3 \% \mathrm{Cu}$. Os resultados de testes de desgaste indicaram que os coeficientes de desgaste são baixos e independente da composição química das amostras, desde que a camada de óxido, produzida pela ferro- oxidação a vapor, atue como lubrificante entre as superfícies em deslizamento. Depois de removida a camada de óxido a resistência ao desgaste por deslizamento diminui. Depois de removida a camada de óxido pelo desgaste adesivo, dois mecanismos de desgaste são ativos: a delaminação a baixa velocidade de 
deslizamento e a delaminação-oxidação a alta velocidade de deslizamento. Quando a delaminação é mecanismo predominante, cobre e carbono são muitos efetivos e melhoraram a resistência ao desgaste formando assim uma grande influencia. $O$ óxido formado nas porosidades interconectadas durante a ferroxidação a vapor contribui para a resistência ao desgaste, embora as propriedades mecânicas diferentes da $\mathrm{Fe}_{3} \mathrm{O}_{4}$ e do ferro poderiam produzir um campo de tensão na microestrutura que favorece a nucleação e propagação de trincas.

(STRAFFELINI; MOLINARI, 1995) estudaram o deslizamento a seco em 3 tipos de amostras de ligas sinterizadas e oxidado a vapor: $\mathrm{Fe}, \mathrm{Fe}-2 \% \mathrm{Cu}, \mathrm{Fe}-0,3 \% \mathrm{C}$ com o objetivo de esclarecer a durabilidade da superfície da camada de óxido influenciada pelas características de microestruturas bem como as cargas aplicadas. Verificou-se que sob cargas altas 60-100N o desgaste é metal-metal e severo, porque a remoção inicia de imediato na camada de óxido. A durabilidade das superfícies nos ensaios demonstrou que a resistência ao desgaste que obteve melhor resultado foi à amostra do $\mathrm{Fe}-0,3 \% \mathrm{C}$, seguido pela amostra de Ferro puro e por último a amostra do $\mathrm{Fe}-2 \% \mathrm{Cu}$. Concluiu-se que esta seqüência está ligada às características de microestrutura mais favoráveis para os materiais base, o que melhora a estrutura da camada de óxido formada durante o tratamento a vapor.

(DE MELLO; HUTCHINGS, 2001) estudaram o desgaste por deslizamento em amostras de ferro sinterizado e oxidado. Verificou-se que durante o desgaste a fragmentação de partículas de óxidos, assim como a deformação de partículas metálicas originadas da amostra e do contra corpo que produz uma degradação gradual e localizada da camada que é o principal fator que controla o processo de desgaste. Estes autores mostraram claramente, que nos estágios finais de remoção da camada de óxido as partículas duras, originadas da fragmentação da camada, causam desgaste do tipo abrasivo, sendo este mecanismo o principal agente de degradação do sistema.

(GLADKOVA; GUSEV; SOVETOVA, 1970) investigaram o efeito das condições de resfriamento após tratamento de ferro-oxidação a vapor na estrutura da camada de óxido. Quando a peça é resfriada ao ar a partir de temperaturas entre 450 e $550^{\circ} \mathrm{C}$ a magnetita $\mathrm{Fe}_{3} \mathrm{O}_{4}$ é oxidada formando uma fina camada de hematita $\mathrm{Fe}_{2} \mathrm{O}_{3}$ na superfície externa. Caso a peça seja resfriada até $250^{\circ} \mathrm{C}$ dentro do forno sob atmosfera de vapor d'água a magnetita não é oxidada, no entanto, $\mathrm{Fe}_{2} \mathrm{O}_{3}$ pode se formar no caso de o tempo de exposição ao ar em temperaturas da ordem de 
$250^{\circ} \mathrm{C}$ sejam longos o suficiente para ocorrer à oxid ação. À medida que a camada de óxido ganha espessura, a dificuldade de penetração de vapor nos poros internos aumenta, de maneira que, quanto mais afastados da superfície, maior a dificuldade de penetração do vapor e conseqüente saída do hidrogênio.

(GRAHAM; HUSSEY, 1987) descreveram um mecanismo de formação de poros durante oxidação do ferro devido à precipitação de lacunas de cátions que chegam à interface metal / óxido, e isto, pode causar uma separação do óxido do metal impedindo transporte de cátions de ferro, causando assim, uma desaceleração da reação. Após o tratamento a vapor a dureza aumenta, pois, a dureza do óxido formado (magnetita) é aproximadamente 10 vezes maior que a do ferro (50 HV).

(P. BEISS, 1991) estudou o efeito da densidade sobre o ganho de massa e a profundidade de penetração do óxido. As figuras 6 e 7 indicam a dependência das espessuras da camada de óxido do $\mathrm{Fe}-0,5 \% \mathrm{C}$ no tempo e temperatura. A utilidade do tratamento a vapor para uma aplicação deve ser decidida a partir do equilíbrio entre ductilidade e dureza.

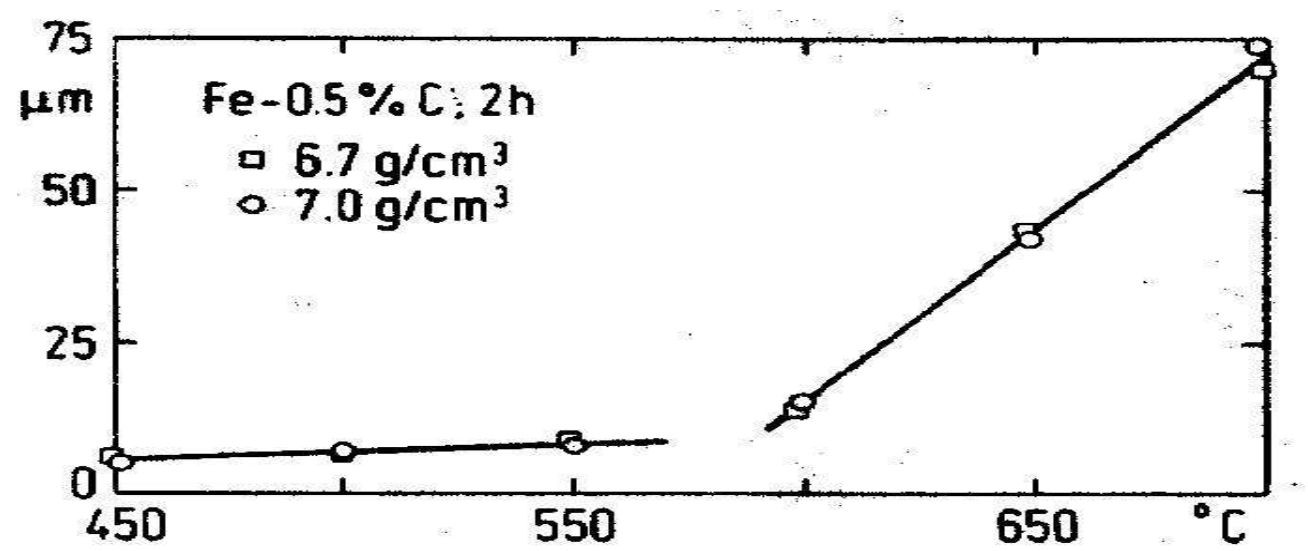

Figura 6 - Espessura $(\mu \mathrm{m})$ da camada em função da temperatura $\left({ }^{\circ} \mathrm{C}\right)$ para dois níveis de densidade (EDUARDO NUNES, 2005).

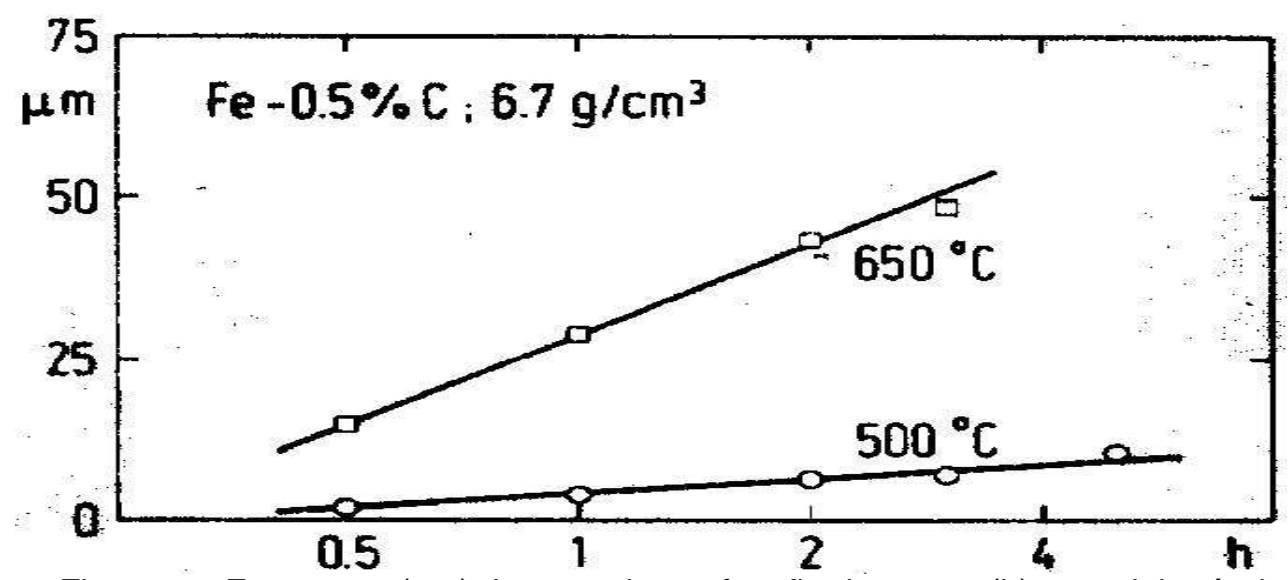

Figura 7 - Espessura $(\mu \mathrm{m})$ da camada em função do tempo $(\mathrm{h})$ para dois níveis de temperatura (EDUARDO NUNES, 2005). 
(ZUM GAHR, 1987; STRAFFELINI; MOLINARI, 2001) - Verificou-se que avaliações e comparações sob diferentes condições de ensaios de desgaste, em termos de parâmetros tribológicos e configurações geométricas, são difíceis de serem realizados. Para minimizar estas limitações, (STRAFFELINI; MOLINARI, 2001) propuseram o uso dos conhecidos mapas de desgaste dos aços propostos por (LIM; ASHBY, 1987), para se mapear as regiões das condições operacionais destes ensaios e desta forma se obter uma visão unificada de todos os resultados experimentais e fazer comparações confiáveis. Os mapas de desgaste dos aços, propostos por (LIM; ASHBY, 1987), apresentam de um modo gráfico os domínios ou territórios associados aos diferentes mecanismos de desgaste predominantes e também informações sobre taxas de desgaste e os seus contornos em função dos principais parâmetros tribológicos controladores destes mecanismos, que são a pressão normal aplicada e a velocidade de deslizamento. Os ensaios dos principais trabalhos existentes na literatura sobre os materiais ferrosos sinterizados e as regiões das condições tribológicas referentes e estes ensaios, apresentadas por vários pesquisadores também foram inseridas no mapa de desgaste da figura 8 por (ANTONIO BOZZI, 2004).

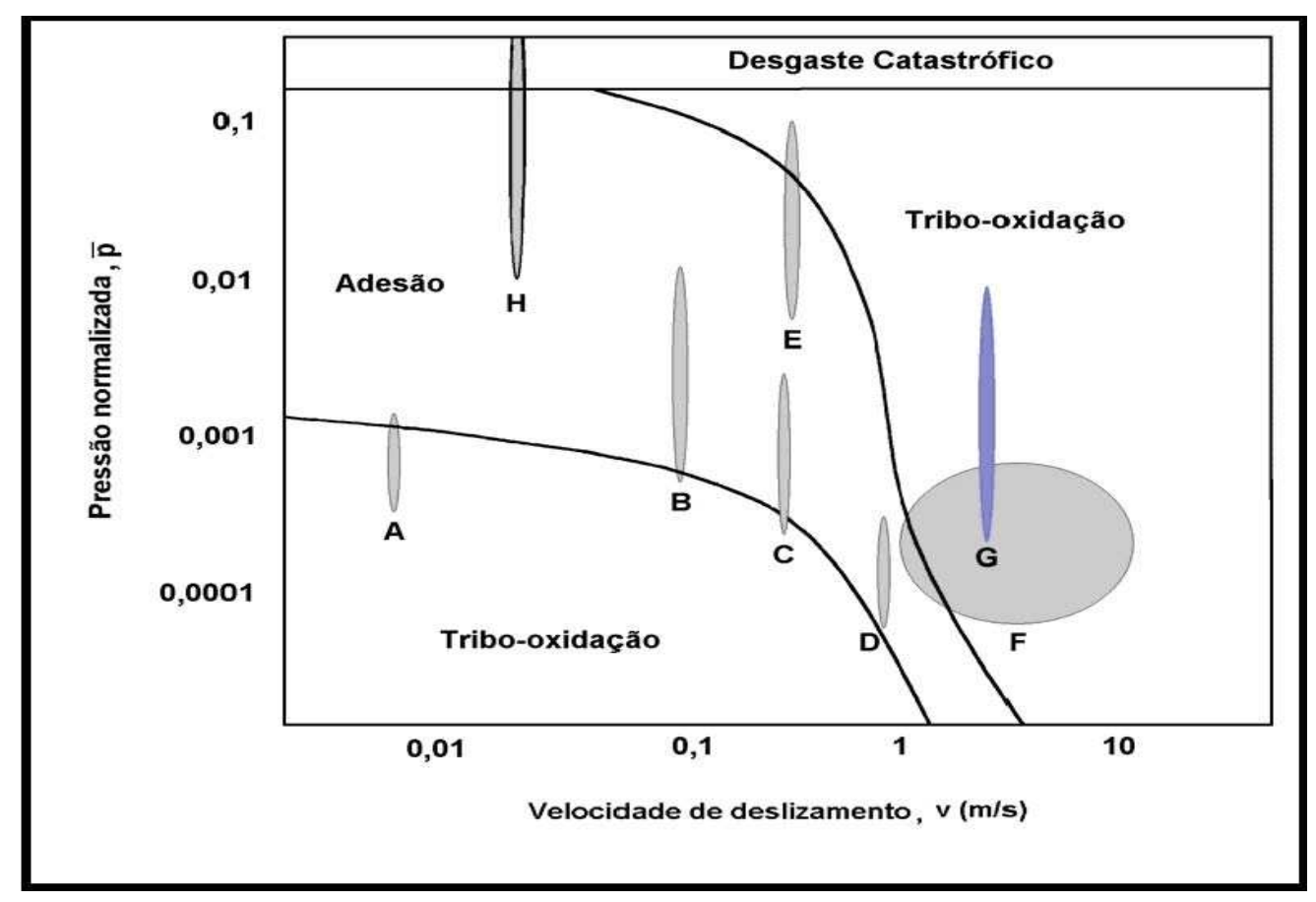

Figura 8 - Mapa de desgaste esquemático dos aços mostrando as janelas ou regiões das condições tribológicas dos principais trabalhos com ligas ferrosas sinterizadas da literatura e os domínios dos mecanismos de desgaste predominantes em função da velocidade de deslizamento e da pressão normalizada. A - LEHEUP et al. (1998); B - MOLINARI; STRAFFELINI (1994), MOLINARI et al. (1999); C - LIM; BRUNTON (1986); D - TASKINEN; TIKKANEN (1984); E - AMSALLEM et al. (1971); F - WANG; DANNINGER (1998); G - EYRE; WALKER (1976); H - incluído no trabalho apresentado por ANTONIO BOZZI (2004). 
Os ensaios tribológicos realizados por (ANTONIO BOZZI, 2004) foram mais agressivos do que os demais, com alta severidade nos instantes iniciais chegando a levar as suas condições tribológicas à predominância do regime de desgaste catastrófico, como se observa na parte superior da região $\mathrm{H}$. Estas condições não devem prevalecer e, com o desgaste da esfera, a pressão de contato cai rapidamente, e o regime de desgaste por adesão predomina durante a maior parte dos ensaios. Neste regime, o desgaste é o resultado da deformação plástica dos contatos metálicos entre as asperidades dos materiais e é, em geral, severo, ao contrário daquele por tribo-oxidação que é suave por causa da ação protetora exercidas pelos filmes de óxidos. De acordo com o mapa de desgaste, em todos os ensaios realizados nas amostras sinterizadas sem oxidação a vapor predominou o desgaste por meio do processo adesivo. Outros mecanismos podem operar simultaneamente em menores intensidades. Neste caso o mecanismo conhecido como tribo-oxidação a baixas velocidades de deslizamento podem operar e neste mecanismo os fragmentos metálicos de desgaste são inicialmente formados pela adesão e permanecem alojados na região de contato e poros superficiais. Apesar das baixas temperaturas de contato eles se oxidam devido à alta reatividade de suas superfícies, podendo se aglomerar e também se fragmentar, gerando detritos de óxidos que causam a abrasão.

(SULLIVAN; HODGSON, 1988; HUTCHINGS, 1992) - Nos aços carbono e de baixa liga, as fases óxidas presentes nos detritos de desgaste dependem da temperatura de contato. A hematita é predominante até uma temperatura de $200{ }^{\circ} \mathrm{C}$, a magnetita em temperaturas entre $200^{\circ} \mathrm{C}$ e $570^{\circ} \mathrm{C}$ e a wustita acima de $570^{\circ} \mathrm{C}$. Como esta temperatura do contato depende primordialmente da velocidade de deslizamento, a baixas velocidades de deslizamento predomina a hematita com a wustita e a magnetita predomina em velocidades intermediárias.

(STRAFFELINI; MOLINARI, 2001) - nos mecanismos de desgaste atuantes dos vários trabalhos de outros autores, obtidas por este mapa de desgaste, apresentaram uma boa concordância com os mecanismos reais observados. Assim, o uso do mapa de desgaste se mostrou mais uma ferramenta adicional importante para ajudar na interpretação do comportamento em desgaste das amostras sinterizadas sem oxidação dos presentes ensaios e, principalmente, permitiu uma comparação relativa de suas condições de severidade com as de outros ensaios. Contudo, deve ficar bastante claro, que este mapa de desgaste deve ser 
considerado somente como uma primeira aproximação, que fornece uma visão unificada e comparativa dos vários trabalhos sobre os materiais ferrosos sinterizados às custas de um melhor nível de detalhes e precisão sobre os mecanismos específicos e taxas de desgaste atuando em cada caso, pois segundo (LIM; ASHBY, 1987), "um mapa de desgaste é um resumo da compreensão atual e imperfeita da tribologia, não uma declaração exata".

(ANTONIO BOZZI, 2004) - o mapa de desgaste da figura 8 foi construído e utilizado apenas para se estudar o comportamento em desgaste das amostras sinterizadas sem oxidação, não podendo ser utilizado para se analisar o comportamento de desgaste das amostras sinterizadas e oxidadas a vapor. O mapa de desgaste pode ser usado de maneira didática para mostrar o efeito da oxidação a vapor no comportamento tribológico. A oxidação a vapor pode ser entendida como uma forma de se deslocar às condições tribológicas operacionais de um domínio de desgaste por processos mecânicos ou adesão para um domínio de desgaste por tribo-oxidação com o objetivo de se obter o desgaste suave, uma vez que ele pode ser alcançado através da formação de camadas protetoras de óxidos. A camada superficial de óxidos formada pela oxidação a vapor não é auto-regenerativa, e uma vez destruída desloca as condições tribológicas operacionais de volta ao domínio dos processos adesivos.

Segundo vários pesquisadores, dentre eles RUTHERFORD; HUTCHINGS, (1996) e GEE M.G. et al., (2003) os ensaios de microdesgaste são muito usados e importantes para que a indústria disponha de um ensaio adequado à simulação dos comportamentos de desgaste de diferentes tipos de materiais e camadas, para facilitar uma escolha econômica e confiável para cada tipo de aplicação. Deve-se ressaltar ainda que o valor do desgaste não está relacionado apenas ao material empregado, mas depende da combinação de todos os materiais presentes e dos fatores envolvidos no processo de desgaste como um todo.

$\mathrm{O}$ ensaio de microdesgaste consiste em promover o contato entre uma esfera e uma amostra plana, com ou sem a presença de abrasivo, com a esfera girando em relação à amostra. $O$ resultado desse contato é uma região desgastada em forma de calota esférica, que mantém relações geométricas com a esfera que a gerou. Assim ao se medir o diâmetro da calota pode-se relacioná-lo com a quantidade de material removida. 
A figura 9 ilustra a geometria da calota formada pelo ensaio de microdesgaste.

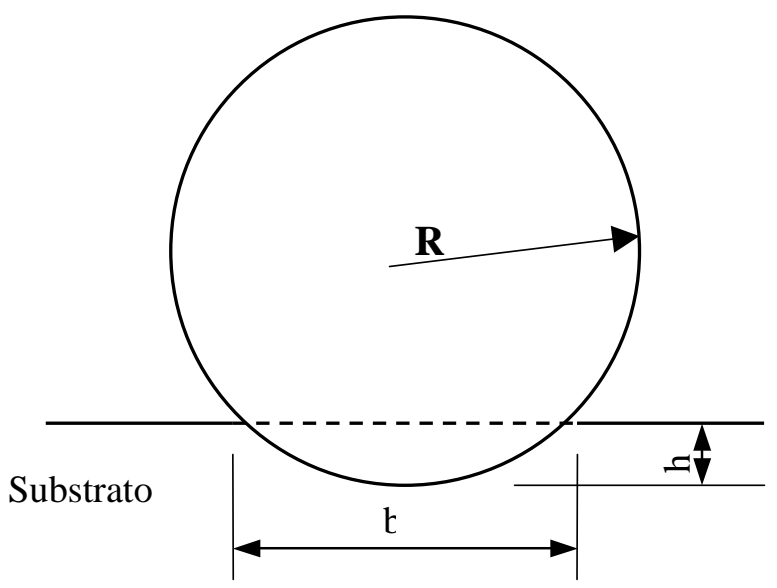

Figura 9 - Diagrama esquemático que ilustra a geometria da calota formada pelo ensaio de microdesgaste.

Para uma calota de desgaste com geometria esférica produzida por uma esfera de raio "R" numa amostra plana, o volume desgastado pode ser calculado de acordo com a seguinte relação:

$$
V=\pi \frac{b^{4}}{64 R^{2}}\left(R-\frac{b^{2}}{8 R}\right) \approx \frac{\pi b^{4}}{64 R} \quad \text { para } \mathrm{b}<<<\mathrm{R}
$$

Onde:

$\mathrm{R}$ - é o raio da esfera;

b - é a diâmetro médio da calota;

V - é o volume de desgaste; 
A configuração com esfera presa ilustrada na Figura 10a é utilizada para promover cargas elevadas e conseqüentemente altas tensões no ensaio. A configuração com a esfera livre ilustrada na Figura 10b promove pequenas cargas no ensaio. Por possibilitar uma variedade abrangente de ajuste, o ensaio tipo calo teste tem sido amplamente utilizado em diferentes materiais.

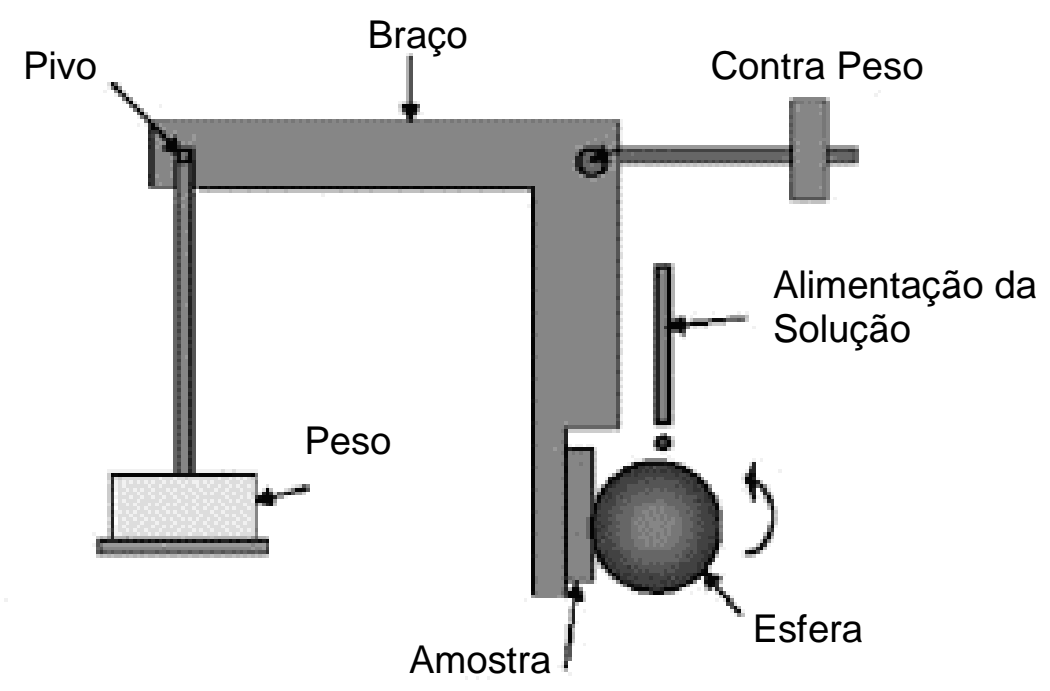

\section{a) Configuração Esfera Presa}

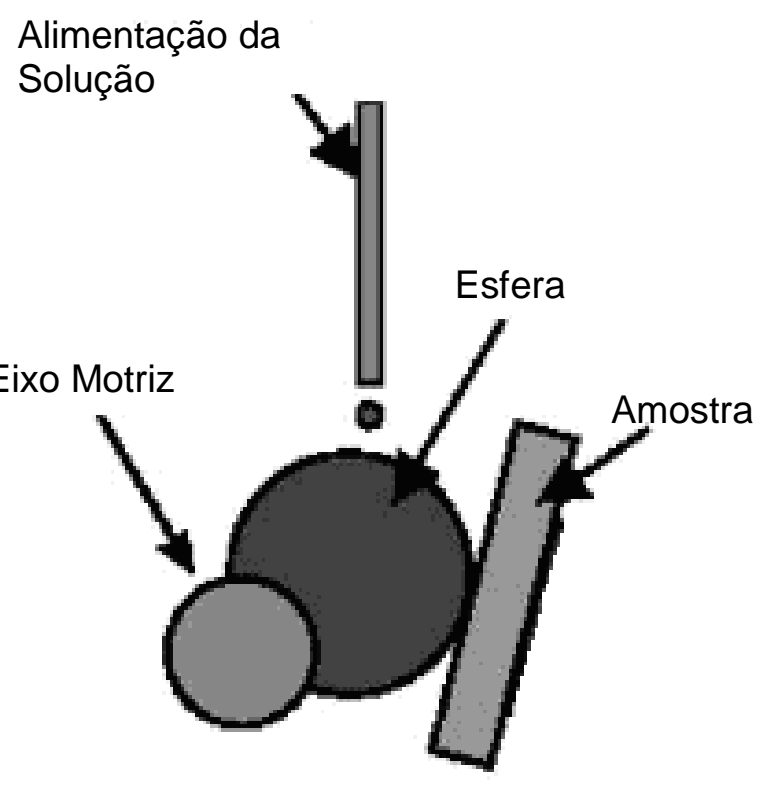

b) Configuração Esfera Livre

Figura 10 - Diagramas esquemático de funcionamento do ensaio de microdesgaste com esfera livre e presa 


\section{CAPÍTULO 3}

\section{PROCEDIMENTOS EXPERIMENTAIS}

Apresenta-se na figura 11 o fluxograma do processo dos procedimentos realizados no presente trabalho:

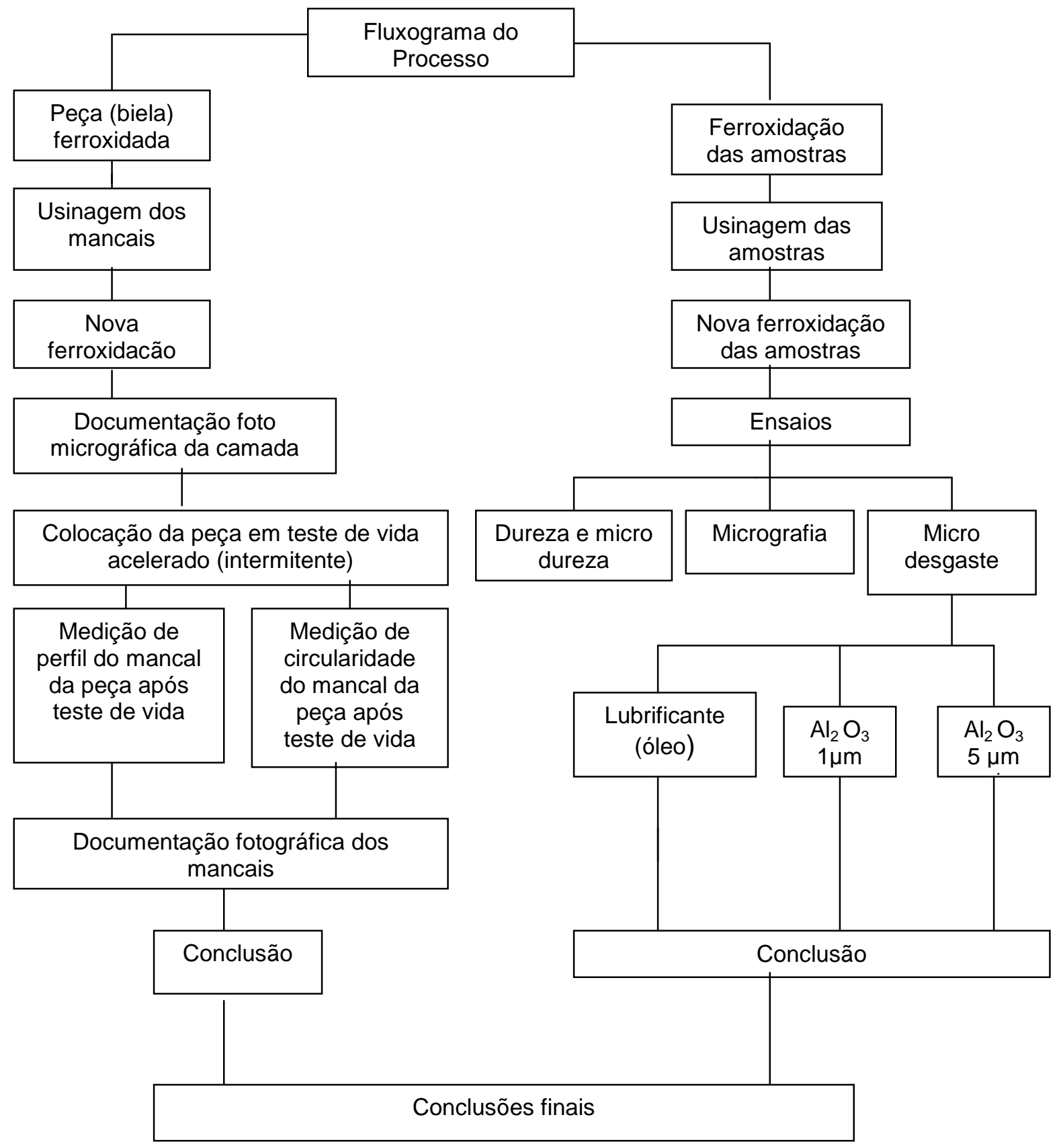

Figura 11 - Fluxograma do processo dos procedimentos experimentais 
O ferro sinterizado do componente (biela) e amostras estudadas neste experimento apresentam a seguinte característica:

- Pó de aço atomizado AHS10 -29 - Hoganas

- $\quad$ Densidade $=6,80 \mathrm{~g} / \mathrm{cm}^{3}$ (amostras testadas e biela)

As seqüências de processo para obtenção do componente são:

- $\quad$ Compactação do pó.

- Sinterização em um forno contínuo sob atmosfera constituída de $95 \% \mathrm{~N}_{2}$ e $5 \% \mathrm{H}_{2}$ - temperatura de $1120{ }^{\circ} \mathrm{C}$.

- Ferro-oxidação a vapor em forno contínuo a uma temperatura de $570^{\circ} \mathrm{C}$ (tempo total do ciclo $=8$ horas)

- Usinagem dos mancais.

- Ferro-oxidação a vapor em forno contínuo a uma temperatura de $570{ }^{\circ} \mathrm{C}$ (tempo total do ciclo $=8$ horas) visando obte $r$ a camada de óxido nos mancais do componente.

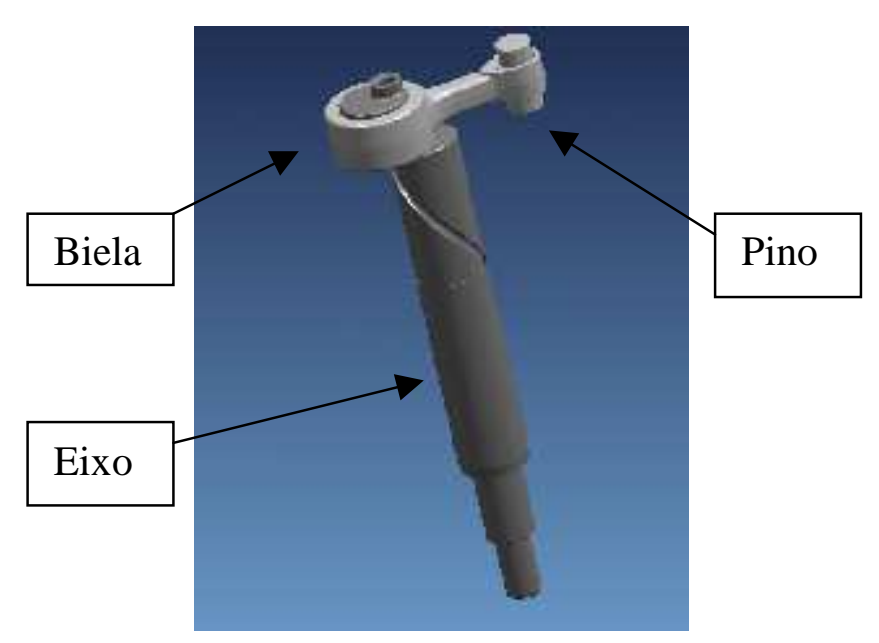

Figura 12 - llustração de um componente similar aplicado em um compressor hermético e seus respectivos mancais.

Fonte: Tecumseh do Brasil Ltda

O componente (biela) é aplicado em um compressor hermético alternativo para refrigeração doméstica, que é um elemento fundamental na indústria de refrigeração. Esse compressor alternativo consiste de um pistão que se move alternadamente no interior de um cilindro.

Como o compressor hermético usa um sistema de movimentação mecânica para desempenhar a função de compressão, suas partes móveis estão sujeitas ao atrito e conseqüentemente ao desgaste se não forem tribologicamente bem 
dimensionadas.

O eixo dos mancais possui superfícies altamente solicitadas por atrito e cargas variáveis, podendo sofrer danos se a solicitação específica for alta demais e pode conduzir a falha da peça.

O contato metal-metal dos mancais é inevitável neste tipo de equipamento durante partidas e paradas, o que exige que as superfícies sejam produzidas de forma adequada tal que a solicitação especificada se torne a menor possível.

As propriedades exigidas neste tipo de mancal estão diretamente relacionadas com a especificação do material, propriedades térmicas e químicas, resistências estruturais, processo de fabricação, acabamento superficial, dentre outras (ENIO FREITAS, 2006).

As seqüências dos procedimentos experimentais (ensaios) do presente trabalho foram os seguintes:

1 - Normalmente para se obter a camada ferroxidada pelo processo de tratamento a vapor é exigido que não haja óleo presente nas peças, oriundo de processos anteriores como usinagem, uma vez que esse lubrificante pode prejudicar a qualidade do tratamento bem como pode provocar explosões dentro do forno. Para isso, normalmente é realizada a queima do óleo a temperaturas próximas a $760^{\circ} \mathrm{C}$. Porém nestas temperaturas podem ocorrer distorções dos diâmetros dos mancais da biela. Como a peça (biela) antes da operação de usinagem foi ferroxidada foi considerado que pelo fechamento acentuado da porosidade, a presença de óleo existente nas peças seria minimizada. Para a verificação do comportamento do óleo em função da temperatura, foram realizados testes de comportamentos térmicos de termogravimetria . A termogravimetria é definida como uma técnica termoanalítica na qual a massa de uma substância é medida em função da temperatura. Uma pequena quantidade de amostra é colocada em um cadinho de alumina, onde a massa é constantemente monitorada por uma termobalança.

Para fins de comparação, além do óleo usado no processo de usinagem da biela ora estudada, foi testado também um outro óleo utilizado por outros fabricantes em processos de calibração de mancais.

2 - Tipos de acabamentos superficiais, do componente biela, utilizados nestes ensaios estão descritos nos itens $A$ e B:

A) A biela obtida pelo processo de sinterização foi submetida ao processo de ferro-oxidação a vapor. A seguir os mancais (diâmetros) da biela foram usinados 
para se obter a dimensão final. Conseqüentemente, com a operação de usinagem a camada ferroxidada existente foi eliminada dos mancais.

B) Para se refazer a camada ferroxidada dos mancais da biela, a mesma foi submetida novamente ao processo de ferro-oxidação a vapor.

Foram realizados testes comparativos de desgaste do componente (biela) que foi montado e testado em um compressor hermético e submetido à teste de funcionamento intermitente (parada e partida) durante 170 dias.

3- Ensaios de microdesgaste com esfera presa e solta foram realizados para comparar resultados do volume desgastado entre a amostra sem e com a camada ferroxidada nas seguintes situações:

A) Ensaio de esfera presa: utilizando como lubrificante o mesmo óleo utilizado no compressor (POE viscosidade $10 \mathrm{cSt}$ ) entre a amostra e a esfera.

B) Ensaio de esfera livre: estes ensaios foram feitos em 3 situações distintas entre a amostra e a esfera:

- Lubrificante (óleo) mesmo utilizado no compressor

- Abrasivo (Alumina 1 $\mu \mathrm{m}$ )

- $\quad$ Abrasivo (Alumina $5 \mu \mathrm{m}$ ) 


\section{MATERIAIS E MÉTODOS}

\section{1- Ensaio Metalográfico}

Seccionamento ou corte da biela e amostras de testes: os cortes foram executados numa máquina de corte do tipo CUT-OFF, com refrigeração de óleo solúvel em água, tendo como ferramenta de corte um disco abrasivo em alta rotação. $O$ corte foi realizado transversalmente.

Embutimento da peça biela: a amostra foi embutida em resina baquelite e envolvida em folha de alumínio para preservar a camada de óxido.

Embutimento da amostra de teste: a amostra foi embutida em resina baquelite especial para evitar arredondamento das arestas e preservar a camada de óxido.

Lixamento da peça biela: foi lixada em lixadeira elétrica, utilizando lixas com as seguintes granulometrias: 180, 220, 320, 400 e 600 mesh. O lixamento em cada lixa foi efetuado até o ponto em que os riscos produzidos no estágio anterior desaparecessem totalmente.

Lixamento das amostras de testes: foi lixada em lixadeira manual, utilizando lixas com as seguintes granulometrias: 220, 320, 400 e 600 mesh. Em cada um destes estágios de lixamento, o corpo de prova foi movimentado sobre a superfície de tal maneira que os riscos fossem formados apenas numa direção. $O$ lixamento em cada lixa foi efetuado até o ponto em que os riscos produzidos no estágio anterior desaparecessem totalmente.

O procedimento de lixamento das amostras utilizadas nos testes de microdesgaste foi similar ao descritos neste item somente para as amostras sem a camada ferroxidada, paras as amostras de testes com a camada ferroxidada não houve lixamento.

Polimento da peça biela: após lixamento foi polida em óxido de alumínio de granulometria de $3 \mu \mathrm{m}$. 
Polimento da amostra de teste: após lixamento foi polida inicialmente em óxido de cromo de granulometria de $10 \mu \mathrm{m}$ e posteriormente com pasta de diamante na seguinte granulometria: $9,6,3,1 \mu \mathrm{m}$.

Ataque químico da peça biela: foi realizado o reagente Nital 3,5\% e a foto micrografia em Microscópio óptico Olimpus BX60M.

Ataque químico da amostra de teste: foi realizado o reagente Nital 2,0\%, a foto micrografia e medição da camada de óxido foram feitas no Microscópio Zeiss Axiotech.

\section{2- Ensaios de dureza e microdureza}

Para as medições de durezas e microdurezas nas amostras testadas foram utilizados os seguintes equipamentos:

- $\quad$ Dureza - Durômetro Leco - RT240

- Microdureza - Microdurômetro Buehler modelo 1600-6300

\section{3- Medições de perfil e circularidade}

Para as medições de perfis e circularidades realizadas nos mancais da biela foram utilizados os seguintes equipamentos:

- $\quad$ Perfil - Analisador de superfície modelo Form Taly Surf Série 2 (Taylor Hobson).

- $\quad$ Circularidade - Talyround modelo 265 (Taylor Hobson).

\section{4- Medição da camada de óxido realizado na biela}

Para medição da camada de óxido realizado no mancal da biela foi utilizado o seguinte equipamento:

- MEV (Microscopia Eletrônica de Varredura - Equipamento Stereoscan 440 LEO) 


\section{CAPÍTULO 4}

\section{RESULTADOS E DISCUSSÃO}

As micrografias óticas das camadas ferroxidadas produzidas em material da biela de compressor e amostras de testes estão mostradas nas Figuras 13 e 14 .

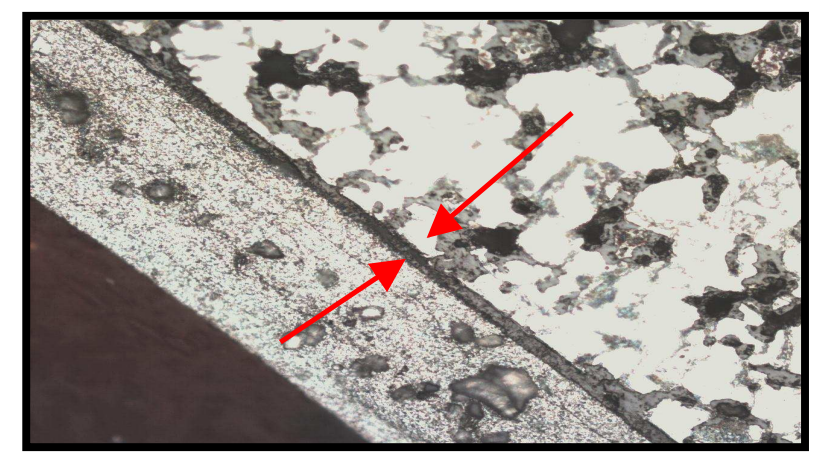

Figura 13 - Camada ferroxidada produzida na biela. Ampliação: 150X.

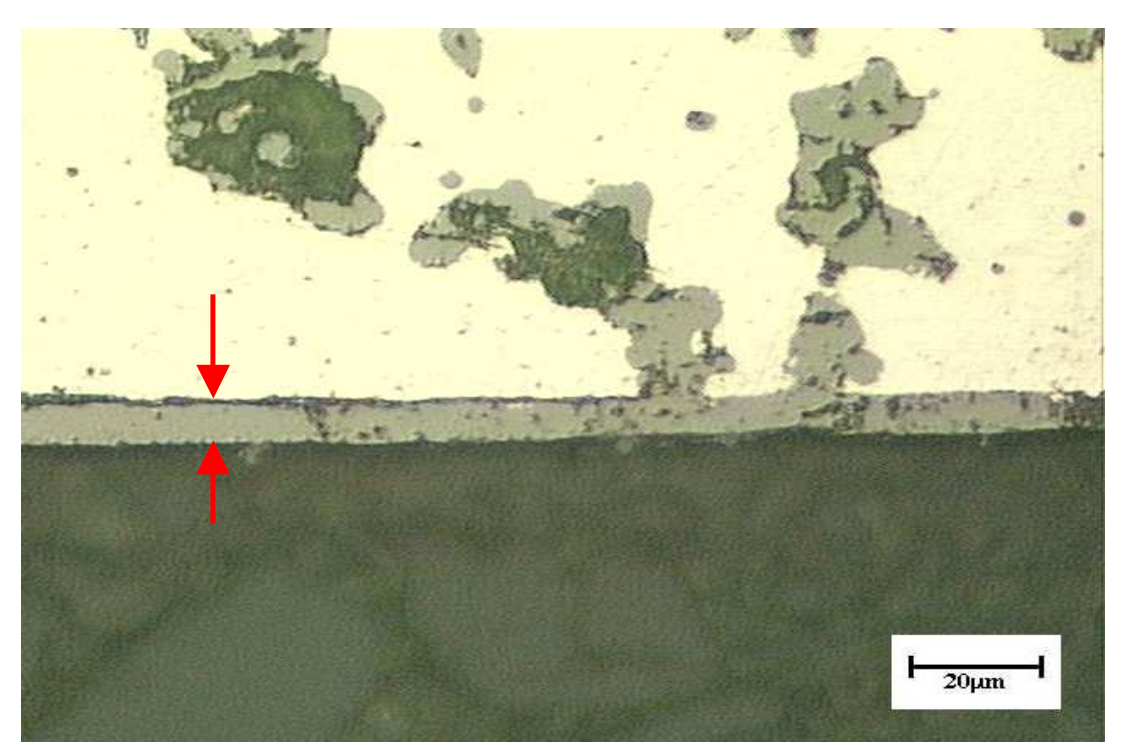

Figura 14 - Camada ferroxidada produzida em amostra de teste (espessura média de 6,8 $\mu \mathrm{m}$ )

$\mathrm{Na}$ figura 15 apresenta-se a micrografia da camada ferroxidada de uma biela obtida por meio de Microscopia Eletrônica de Varredura (MEV). 


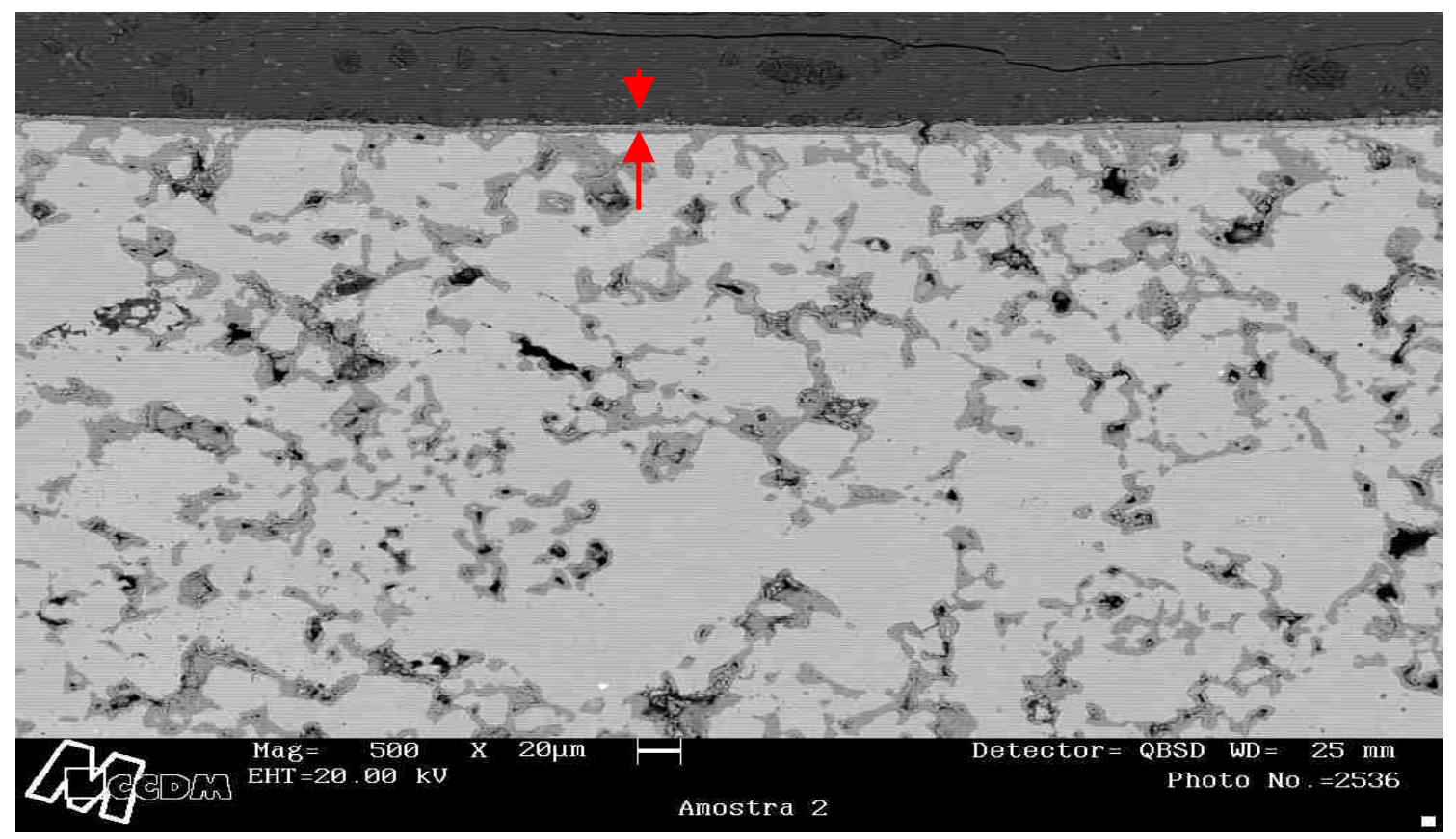

Figura 15 - Aspecto da camada ferroxidada obtida por MEV.

Verifica-se a boa uniformidade das camadas, fator este fundamental ao bom desempenho das mesmas em aplicações resistentes ao desgaste, e estas apresentaram uma espessura média de 6,8 $\mu \mathrm{m}$.

$\mathrm{Na}$ Tabela 1 são apresentados os resultados dos ensaios de durezas obtidos no substrato de ferro sinterizado

Tabela 1 - Dureza do substrato (amostra sem a camada ferroxidada)

\begin{tabular}{|c|c|}
\hline \multicolumn{2}{|c|}{ Dureza do substrato (HRB) - Carga 100Kgf } \\
\hline \multicolumn{2}{|c|}{87,3} \\
\hline & 86,8 \\
\hline & 86,9 \\
\hline & 88,3 \\
\hline & 87,9 \\
\hline & 87,9 \\
\hline & 87,4 \\
\hline \multicolumn{2}{|c|}{86,5} \\
\hline \multicolumn{2}{|c|}{0,57} \\
\hline \multicolumn{2}{|c|}{87,9} \\
\hline Média & 87,4 \\
\hline Desvio padrão & $87,43 \mathrm{HRB}=\sim 174 \mathrm{HV}$ \\
\hline \multicolumn{2}{|c|}{} \\
\hline
\end{tabular}


Na Tabela 2 são apresentados os resultados dos ensaios de microdureza realizados na seção transversal da camada obtida pela ferroxidação.

As medidas foram realizadas na seção transversal da camada, sendo realizadas 10 medidas.

Tabela 2 - Microdureza da amostra com a camada ferroxidada.

\begin{tabular}{|c|c|}
\hline Dureza da cam & e óxido $(\mathrm{HV})-$ \\
\hline & 378 \\
\hline & 413 \\
\hline & 401 \\
\hline & 339 \\
\hline & 368 \\
\hline & 413 \\
\hline & 439 \\
\hline & 439 \\
\hline & 378 \\
\hline & 413 \\
\hline Média & $398 \mathrm{HV}$ \\
\hline Desvio padrão & 32 \\
\hline
\end{tabular}

Verifica-se o aumento de dureza (130\%) em comparação com a dureza do substrato.

As amostras de óleo submetidas a ensaios Termogravimétricos (TG) foram identificadas conforme abaixo:

Amostra 1- óleo lubrificante usado para estampagem (calibragem).

Amostra 2- óleo lubrificante usado para usinagem da biela estudada neste trabalho.

Os resultados das análises são mostrados em gráficos cujas abscissas contêm os registros de temperatura (ou tempo) e a ordenada à massa residual. As curvas TG, DTG e de massa residual em função do tempo foram obtidas em um módulo termogravimétrico Hi-Res TGA 2950 (TA Instruments) acoplado a um analisador térmico TA2000 (TA Instruments).

As amostras foram aquecidas, da temperatura ambiente até $5^{\circ} \mathrm{C}$, utilizando uma razão de aquecimento de $10^{\circ} \mathrm{C} / \mathrm{min}$, se ndo mantidas nesta 
temperatura durante 1 hora.

Em seguida as amostras foram aquecidas de $5700^{\circ} \mathrm{C}$ par a $760^{\circ} \mathrm{C}$, a uma razão de $1^{\circ} \mathrm{C} / \mathrm{min}$, mantendo-se nesta temperatura por 1 hora.

Os experimentos foram realizados em cadinho de alumina, sob atmosfera dinâmica de Nitrogênio $\left(\mathrm{N}_{2}\right)$, com vazão de gás da ordem de 50L/min.

Na figura 16 apresenta-se as curvas obtidas para a amostra 1

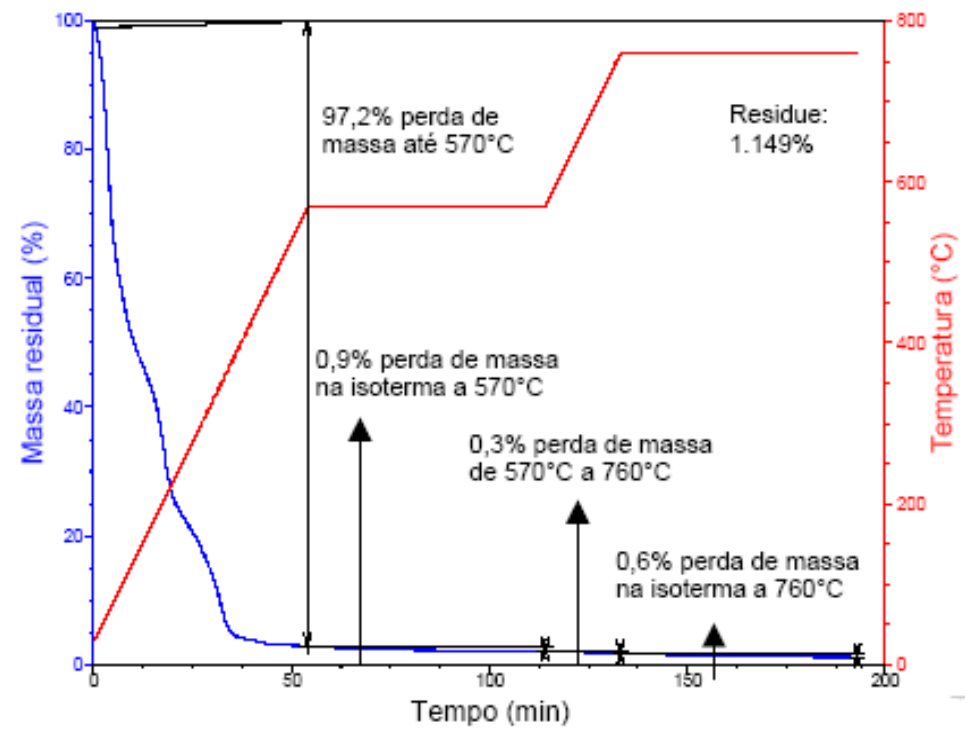

(a)

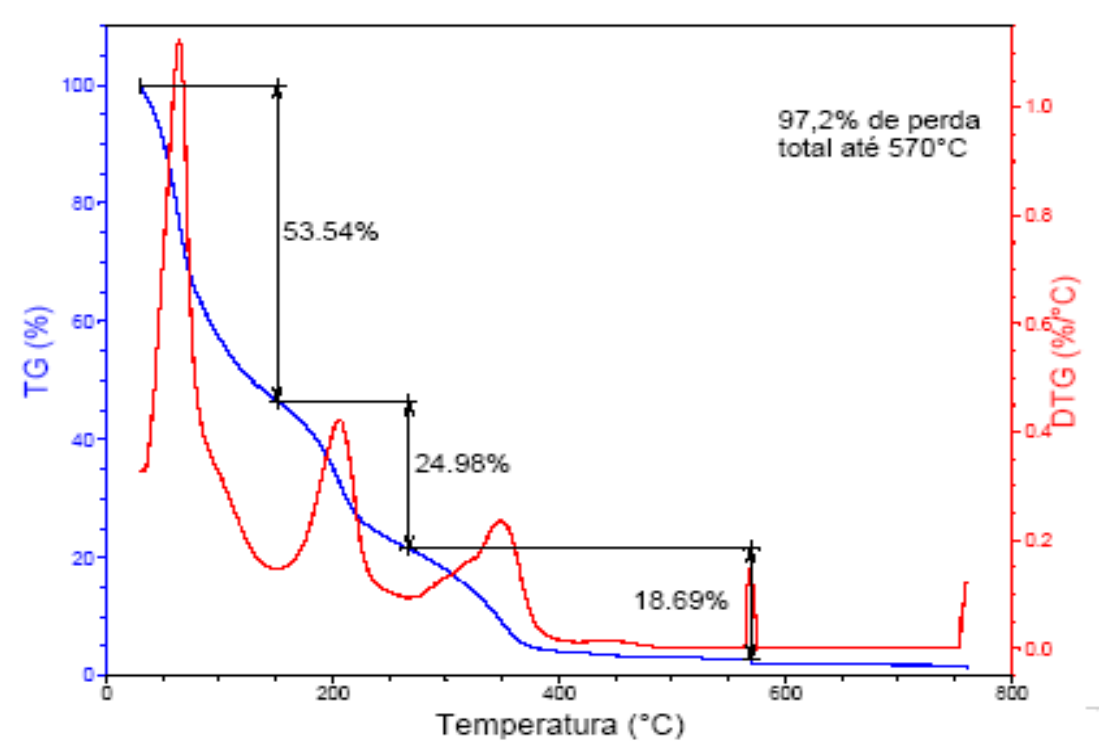

(b)

Figura 16: (a) curvas de massa residual (-----) e de Temperatura (-----) em função do tempo e (b) curvas TG (----) e DTG (----) da amostra 1. 
Observa-se na figura 16 (a) que a amostra 1 perde em torno de 97,2\% de sua massa inicial até $570^{\circ} \mathrm{C}$.

Durante a isoterma de 1 hora a $5700^{\circ} \mathrm{C}$ a amostra 1 pe rde em torno de 0,9\%. De $5700^{\circ} \mathrm{C}$ a $760^{\circ} \mathrm{C}$ ocorre uma perda de massa de aprox imadamente 0,3\%. Durante a isoterma de 1 hora a $760^{\circ} \mathrm{C}$ a amostra 1 perde em torno de $0,6 \%$. O teor de resíduos, estável a $760^{\circ} \mathrm{C}$, é de aproximadamente $1,1 \%$. A figura 16 (b) destaca por meio da curva DTG as diversas perdas de massa da amostra 1 que ocorreram até $570^{\circ} \mathrm{C}$.

Na figura 17 apresenta-se as curvas obtidas para a amostra 2

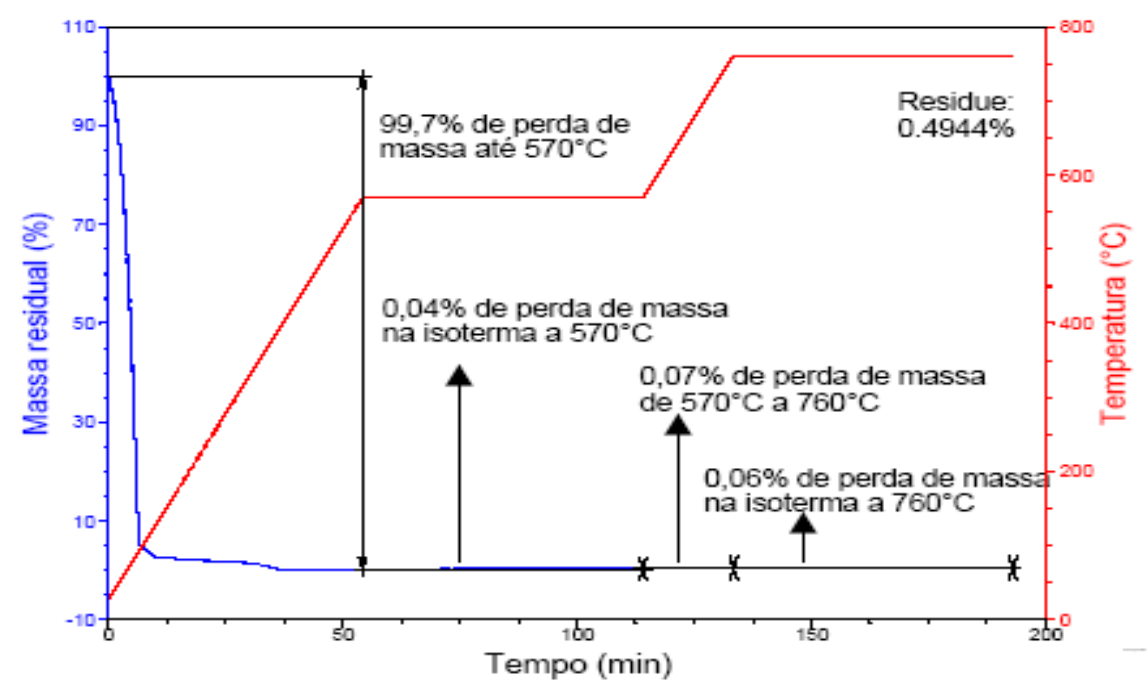

(a)

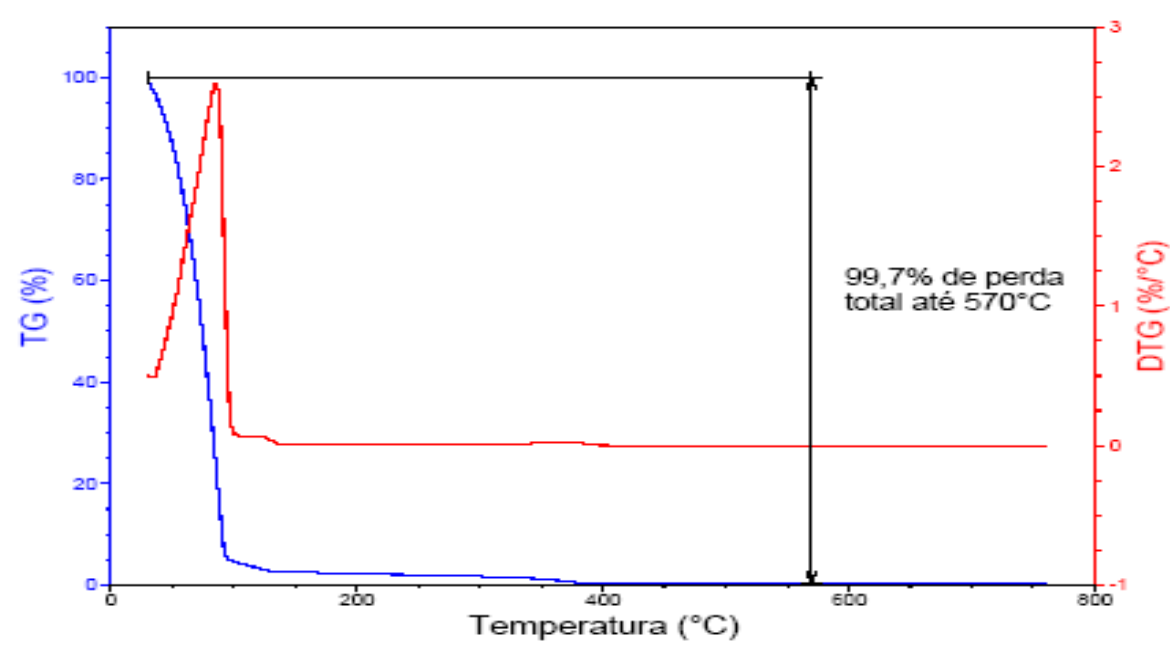

(b)

Figura 17 - (a) curvas de massa residual (-----) e de Temperatura (-----) em função do tempo e (b) curvas TG (----) e DTG (----) da amostra 2. 
Observa - se na figura 17 (a) que a amostra 2 perde em torno de 99,7\% de sua massa até $5700^{\circ} \mathrm{C}$. Durante a isoterma de 1 hora a $5700^{\circ} \mathrm{C}$ perde em torno de $0,04 \%$. De $570{ }^{\circ} \mathrm{C}$ a $760^{\circ} \mathrm{C}$ há uma perda de massa de ap roximadamente $0,07 \%$. Durante a isoterma de 1 hora a $760^{\circ} \mathrm{C}$ perde em torno de $0,06 \%$. O teor de resíduos estável a $760^{\circ} \mathrm{C}$ é de aproximadamente $0,5 \%$.

A figura 18 apresenta uma comparação entre as curvas TG das amostras 1 e 2 e a tabela 3 apresenta a composição das duas amostras.

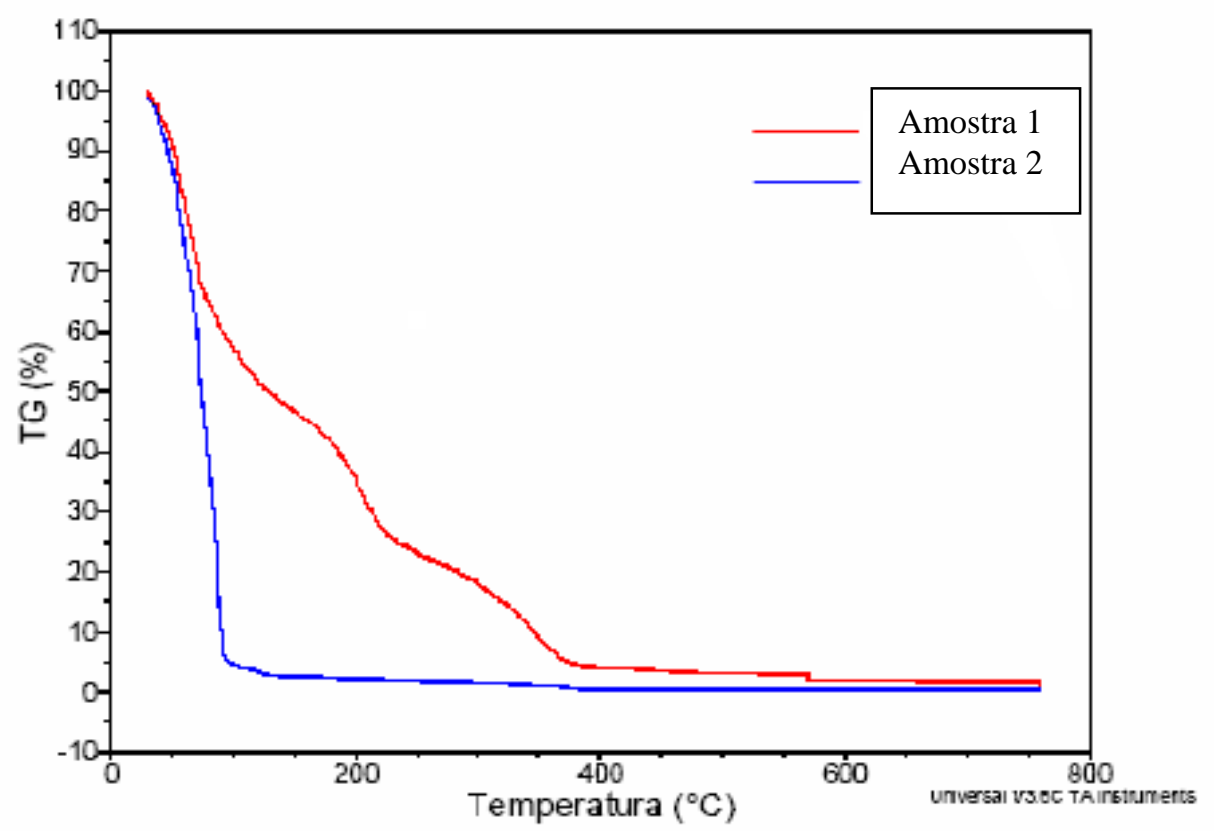

Figura 18 - comparação entre as curvas TG das amostras 1 e 2

Tabela 3 - Resumo da composição das amostras 1 e 2 após testes.

\begin{tabular}{|c|c|c|c|c|c|}
\hline \multirow{2}{*}{ Amostras } & $\begin{array}{c}\text { Perda de } \\
\text { massa até } \\
570{ }^{\circ} \mathrm{C}(\%)\end{array}$ & $\begin{array}{c}\text { Perda de } \\
\text { massa na } \\
\text { isoterma a } \\
570^{\circ} \mathrm{C}(\%)\end{array}$ & $\begin{array}{c}\text { Perda de } \\
\text { massa de } \\
570^{\circ} \mathrm{C} \text { a } \\
760^{\circ} \mathrm{C}(\%)\end{array}$ & $\begin{array}{c}\text { Perda de } \\
\text { massa na } \\
\text { isoterma a } \\
760^{\circ} \mathrm{C}(\%)\end{array}$ & $\begin{array}{c}\text { Resíduo a } \\
760^{\circ} \mathrm{C}\end{array}$ \\
\hline Amostra 1 & 97,2 & 0,9 & 0,3 & 0,6 & 1,1 \\
\hline Amostra 2 & 99,7 & 0,04 & 0,07 & 0,06 & 0,5 \\
\hline
\end{tabular}

Verifica-se no gráfico da figura 18 que no caso da amostra 2 a perda de massa residual foi de $95 \%$ a uma temperatura aproximada de $100^{\circ} \mathrm{C}$ para um tempo de exposição de 15 minutos, enquanto que no caso da amostra 1, para se perder a mesma massa residual necessitou-se uma temperatura de $380^{\circ} \mathrm{C}$ e um tempo de exposição de 40 minutos. 
Nas Figuras 19 e 20 são apresentados os aspectos das superfícies dos mancais das bielas submetidas ao ensaio no compressor em teste de funcionamento intermitente (parada e partida) durante 170 dias. Esta condição de ensaio é a mais agressiva entre as disponíveis para tal tipo de teste.

Na Figura 19 está mostrada a foto do mancal do diâmetro maior da biela sem a camada ferroxidada evidenciando desgaste após o teste.

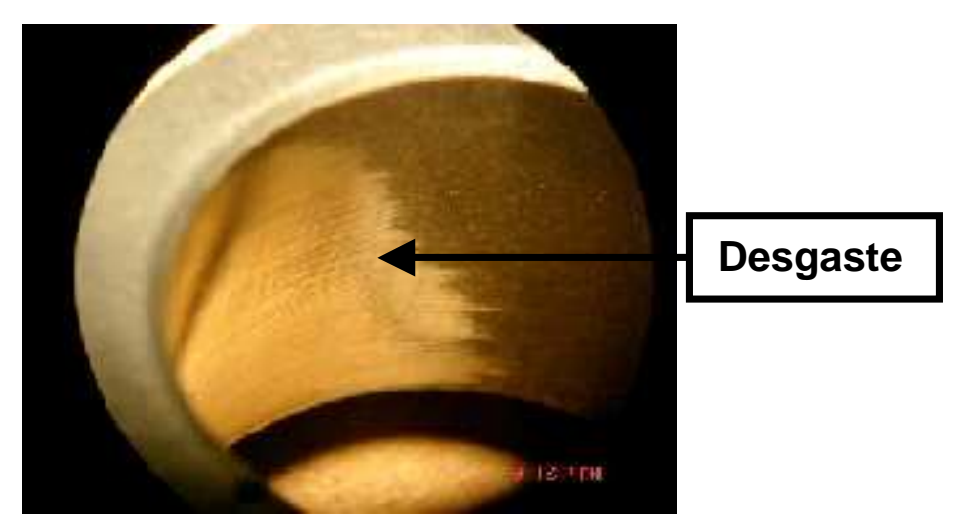

Figura 19 - Mancal da biela sem ferroxidação e com desgaste. Ampliação: 2,5X

Na Figura 20 está mostrada a foto do mancal do diâmetro maior da biela com a camada ferroxidada sem evidência de desgaste após os testes.

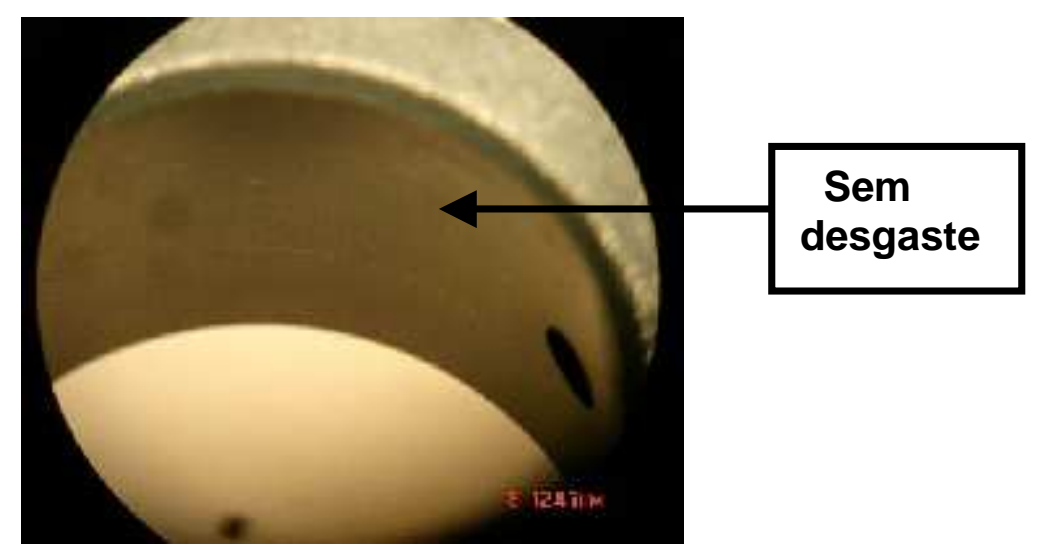

Figura 20 - Mancal da biela ferroxidada sem desgaste. Ampliação: 2,5X 
Foram realizadas medições dos perfis e circularidades em mancais da biela (diâmetro maior) para determinar o desgaste após os testes.

A Figura 21 indica o gráfico de perfil do mancal da biela sem a camada ferroxidada obtido da biela mostrada na Figura 19.

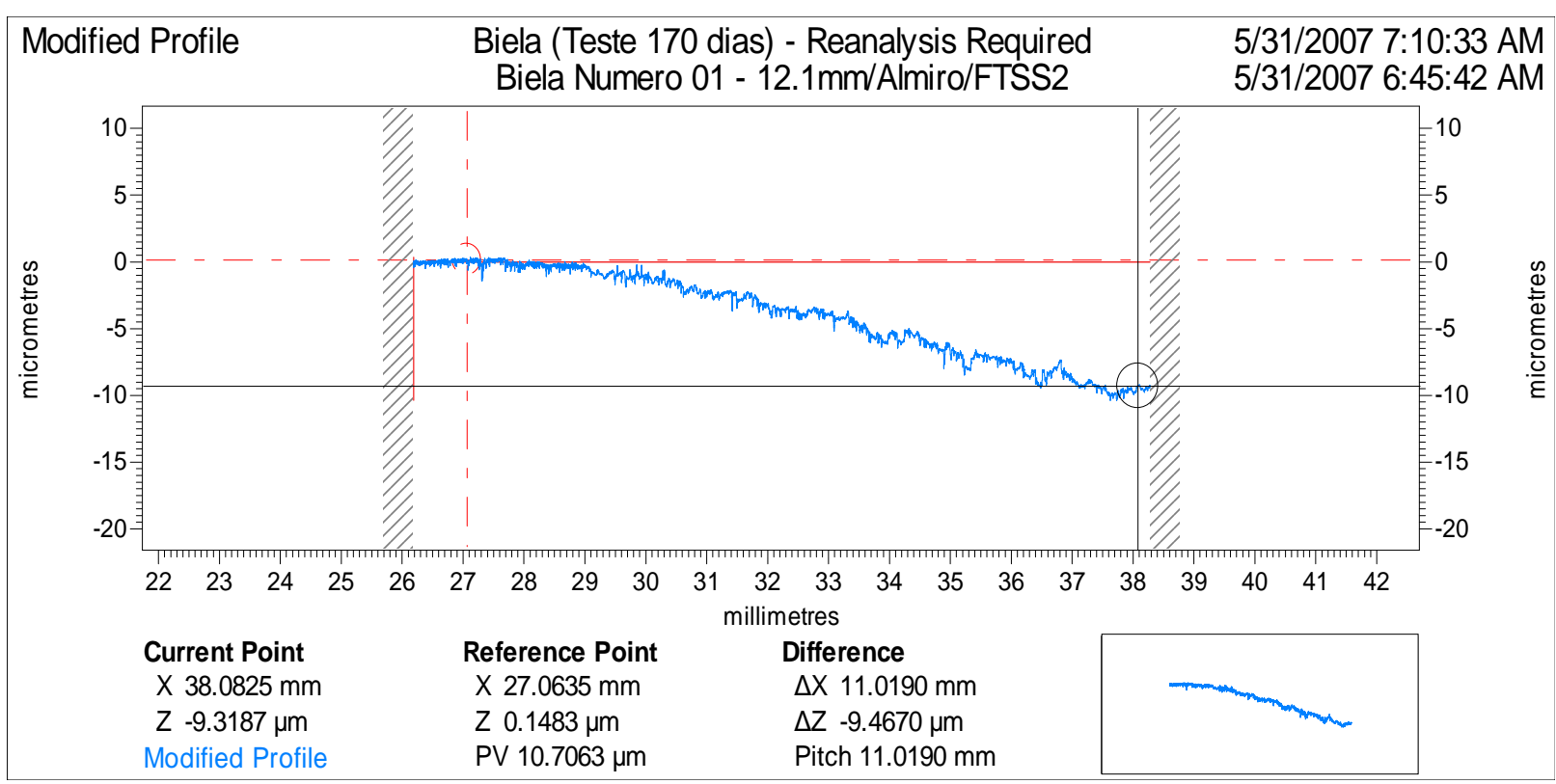

Figura 21 - Gráfico de Perfil da biela com desgaste

Verificou-se na figura 21 que ocorreu um processo de desgaste no mancal da biela (diâmetro maior) de 9,4670 $\mu \mathrm{m}$.

A Figura 22 indica o gráfico de perfil do mancal da biela com a camada ferroxidada obtido da biela mostrada na Figura 20.

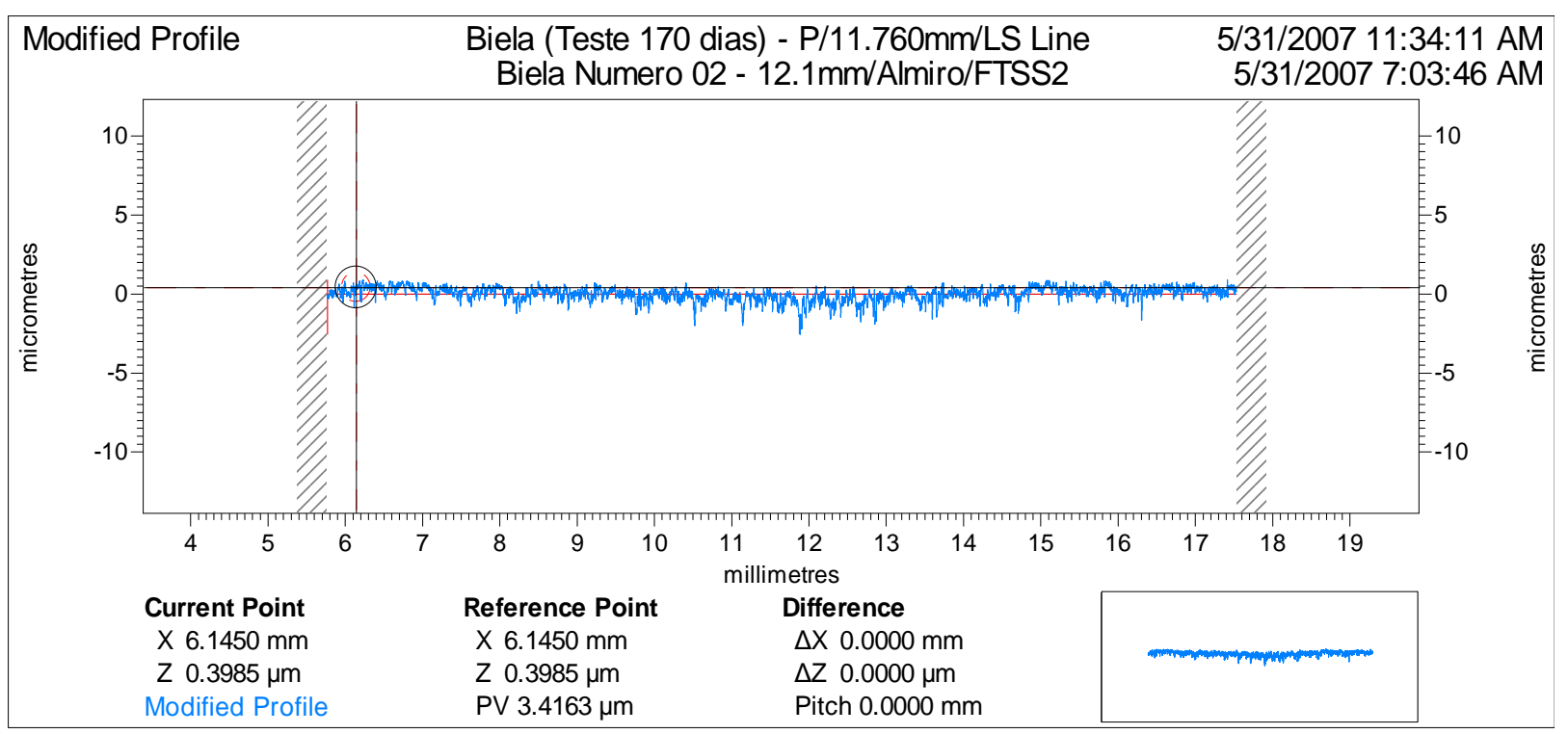

Figura 22 - Gráfico de perfil da biela sem desgaste 
Verificou-se na figura 22 que não ocorreu processo de desgaste no mancal da biela (diâmetro maior) e o valor encontrado de perfil é de $0 \mu \mathrm{m}$.

A Figura 23 indica o gráfico de circularidade do mancal da biela sem a camada ferroxidada obtido da biela mostrada na Figura 19.

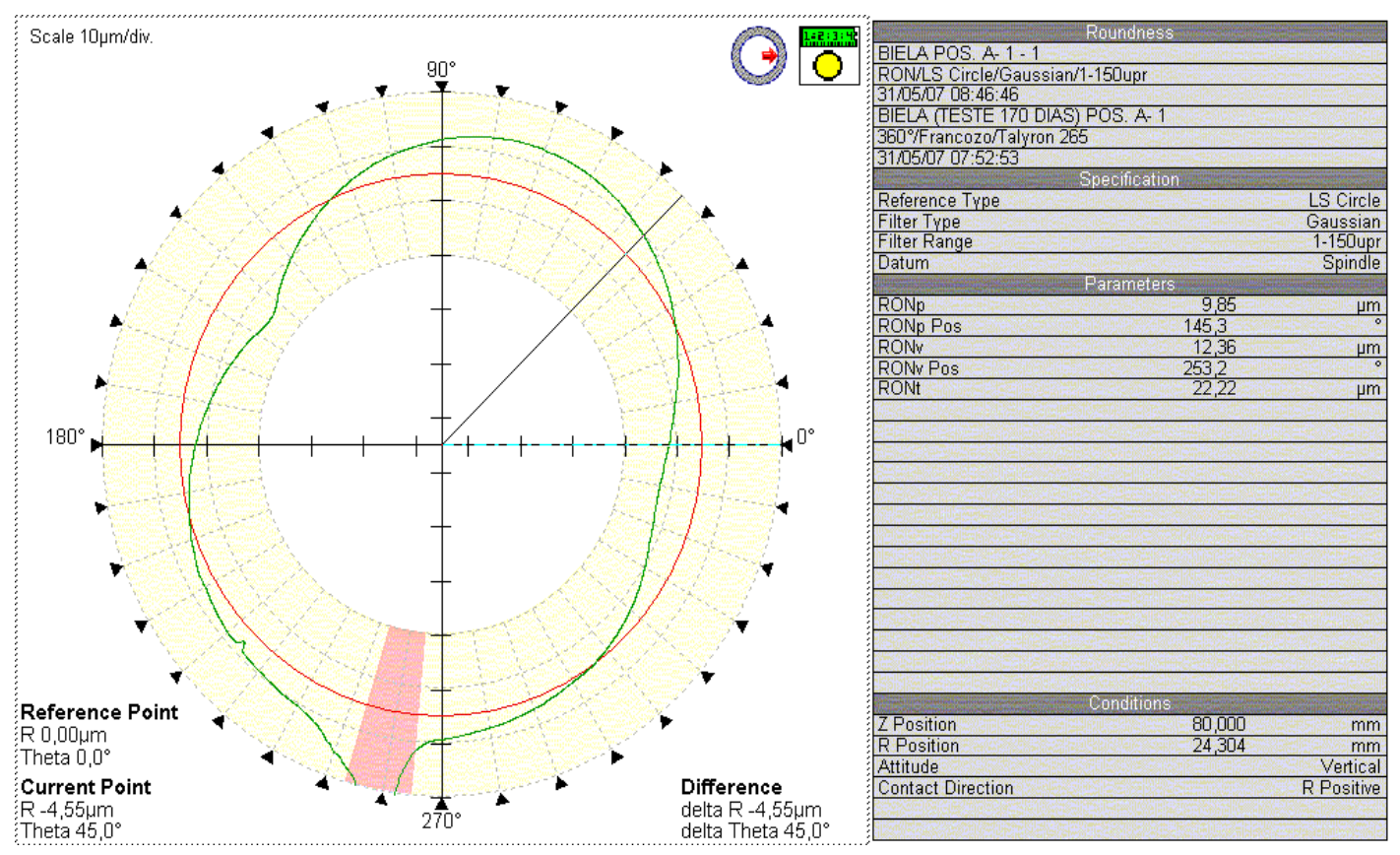

figura 23 - Gráfico de Circularidade da biela com desgaste

Verificou-se na figura 23 que ocorreu um processo de desgaste no mancal da biela (diâmetro maior). Este desgaste gerou uma deformação no diâmetro interno da biela de $22,22 \mu \mathrm{m}$.

A Figura 24 indica o gráfico de circularidade do mancal da biela com a camada ferroxidada obtido da biela mostrada na Figura 20. 


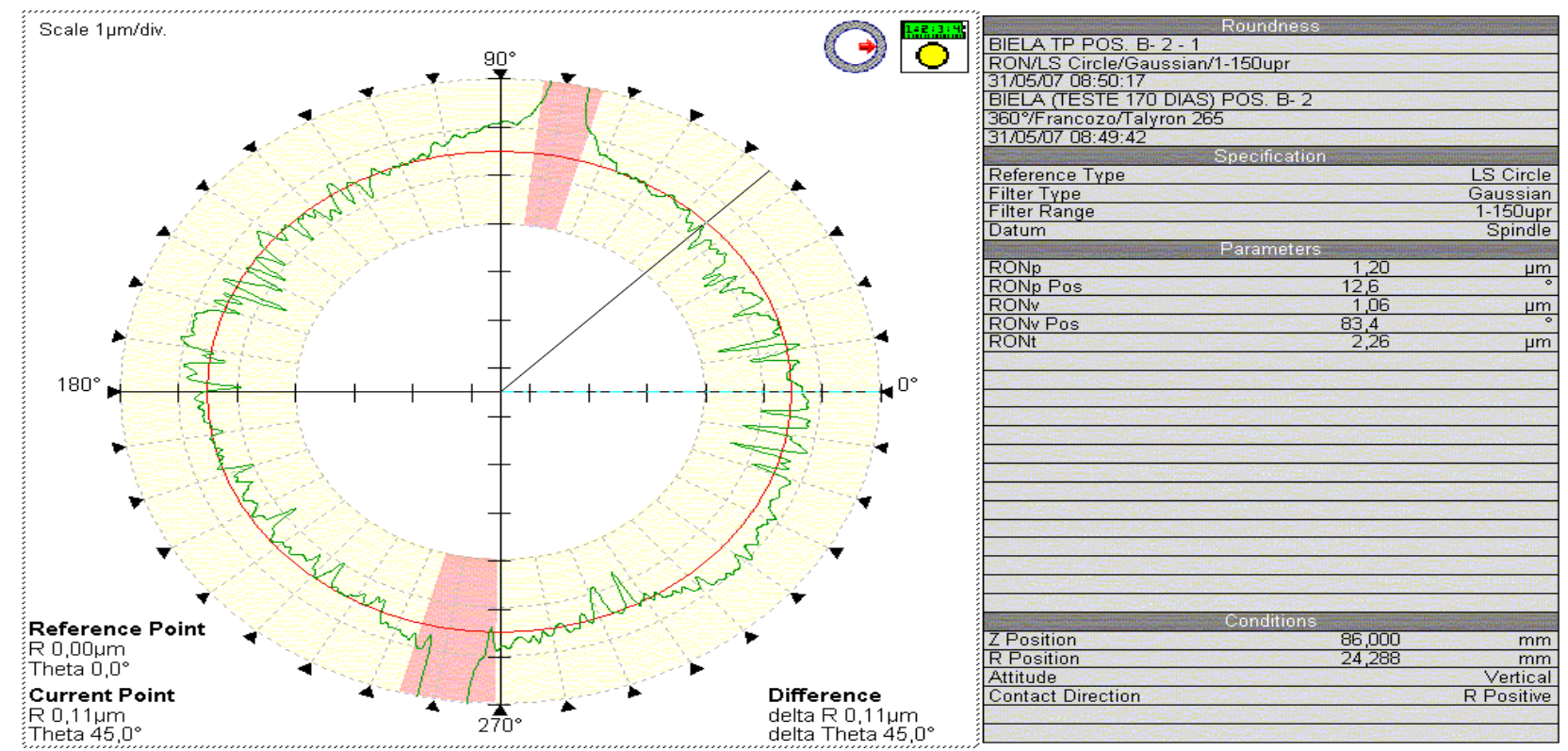

Figura 24 - Gráfico de Circularidade da biela sem desgaste.

Verificou-se na figura 24 que não ocorreu um processo de desgaste no mancal da biela (diâmetro maior). A medida do diâmetro interno da biela encontrado foi 2,26 $\mu \mathrm{m}$, perfeitamente adequado as suas condições originais.

Os gráficos de perfis e circularidades são utilizados para medir desgaste de componentes após aplicações em testes de vida acelerados e pode-se evidenciar que a diferença do mancal da biela quando aplicado em testes com a camada ferroxidada obtida pelo processo de tratamento de ferroxidação a vapor em comparação com o mancal do substrato sem a camada ferroxidada é bastante significativa, quando comparado com os valores de desgaste encontrados em teste similares, evidenciando a efetividade da ferroxidação a vapor na resistência ao desgaste.

\section{Microdesgaste com esfera presa}

Foram realizados ensaios comparativos em um equipamento de desgaste (figuras 25 e 26) onde uma esfera de aço ligado ABNT 52100 temperado girava contra o corpo de prova utilizando-se os seguintes parâmetros:

- $\quad$ Rotação da esfera = 830 RPM

- $\quad$ Carga $=10 \mathrm{~N}$

- $\quad$ Esfera $=$ diâmetro de 25,4 mm 


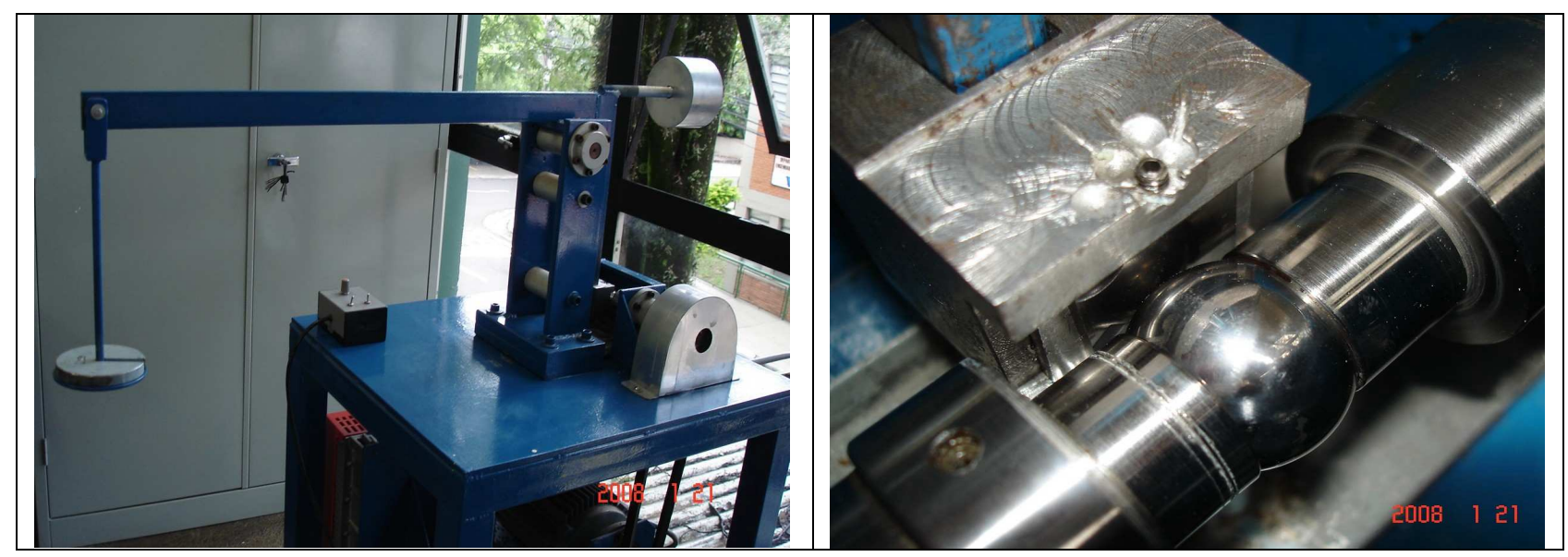

Figuras 25 e 26 - Máquina de microdesgaste com esfera presa

No período dos ensaios foram pingadas entre a esfera e a amostra gotas de óleo do mesmo tipo utilizado no compressor, a cada 30 segundos de teste.

Foram realizados ensaios com 3, 6, 9 e 12 minutos, portanto as distâncias percorridas nos ensaios foram 199,00 m, 397,00 m, 596,00 m e 794,00 m respectivamente. Os diâmetros médios das calotas foram medidos em duas posições e calculada a média dos diâmetros.

Nas figuras 27 a 30 são apresentadas as micrografias das calotas obtidas nas amostras sem a camada ferroxidada nos ensaios realizados com esfera presa.

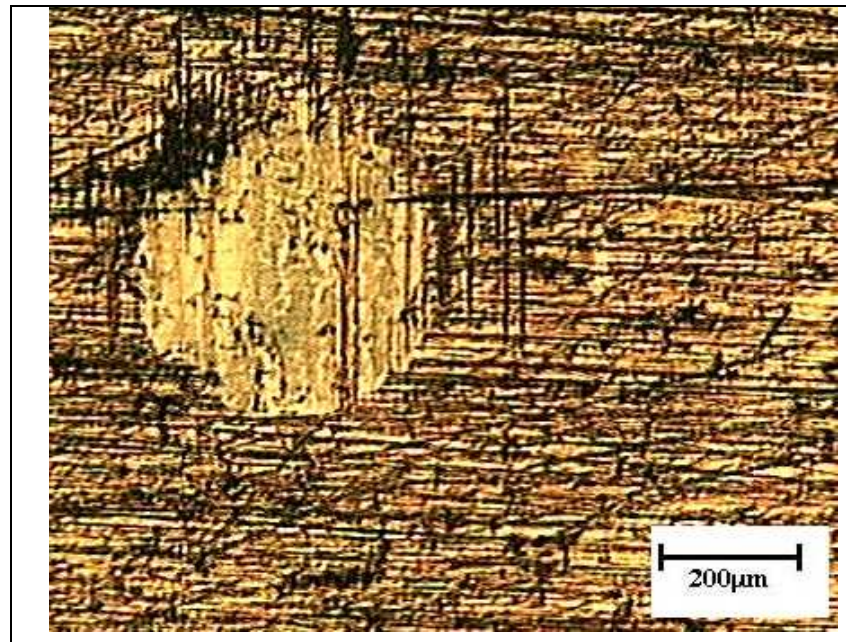

Figura 27 - Aspecto da calota obtida no ensaio de microdesgaste com esfera presa (sem camada) com óleo e distância percorrida de 199,00 m.

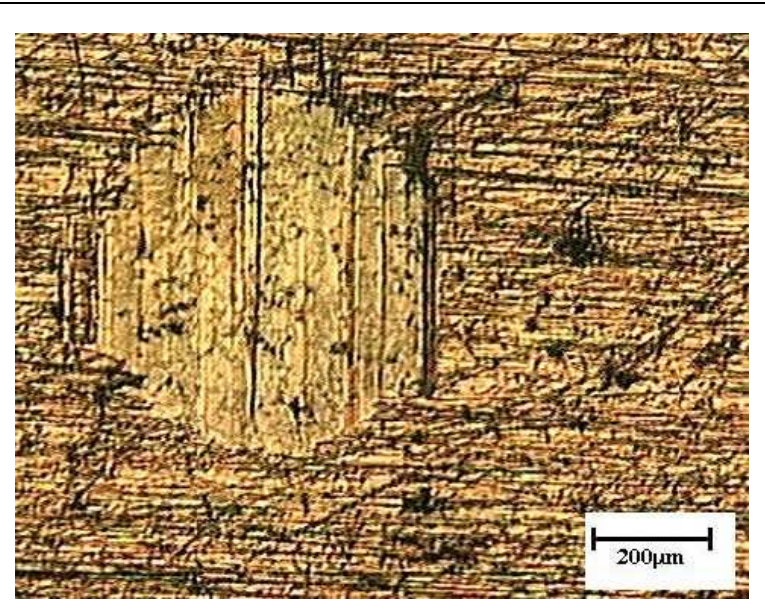

Figura 28 - Aspecto da calota obtida no ensaio de microdesgaste com esfera presa (sem camada) com óleo e distância percorrida de 397,00 m. 


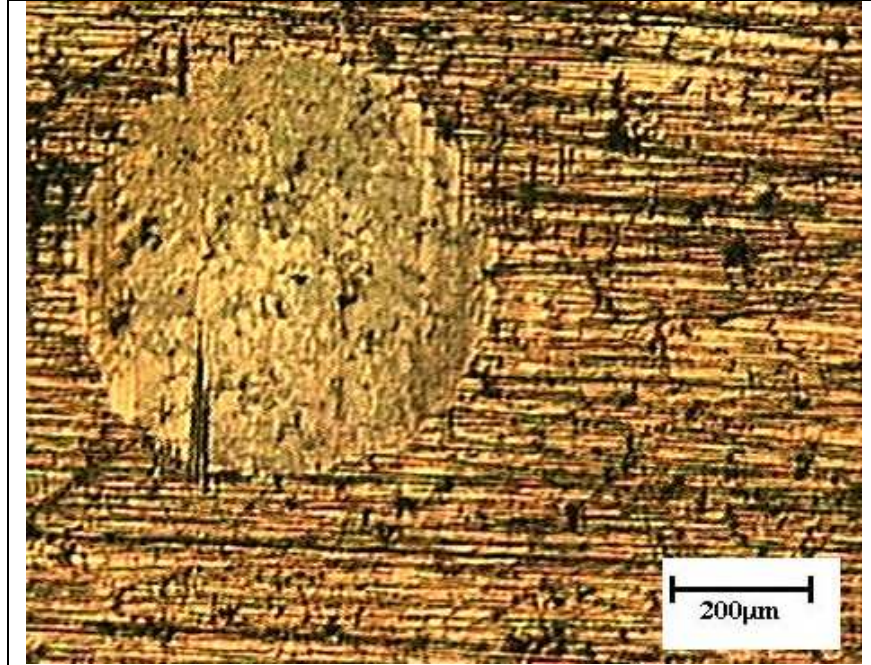

Figura 29 - Aspecto da calota obtida no ensaio de microdesgaste com esfera presa (sem camada) com óleo e distância percorrida de 596,00 m.

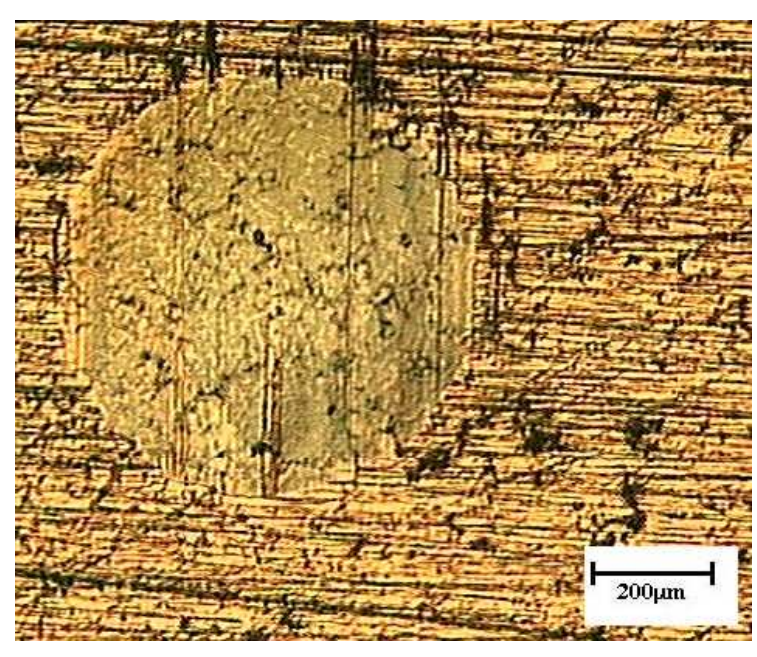

Figura 30 - Aspecto da calota obtida no ensaio de microdesgaste com esfera presa (sem camada) com óleo e distância percorrida de 794,00 m.

Nas figuras 31 a 34 são apresentadas as micrografias das calotas obtidas nas amostras com a camada ferroxidada, nos ensaios realizados com esfera presa.

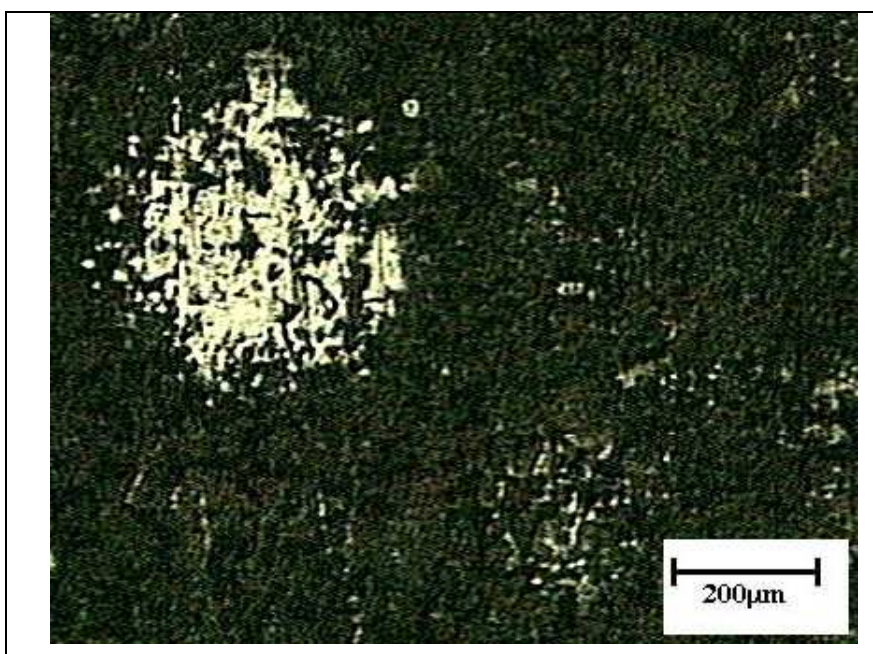

Figura 31 - Aspecto da calota obtida no ensaio de microdesgaste com esfera presa (com camada) com óleo e distância percorrida de 199,00 m.

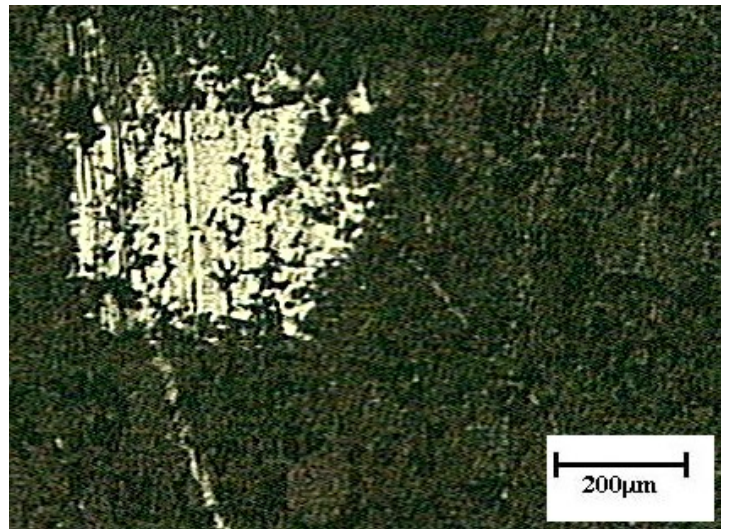

Figura 32 - Aspecto da calota obtida no ensaio de microdesgaste com esfera presa (com camada) com óleo e distância percorrida de 397,00 m. 


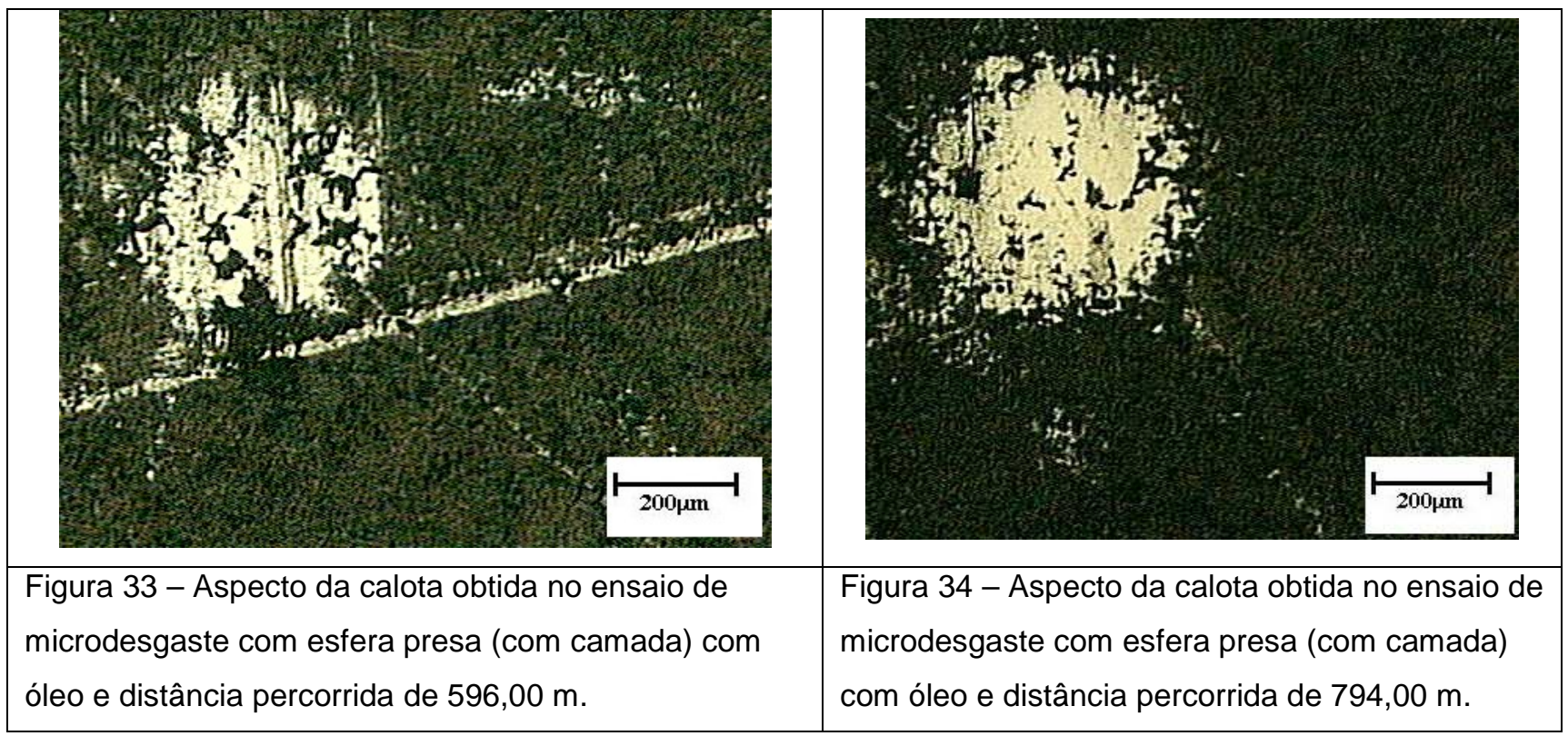

O gráfico da figura 35 indica o volume desgastado $\left(\mathrm{mm}^{3}\right)$ com relação a distância percorrida para as amostras sem camada (substrato) e a amostra com a camada ferroxidada no ensaio de microdesgaste com esfera presa.

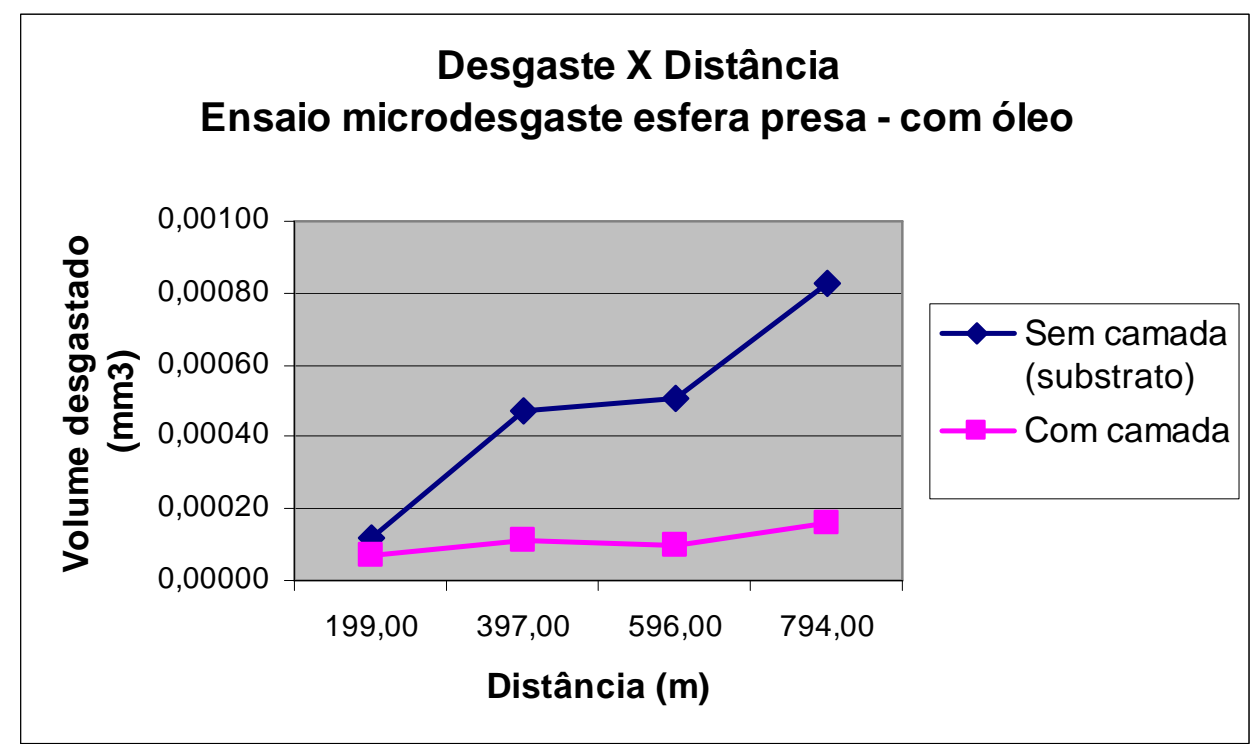

Figura 35 - Gráfico do volume de desgaste $\left(\mathrm{mm}^{3}\right)$ realizado no ensaio de microdesgaste com esfera presa tendo como lubrificante óleo.

Verifica-se a grande efetividade da ferro-oxidação da vapor (amostras com camada ferroxidada) com relação a resistência ao desgaste nestas condições de ensaio. 


\section{Microdesgaste com esfera solta}

Foram realizados ensaios comparativos em um equipamento de desgaste (figura 36) onde uma esfera de aço ligado ABNT 52100 temperado girava contra o corpo de prova utilizando os seguintes parâmetros:

- $\quad$ Rotação da esfera $=500$ RPM

- $\quad$ Peso = neste tipo de ensaio a amostra fica submetida apenas ao peso da esfera que fica girando sobre a amostra plana.

- $\quad$ Esfera = diâmetro de $25,4 \mathrm{~mm}$

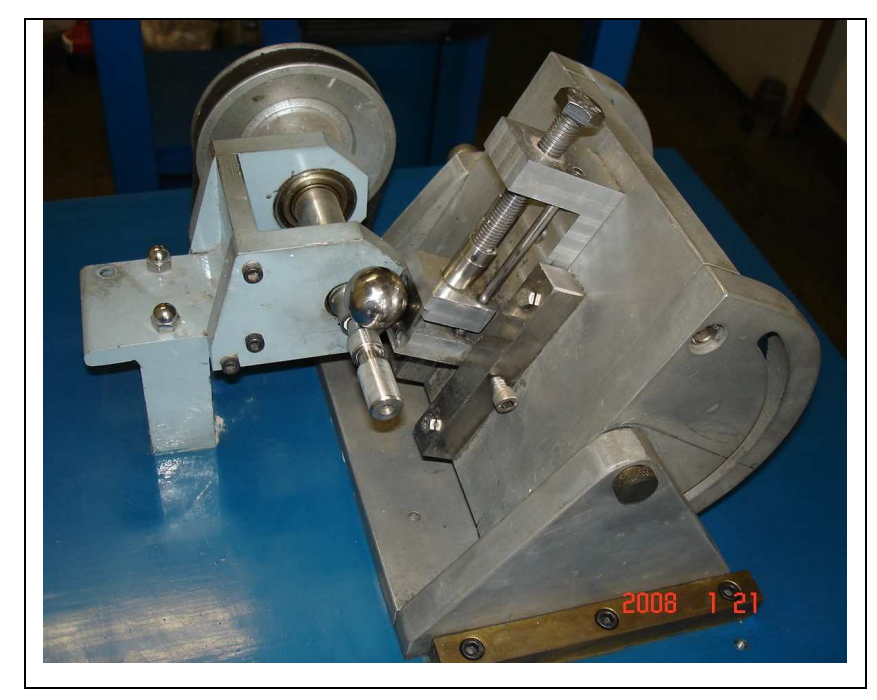

Figura 36 - Máquina de microdesgaste com esfera solta.

Este ensaio foi realizado em 3 tipos de condições:

- Ensaio com óleo (mesmo utilizado no compressor).

- Ensaio com solução de alumina com granulometria de 1,0 $\mu$ m (solução para polimento metalográfico).

- Ensaio com solução de alumina com granulometria de 5,0 $\mu \mathrm{m}$ (utilizado a proporção para mistura na quantidade de 3 partes de água destilada e 1 parte de alumina).

No período dos ensaios foram pingadas entre a esfera e a amostra gotas com algum tipo de abrasivo ou lubrificante a cada 30 segundos de teste.

Todos os ensaios de microdesgaste com esfera solta foram realizados com tempo de 2, 4, 6 e 8 minutos, portanto as distâncias percorridas nos ensaios foram $80,00 \mathrm{~m}, 160,00 \mathrm{~m}, 239,00 \mathrm{~m}$ e $319,00 \mathrm{~m}$ respectivamente.

Os diâmetros médios das calotas foram medidos em duas posições e calculada a média dos diâmetros. 
Nas figuras 37 a 40 são apresentadas as micrografias das calotas obtidas nas amostras sem a camada ferroxidada nos ensaios realizados com esfera solta utilizando óleo entre a esfera e a amostra.

\begin{tabular}{|l|l|}
\hline & \\
\hline
\end{tabular}

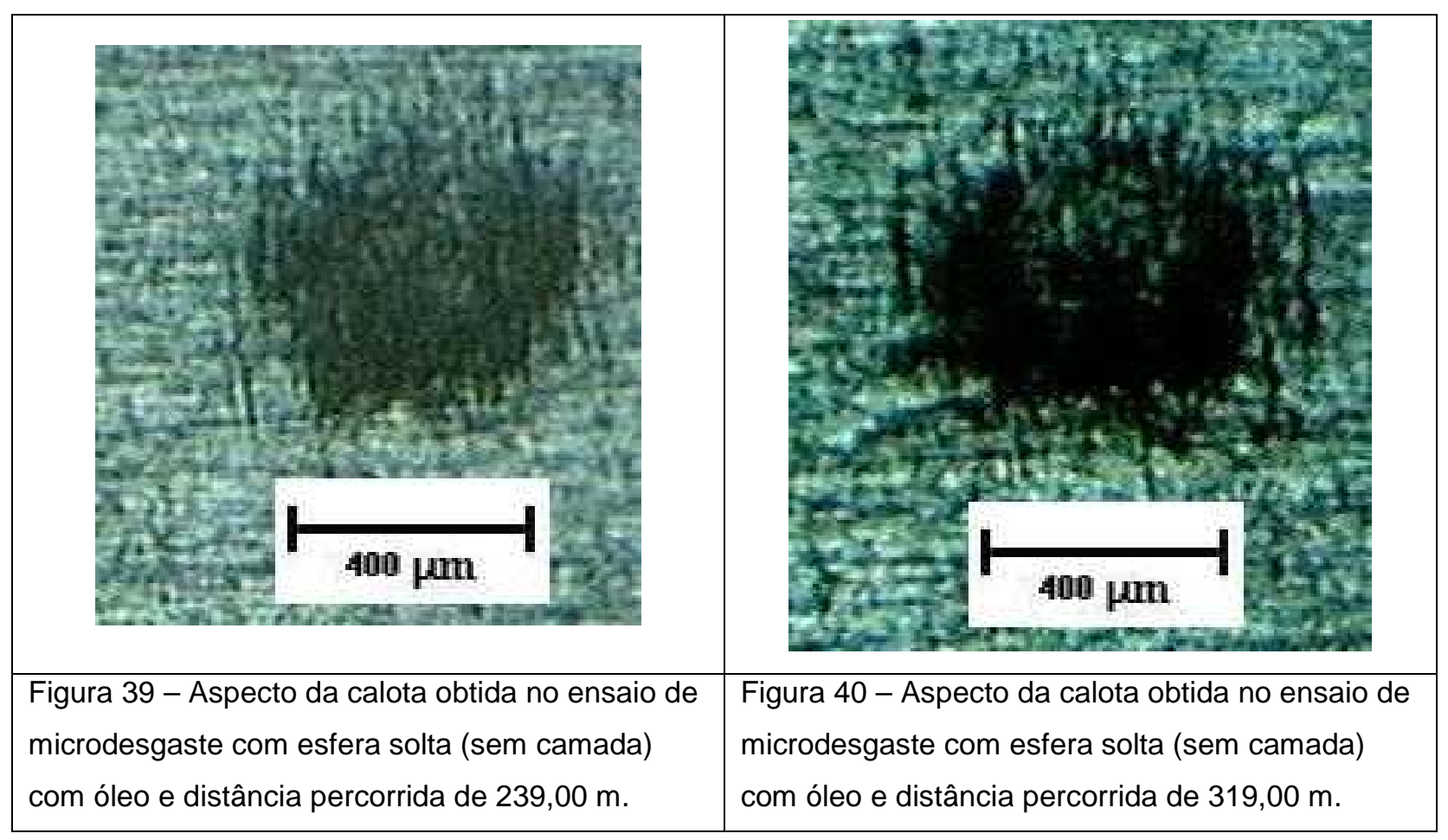


Nas figuras 41 a 44 são apresentadas as micrografias das calotas obtidas nas amostras com a camada ferroxidada nos ensaios realizados com esfera solta utilizando óleo entre a esfera e a amostra.

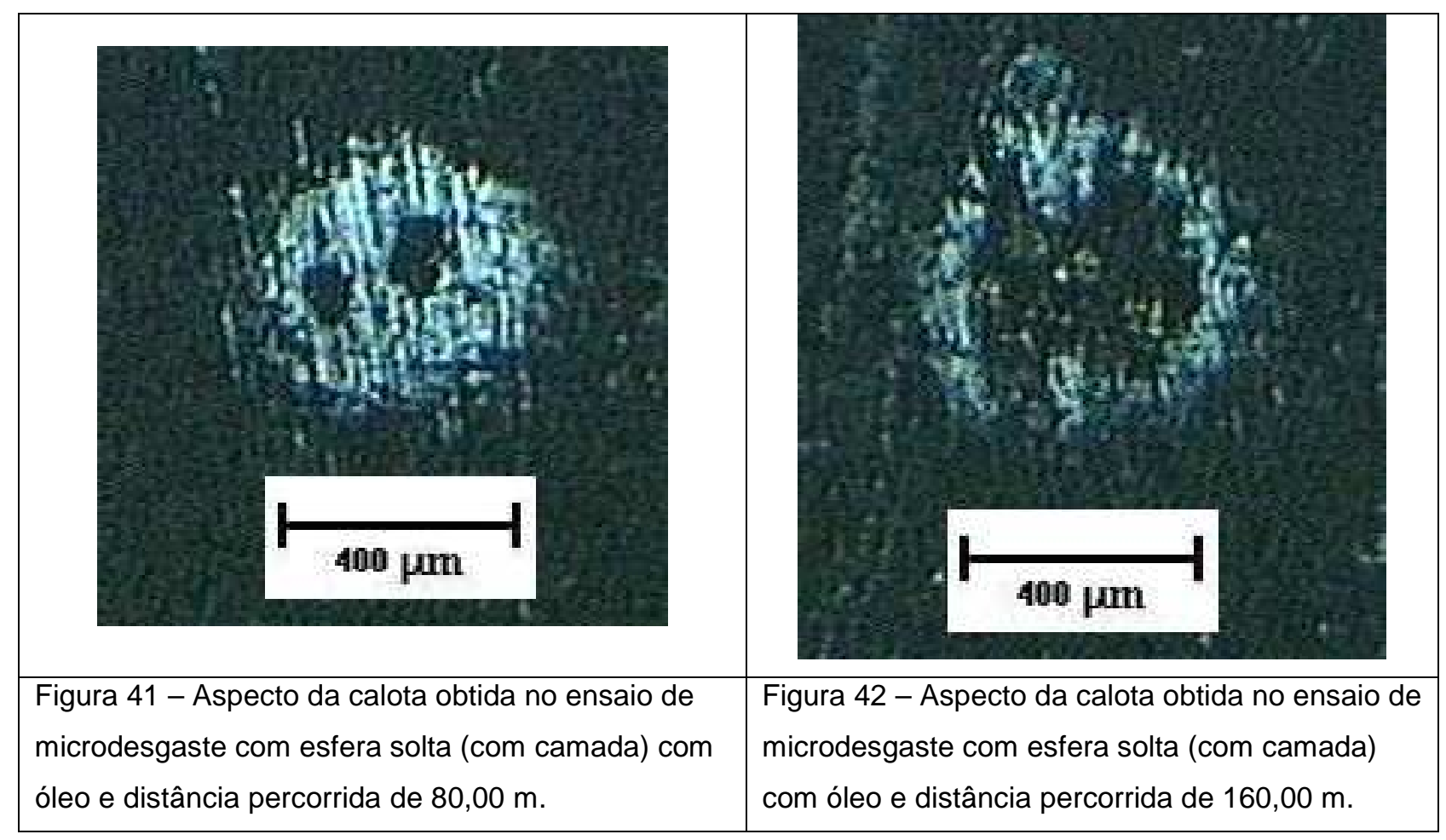

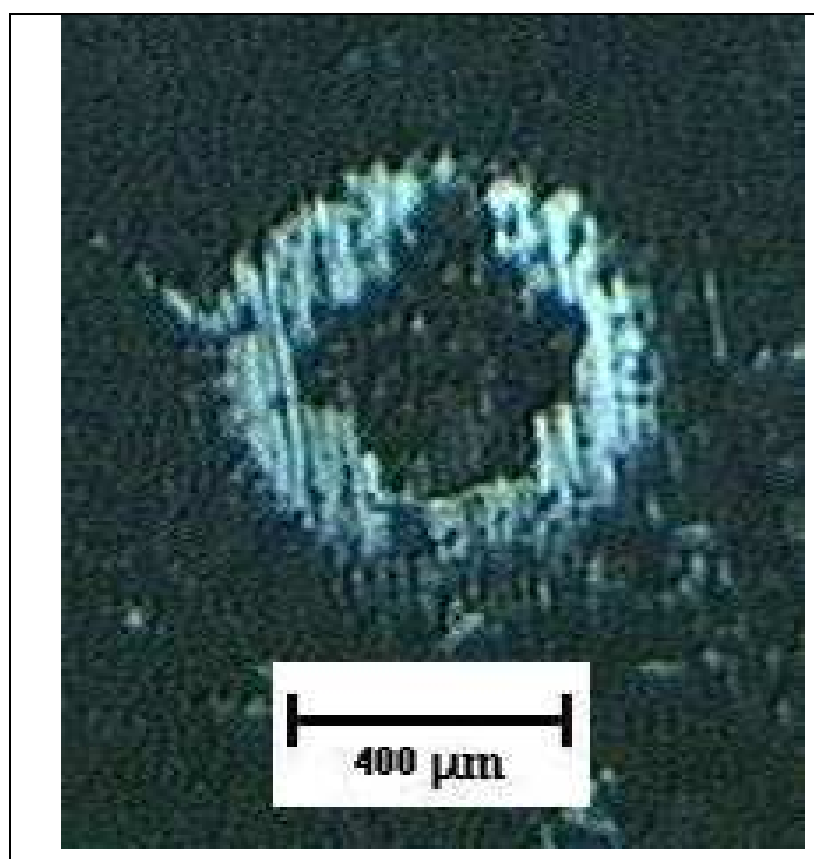

Figura 43 - Aspecto da calota obtida no ensaio de microdesgaste com esfera solta (com camada) com óleo e distância percorrida de 239,00 m.

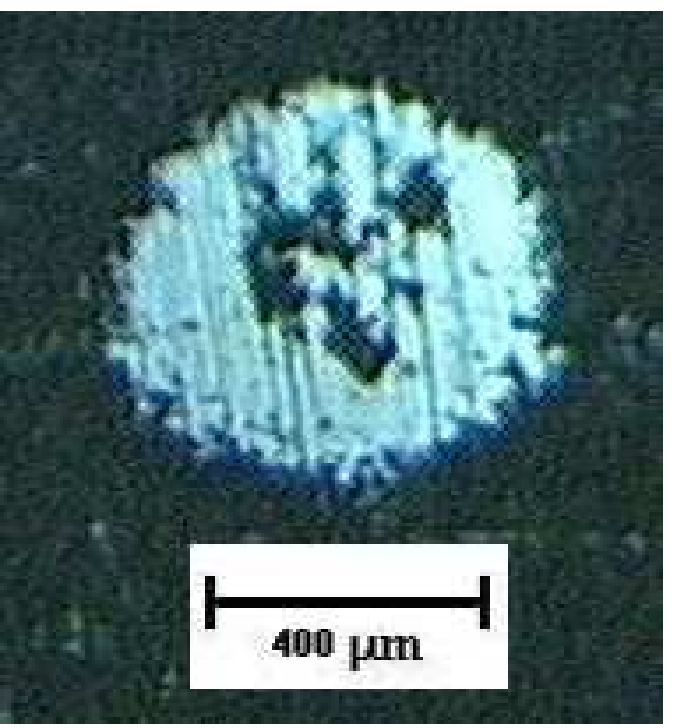

Figura 44 - Aspecto da calota obtida no ensaio de microdesgaste com esfera solta (com camada) com óleo e distância percorrida de $319,00 \mathrm{~m}$. 
O gráfico da figura 45 indica o volume desgastado $\left(\mathrm{mm}^{3}\right)$ com relação a distancia percorrida para as amostras sem camada (substrato) e a amostra com camada ferroxidada no ensaio de microdesgaste com esfera solta utilizando como lubrificante o óleo.

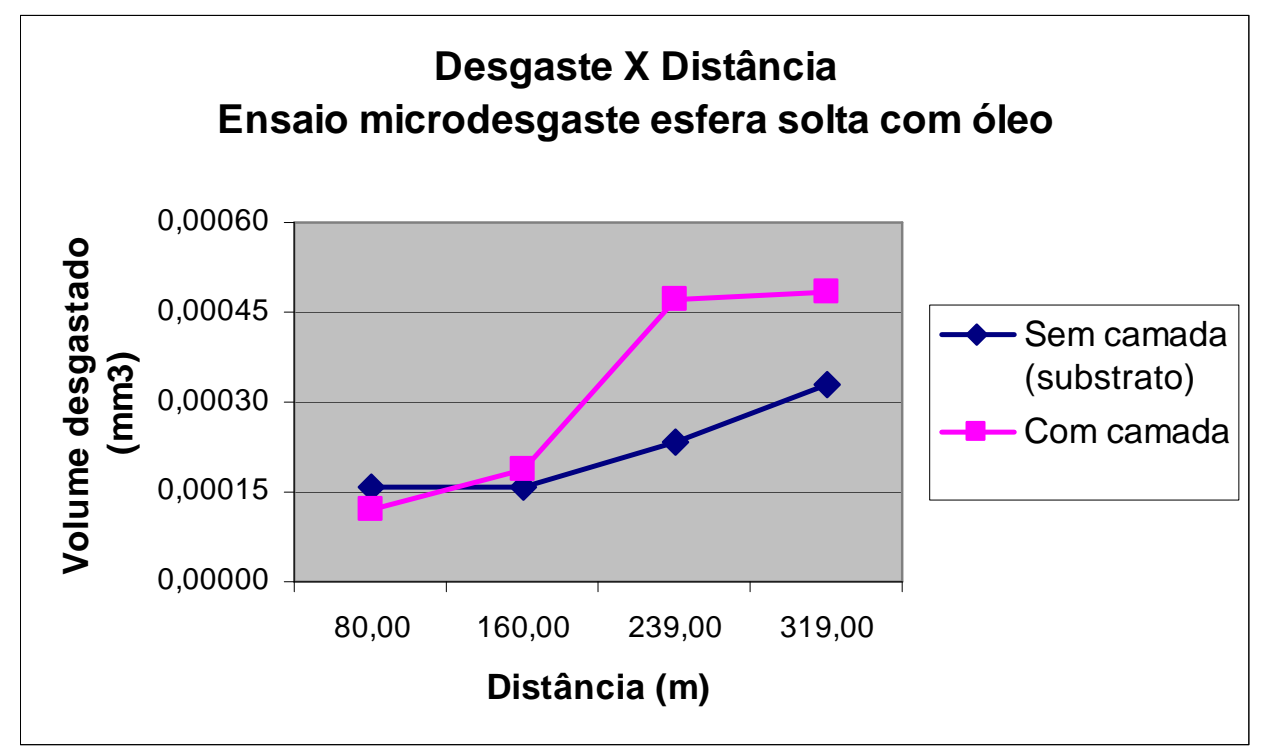

Figura 45 - Gráfico do volume de desgaste $\left(\mathrm{mm}^{3}\right)$ realizado no ensaio de microdesgaste com esfera solta e lubrificante (óleo)

Verifica-se que apesar da amostra com camada ferroxidada apresentar um desempenho inferior ao volume de desgaste, ocorre uma tendência de aproximação de desempenhos com o decorrer do ensaio. 
Nas figuras 46 a 49 são apresentadas as micrografias das calotas obtidas nas amostras sem a camada ferroxidada nos ensaios realizados com esfera solta utilizando Alumina 1,0 $\mathrm{mm}$ entre a esfera e a amostra.

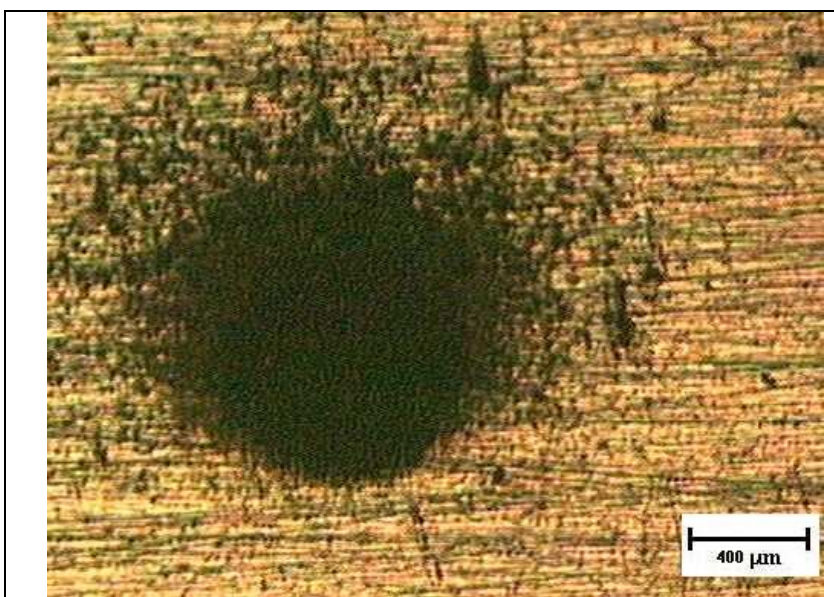

Figura 46 - Aspecto da calota obtida no ensaio de microdesgaste com esfera solta (sem camada) Alumina $1 \mu \mathrm{m}$ e distância percorrida de $80,00 \mathrm{~m}$.

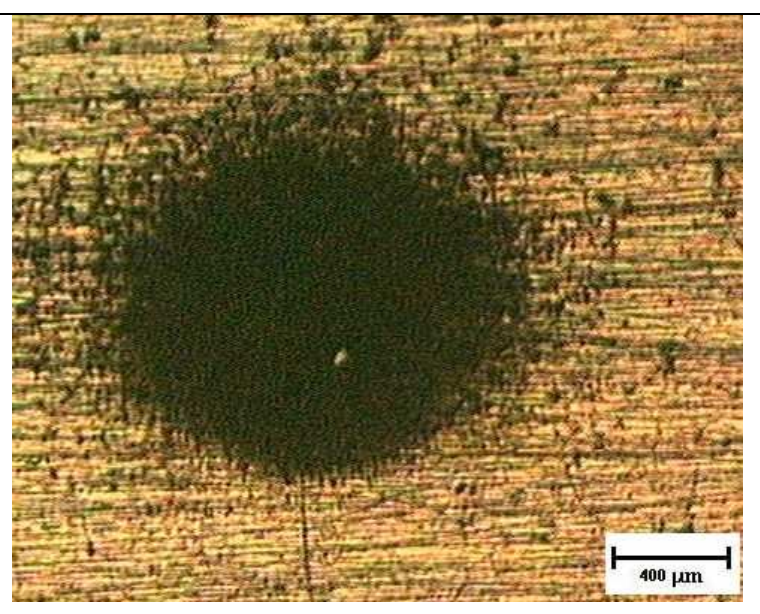

Figura 47 - Aspecto da calota obtida no ensaio de microdesgaste com esfera solta (sem camada) Alumina $1 \mu \mathrm{m}$ e distância percorrida de $160,00 \mathrm{~m}$.

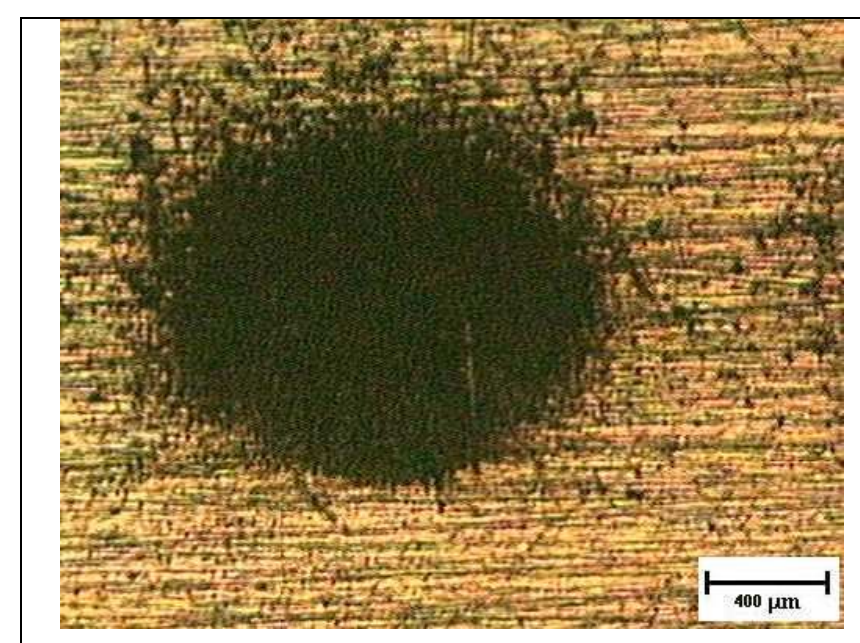

Figura 48 - Aspecto da calota obtida no ensaio de microdesgaste com esfera solta (sem camada) Alumina $1 \mu \mathrm{m}$ e distância percorrida de $239,00 \mathrm{~m}$

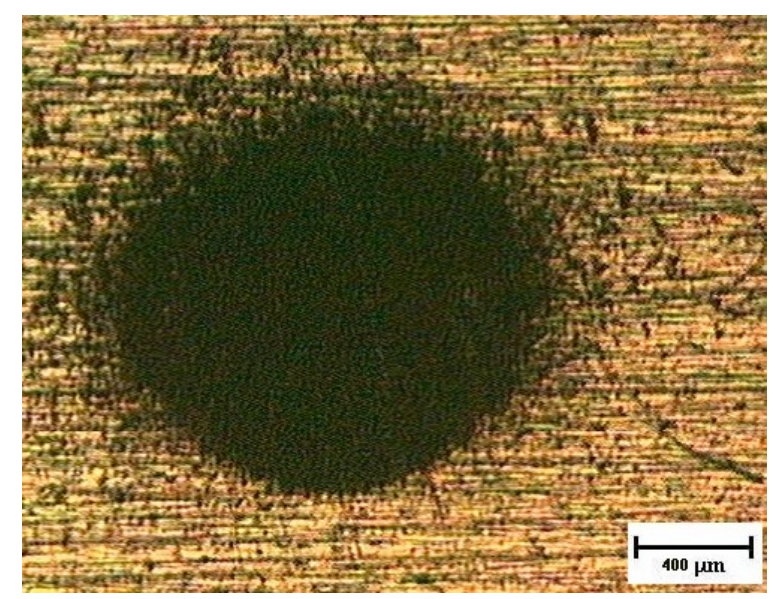

Figura 49 - Aspecto da calota obtida no ensaio de microdesgaste com esfera solta (sem camada) Alumina $1 \mu \mathrm{m}$ e distância percorrida de $319,00 \mathrm{~m}$ 
Nas figuras 50 a 53 são apresentadas as micrografias das calotas obtidas nas amostras com a camada ferroxidada nos ensaios realizados com esfera solta utilizando Alumina 1,0 $\mathrm{mm}$ entre a esfera e a amostra.

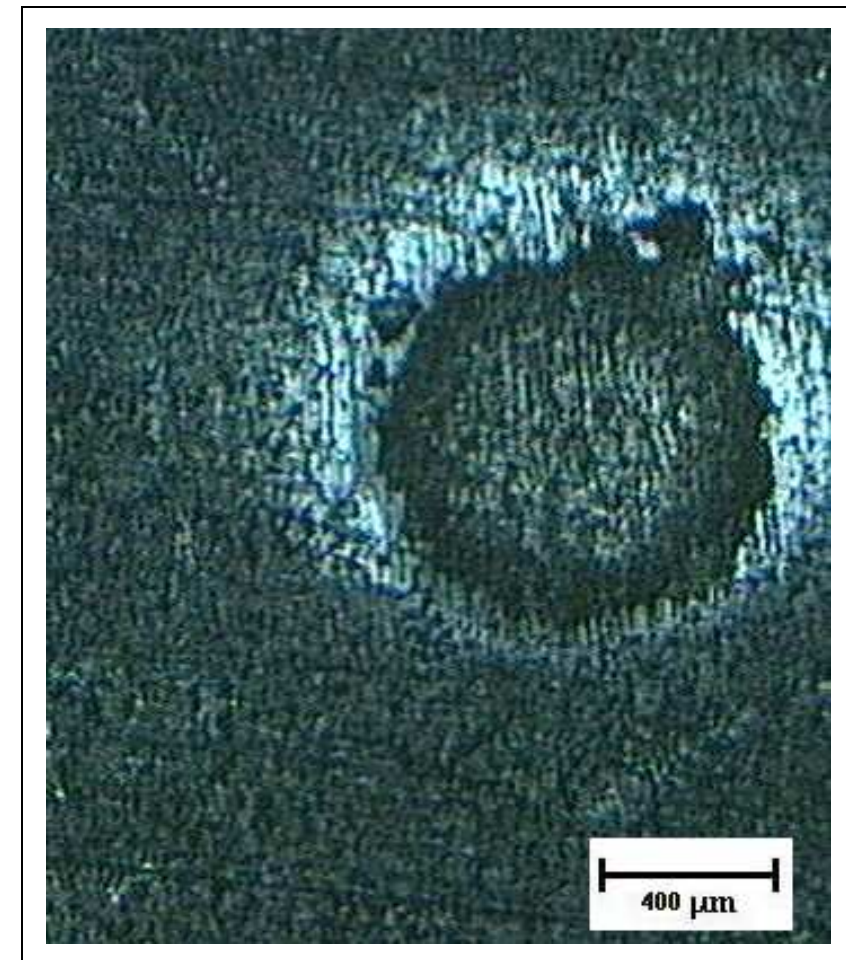

Figura 50 - Aspecto da calota obtida no ensaio de microdesgaste com esfera solta (com camada) Alumina $1 \mu \mathrm{m}$ e distância percorrida de $80,00 \mathrm{~m}$.

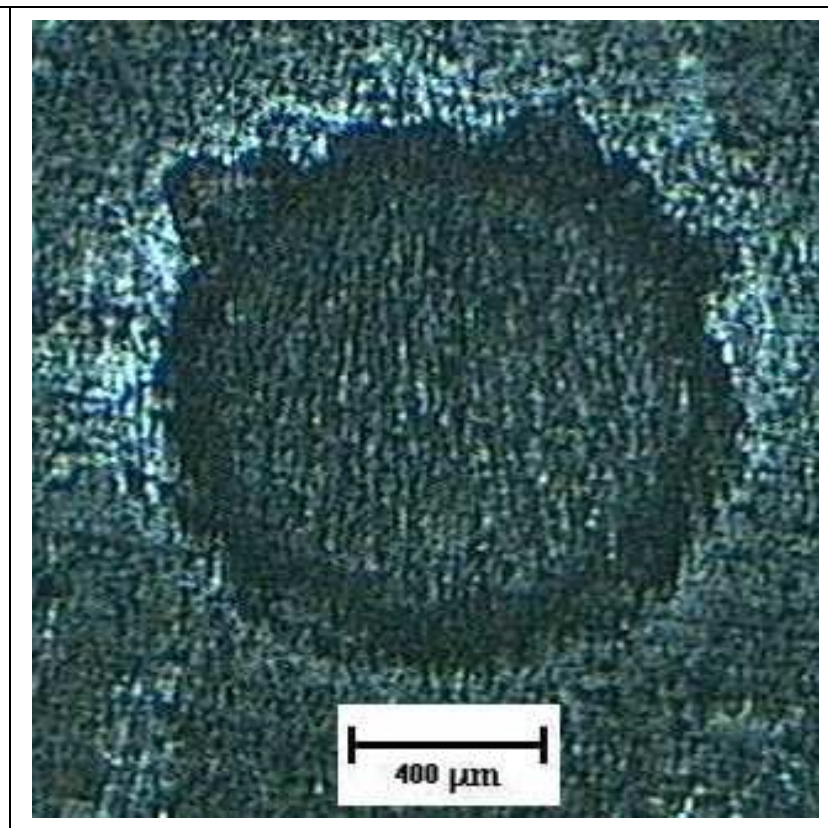

Figura 52 - Aspecto da calota obtida no ensaio de microdesgaste com esfera solta (com camada) Alumina $1 \mu \mathrm{m}$ e distância percorrida de $239,00 \mathrm{~m}$.

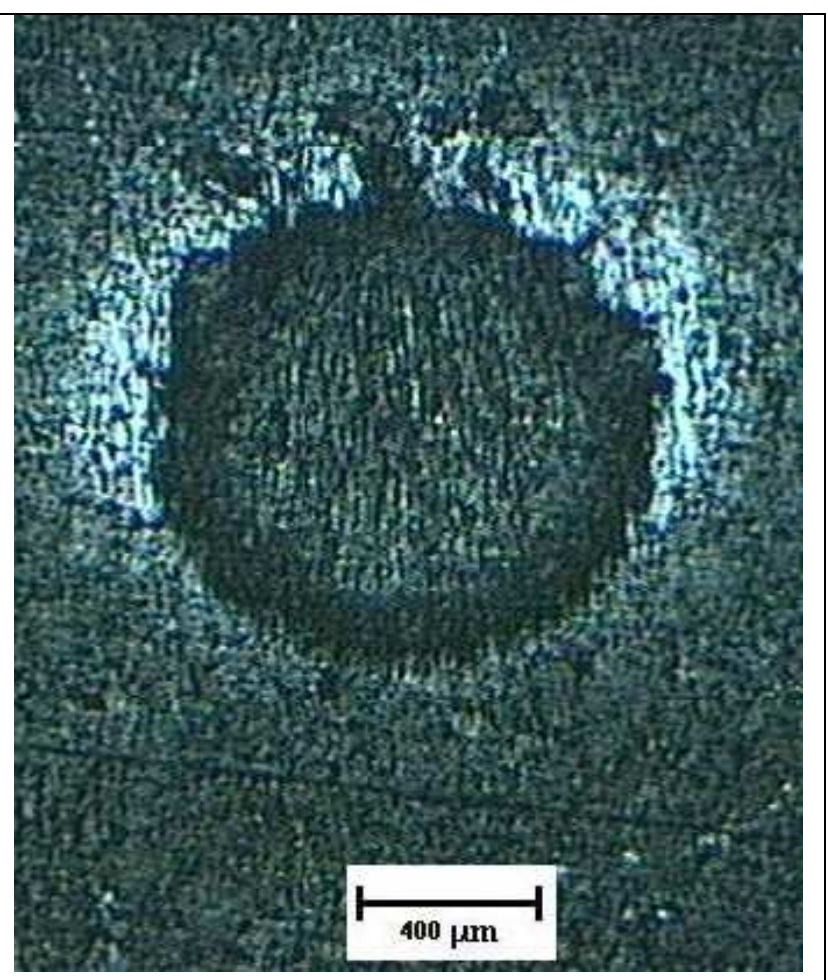

Figura 51 - Aspecto da calota obtida no ensaio de microdesgaste com esfera solta (com camada) Alumina $1 \mu \mathrm{m}$ e distância percorrida de 160,00 m.

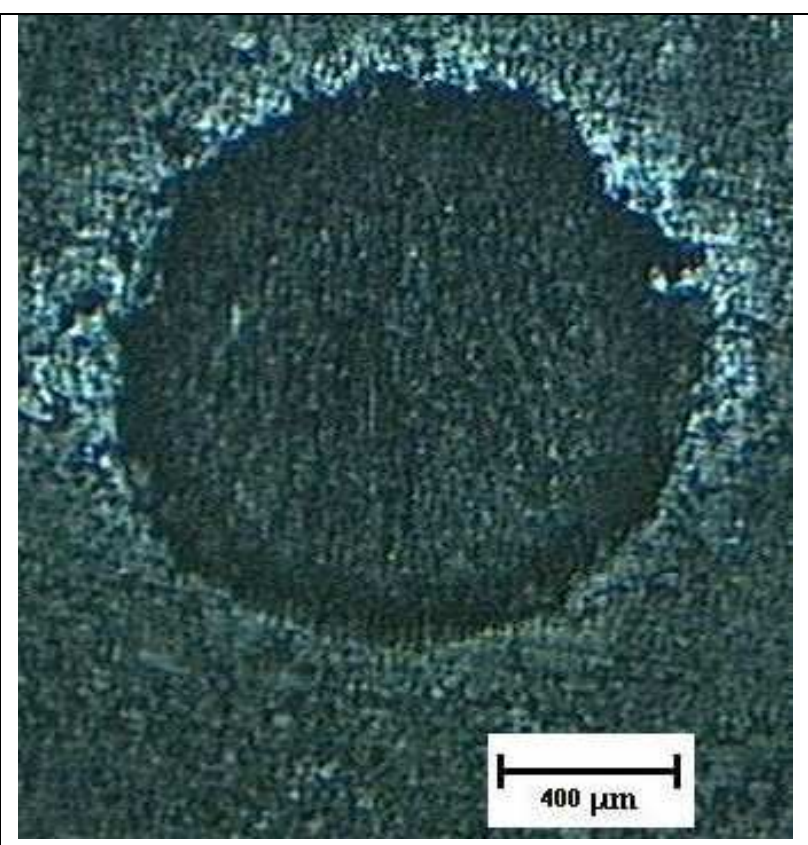

Figura 53- Aspecto da calota obtida no ensaio de microdesgaste com esfera solta (com camada) Alumina $1 \mu \mathrm{m}$ e distância percorrida de $319,00 \mathrm{~m}$. 
O gráfico da figura 54 indica o volume desgastado $\left(\mathrm{mm}^{3}\right)$ em relação a distância percorrida para as amostras sem camada (substrato) e a amostra com camada ferroxidada no ensaio de microdesgaste com esfera solta realizado utilizando como abrasivo Alumina $1 \mu \mathrm{m}$.

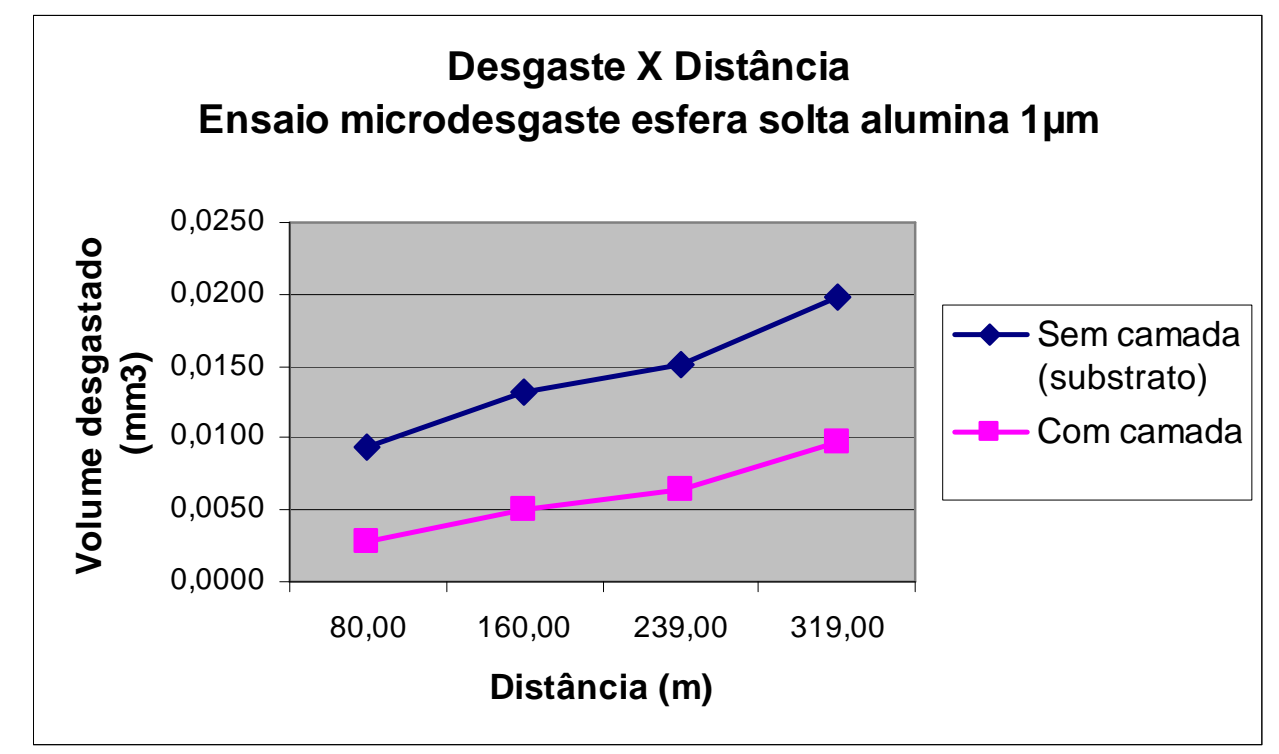

Figura 54 - Gráfico do volume de desgaste $\left(\mathrm{mm}^{3}\right)$ realizado no ensaio de microdesgaste com esfera solta e abrasivo (Alumina $1 \mu \mathrm{m}$ )

Verifica-se a efetividade da ferroxidação a vapor (amostras com camada ferroxidada) com relação à resistência ao desgaste, nestas condições de ensaio. 
Nas figuras 55 a 58 são apresentadas as micrografias das calotas obtidas nas amostras sem a camada ferroxidada nos ensaios realizados com esfera solta utilizando Alumina 5,0 $\mathrm{m}$ entre a esfera e a amostra

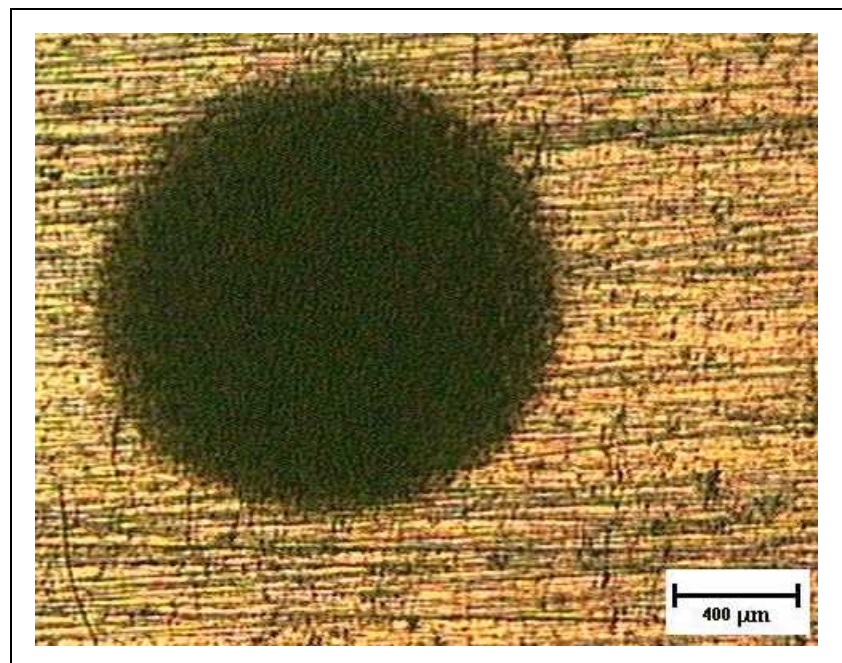

Figura 55 - Aspecto da calota obtida no ensaio de microdesgaste com esfera solta (sem camada) Alumina $5 \mu \mathrm{m}$ e distância percorrida de $80,00 \mathrm{~m}$.

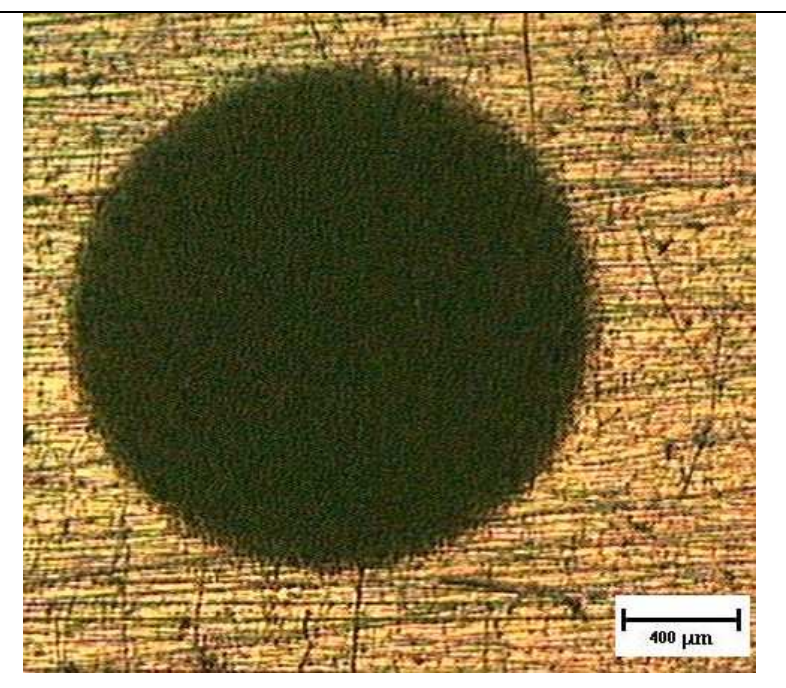

Figura 56 - Aspecto da calota obtida no ensaio de microdesgaste com esfera solta (sem camada) Alumina $5 \mu \mathrm{m}$ e distância percorrida de $160,00 \mathrm{~m}$.

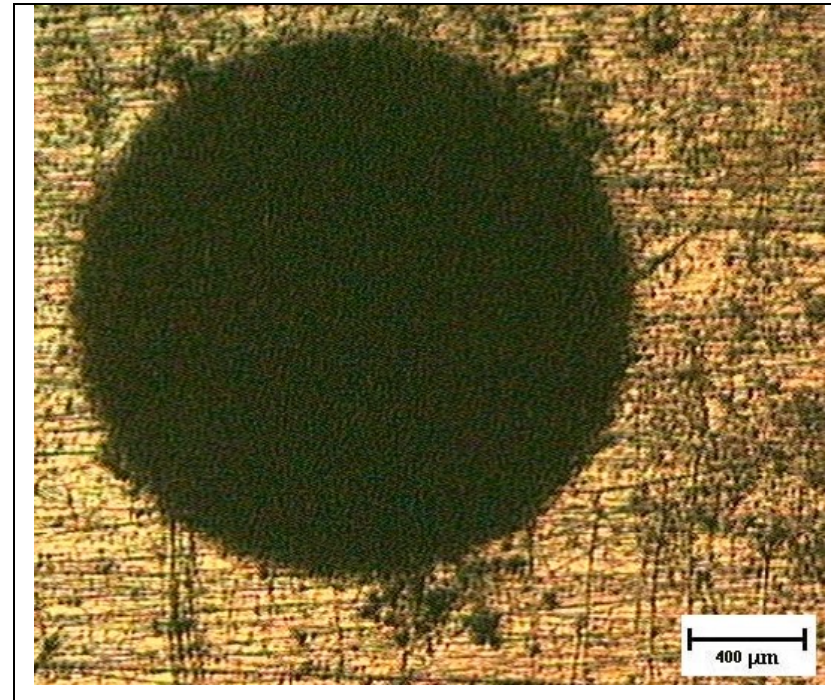

Figura 57 - Aspecto da calota obtida no ensaio de microdesgaste com esfera solta (sem camada) Alumina $5 \mu \mathrm{m}$ e distância percorrida de $239,00 \mathrm{~m}$.

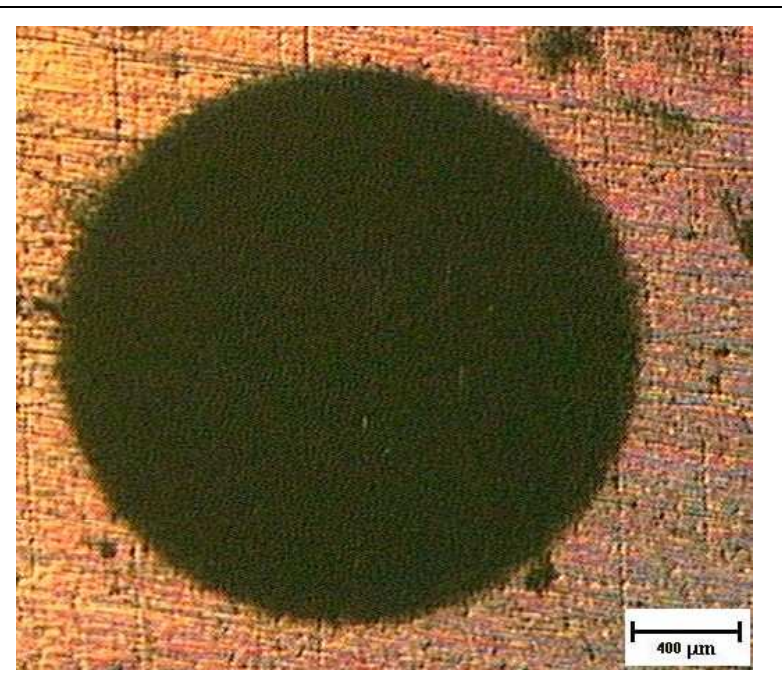

Figura 58 - Aspecto da calota obtida no ensaio de microdesgaste com esfera solta (sem camada) Alumina 5 um e distância percorrida de $319,00 \mathrm{~m}$. 
Nas figuras 59 a 62 são apresentadas as micrografias das calotas obtidas nas amostras com a camada ferroxidada nos ensaios realizados com esfera solta utilizando Alumina 5,0 $\mathrm{mm}$ entre a esfera e a amostra

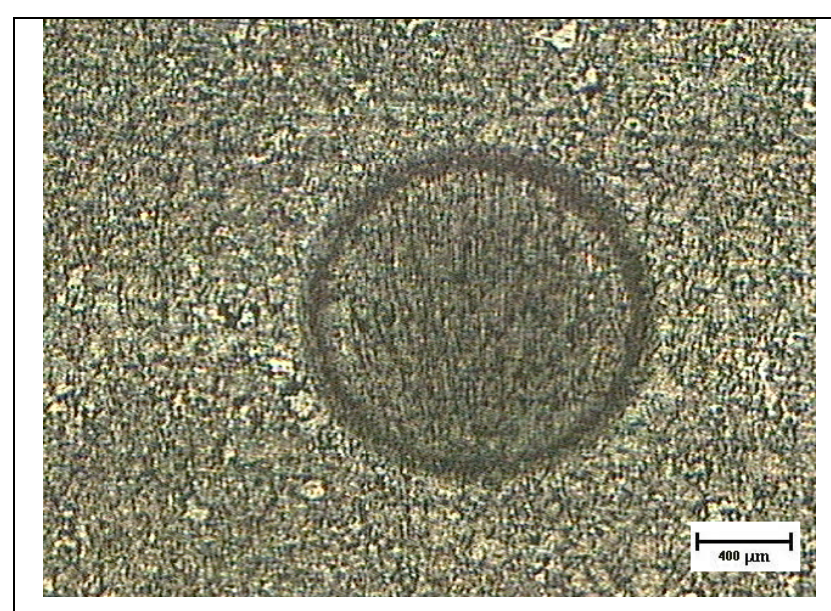

Figura 59 - Aspecto da calota obtida no ensaio de microdesgaste com esfera solta (com camada) Alumina $5 \mu \mathrm{m}$ e distância percorrida de 80,00 m.

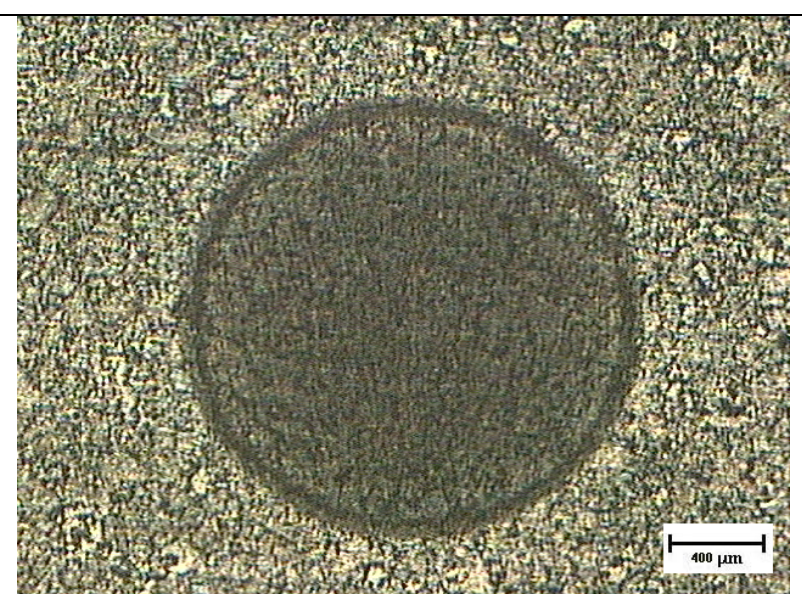

Figura 60 - Aspecto da calota obtida no ensaio de microdesgaste com esfera solta (com camada) Alumina $5 \mu \mathrm{m}$ e distância percorrida de $160,00 \mathrm{~m}$.

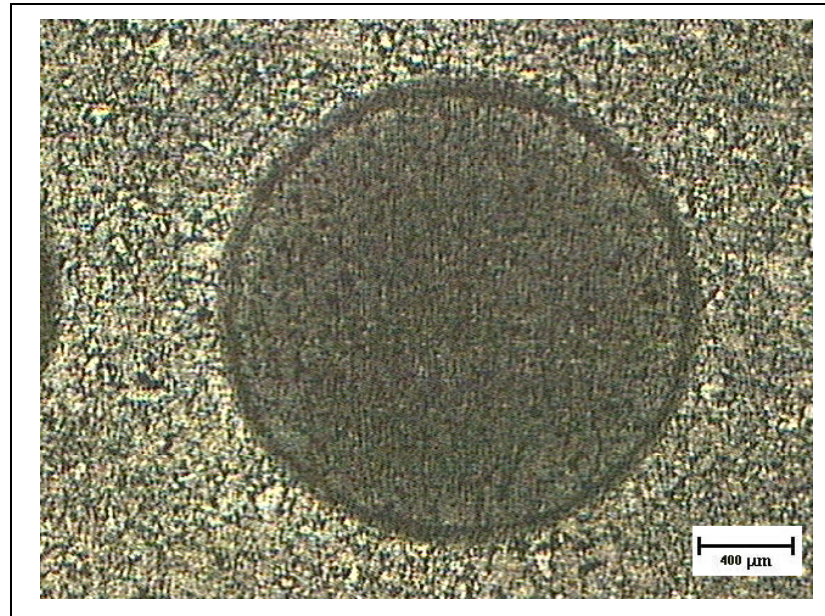

Figura 61 - Aspecto da calota obtida no ensaio de microdesgaste com esfera solta (com camada) Alumina 5 um e distância percorrida de $239,00 \mathrm{~m}$.

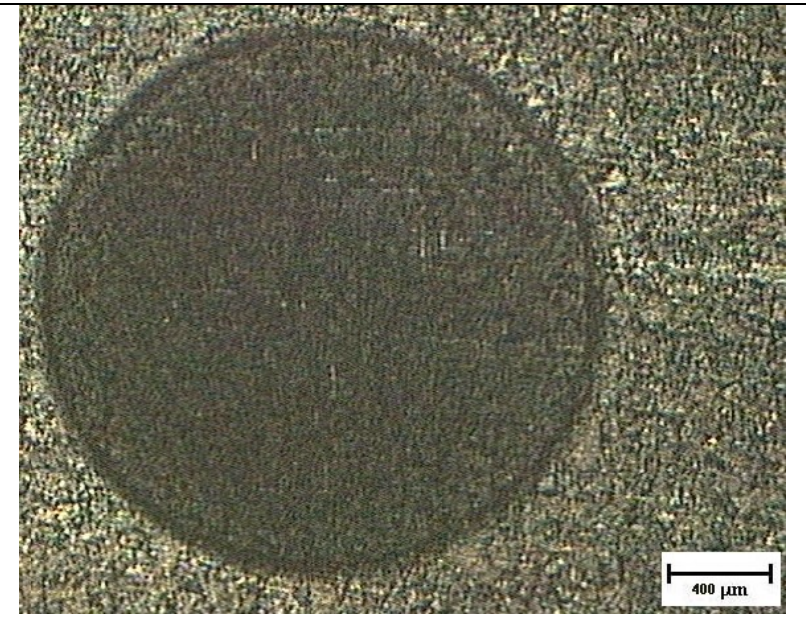

Figura 62 - Aspecto da calota obtida no ensaio de microdesgaste com esfera solta (com camada) Alumina 5 um e distância percorrida de $319,00 \mathrm{~m}$.

As auréolas verificadas ao redor das calotas referem-se às camadas ferroxidadas. 
O gráfico da figura 63 indica o volume desgastado $\left(\mathrm{mm}^{3}\right)$ com relação a distância percorrida para as amostras sem camada (substrato) e a amostra com camada ferroxidada no ensaio de microdesgaste com esfera solta utilizando como abrasivo alumina de $5 \mu \mathrm{m}$.

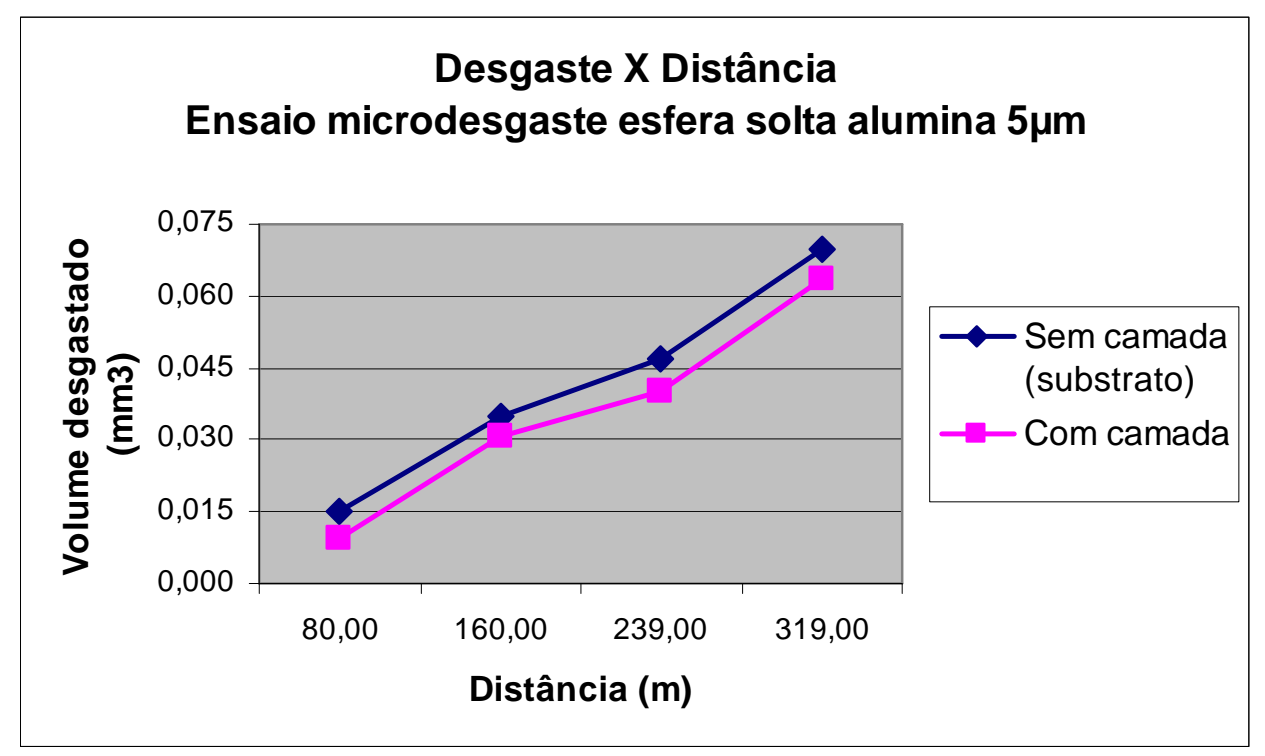

Figura 63 - Gráfico do volume de desgaste $\left(\mathrm{mm}^{3}\right)$ realizado no ensaio de microdesgaste com esfera solta e abrasivo (Alumina $5 \mu \mathrm{m}$ )

Verifica-se que a ferroxidação a vapor (amostras com camada ferroxidada) nestas condições de ensaio, foi pouco efetiva no aumento da resistência ao desgaste. 


\section{CAPÍTULO 5}

\section{CONCLUSÕES}

O tratamento de ferroxidação a vapor produziu camada com boa uniformidade e com dureza $130 \%$ superior a do substrato.

O processo de ferroxidação a vapor aplicado antes e após operação de usinagem resultou em melhoramento acentuado das propriedades de desgaste, quando aplicado em mancais de deslizamento de biela de um compressor hermético submetido a condições severas de teste de aplicação. Isto foi comprovado por meio de ensaios de perfis de desgaste, de circularidade e de microdesgaste

No ensaio de microdesgaste com esfera presa utilizando-se lubrificante entre a amostra e a esfera, que mais se aproxima das condições práticas de uso, o menor volume de desgaste foi obtido para as amostras com a camada ferroxidada, como já fora comprovado no ensaio prático.

Nos ensaios de microdesgaste com esfera solta, quando se utilizou os abrasivos (Alumina $1 \mu \mathrm{m}$ e $5 \mu \mathrm{m}$ ) entre a esfera e a amostra, as amostras submetidas ao processo de tratamento a vapor apresentaram melhores desempenhos, porém as diferenças não foram significativas.

Pode-se aplicar o processo de ferroxidação a vapor em peças usinadas, que já foram anteriormente submetidas ao mesmo processo, sem perder as suas características dimensionais originais. 


\section{REFERÊNCIAS BIBLIOGRÁFICAS}

- ANGELINI, E. et al. (2005). Effect of steam treatment on the corrosion resistance of some P/M ferrous material. Metallurgia Italiana, v.97, n.5, p.41-50.

- BEISS, P. (1991). Steam treatment of sintered parts. Powder Metallurgy, v.34, n.3, p.173-177.

- BELL, T. (1991). Surface treatments and coatings of PM components. Powder Metallurgy, v.34, n.4, p.253-257.

- BHUSHAN, B.; GUPTA, B.K. (1991). Handbook of tribology: Materials, coatings and surface treatments, McGraw-Hill, Inc., New York, USA, p.879.

- BINDER, R.; KLEIN, A. N.; GOMES, J. R. O.; ODAINAI M. (1996). Influência do processo de ferro-oxidação sobre as propriedades mecânicas de ferro sinterizado. Metalurgia \& Materiais.

- BOZZI, A.C. (2004). Obtenção e comportamento tribológico do ferro sinterizado oxidado a vapor em ensaios de desgaste por deslizamento. Tese (Doutorado) - Universidade Federal de Uberlândia, 2004.

- DA SILVA, W.M.; BINDER, R.; DE MELLO, J.D.B. (2003). Efeito do tipo de abrasivo sobre o desgaste abrasivo do ferro sinterizado e oxidado a vapor. $58^{\circ}$ Congresso anual da $\mathrm{ABM}$.

- DA SILVA, W.M.; BINDER, R.; DE MELLO, J.D.B. (2005). Abrasive wear of steam-treated sintered iron. Wear 258, p.166-167.

- DE MELLO, J.D.B.; HUTCHINGS, I.M. (2001). Effect of processing parameters on the surface durability of steam-oxidized sintered iron - Wear 250, p. $435-448$. 
- DIECKMANN, R. (1987). Diffusion of cations and of point defects in magnetite. Oxidation of metals and associated mass transport conference. p.7-28.

- EVANS, A.G.; CANNON, R.M. (1989). Stress in oxide films and relationships with cracking and spalling. Materials science forum, v.43, p.243-268.

- EYRE, T.S.; WALKER, R.K. (1976). Wear of sintered metals. Powder Metallurgy, v.1, p.22-30.

- FERRARI, A.; VERONESI, V.; GAZZANICA, G.C. (1981). A study of the influence steam treatment on tribological behavior of steel specimens. Wear, v. 66, p.355-367.

- FRANKLIN, P.; DAVIES, B.L. (1977). The effects of steam oxidation on porosity in sintered iron. Powder Metallurgy, v.1, p.11-16.

- FREITAS, E.S.R. (2006). Parâmetros topográficos para avaliação, caracterização e controle tribológico de superfície de Engenharia. Dissertação (Mestrado) - Escola de Engenharia de São Carlos, Universidade de São Paulo, São Carlos, 2006.

- GALLO, S.A.; VITIELLO, A.; PRISCO, U. (2003). On control of young's modulus of iron sintered part through steam oxidation treatment. Powder Metallurgy, v.46.

- GEE, M.G. et al. (2003). Progress towards standardization of ball cratering. Wear 255, p.1-13.

- GLADKOVA, E.N.; GUSEV, V.I. SOVETOVA, L.V. (1970). Structure of oxide films resulting from vapor thermal oxidation. Metal Science and Heat treatment, n. 6, p.538-540. 
- GRAHAM, M.J.; HUSSEY, R.J. (1987). Transport in growing oxide films. Oxidation of metals and associated mass transport. Conference, p.85-101.

- GRIMANELIS, D.; Eyre, T.S. (2007). Wear characteristics of a diffusion bonded sintered steel with short term surface treatments - Wear 262, p.93-103.

- HOBBS, L.W; MITCHELL T.E. (1983). Studies of metal oxidation by transmission electron microscopy. Int. Corros. Conf. Ser, High temperature corrosion conference, p.76-83.

- HOWE, C.I.; MCENANEY, B.; SCOTT, V.D. (1985). A new knetic model for nucleation and growth of duplex oxide scales on iron between 350 and 500 C. Corrosion Science 3, v.25, n.3, p.195-207.

- HUTCHING, I.M. (1992). Tribology: Friction and wear of Engineering Materials. CRC Press Inc., Boca Raton, USA, p.273.

- KENNETH, R.L. (1974). The Oxidation of metals. Rep.Prog.Phys., v.37, p. 231-316.

- KOFSTAD. (1983). Oxidation mechanism for pure metals in single oxidant gases. Int Corros Conf Ser, High temperature corrosion conference, p.123-138.

- LIM, S.C.; ASHBY, M.F. (1987). Wear-Mechanisms Maps", Acta Metallurgica, v.35, n.1, p.1-24.

- MEHL, R.F.; MCCANDLESS E. L. (1937). Oxide Films on Iron. New York Meeting, p.531-539.

- MELLO, J.D.B; BINDER, R.; KLEIN, A.N.; HUTCHINGS, I.M. (2001). Effect of compaction pressure on microstructure and hardness of steam oxidised sintered iron. Power Metallurgy, v.44, n.1. 
- METALS HANDBOOK: Powder Metal Technologies and Applications, 1998, v.7, ASM International, Metals Park, Ohio, USA, p.1146.

- MOLINARI, A.; STRAFELLINI, G. (1998). Quality control of steam treated sintered iron: importance of oxide characterization. Surface Engineering, v.14, n. 4, p.331-333.

- MOLINARI, A.; STRAFFELINI, G. (1995). - Surface durability of steam treated sintered iron alloys. Wear 181,183,334,341.

- NUNES, E. (2005). Cinética de oxidação a vapor de peças sinterizadas de ferro em um forno continúo. Dissertação (Mestrado) - Escola Politécnica da Universidade de São Paulo, São Paulo, 2005.

- PEASE III, L.F.; COlletTe, P.; PEASE, D.A. (1988). Mechanical Properties of steam blackened PM materials. Modern Development Powder Metallurgy, MPIF/APMI, v.21, p.275-299.

- PFEIL, L.B. (1929). The oxidation of iron and steel at high temperatures. p.501-560.

- RAZAVIZADEH, K.; DAVIES, B.L. (1979). Influence of powder type and density on pore closure and surface hardness changes resulting from steam treatment of sintered iron. Powder Metallurgy, n.4.

- RAZAVIZADEH, K.; DAVIES, B.L. (1981). The effects of steam treatment on the wear resistance of sintered iron and Fe-Cu allow. Wear 69, p.355-367.

- RICKERBY, D.S.; MATTHEWS, A. (1991). Advanced surface coatings: A Handbook of surface Engineering, Blackie \& Limited, Glasgow, Scotland, p.368. 
- RUTHEFORD, K.L.; HUTCHINGS, I.M. (1996). A micro-abrasive wear test, with particular application to coated systems. Surface and Coatings Technology 79, p.231-239.

- SAUNDERS, S.R.J.; NICHOLLS, J.R. (1998). Oxidation, hot corrosion and protection, Cap.14, p.1296-1336.

- STRAFFELINI, G.; MOLINARI, A. (1992). Dry sliding behavior of steam treatment iron alloys. Wear (Switzerland), v.159, n.1, p.127-134.

- WANG, J.; DANNINGER, H. (1998). Dry slinding wear behavior of molybdenum alloy sintered steels. Wear, v.222, p. 49-56.

- WANG, WEN-FUNG. (2007). Effect of powder type and compaction pressure on the density, hardness and oxidation resistance of sintered and steam-treated steels. Journal of materials Engineering and Performance, v.16, n.5, p.533-538.

- WILLIAM, J.A. (1999). Wear Modelling: Analytical, Computational an Mapping: a continuum mechanics approach. Wear, v.225-227, p.1-17.

- YOUNG, J.F.; SHANE, R.S. (1985). Materials and Processes. Part B: Processes, Marcel Dekker, Inc., 3.ed., p.1626 